
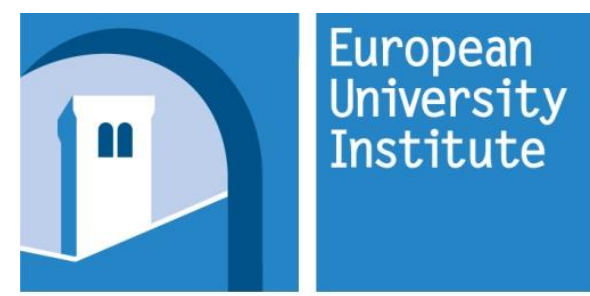

ROBERT

SCHUMAN

CENTRE FOR

ADVANCED

STUDIES

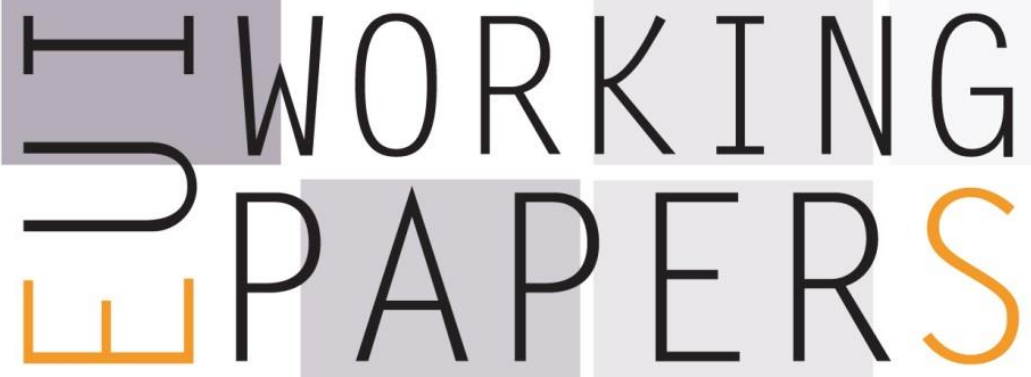

RSCAS 2015/26

Robert Schuman Centre for Advanced Studies Global Governance Programme-166

Scarcity, Size and Productivity Advantage of Foreign Affiliates with Intra-Firm Trade

Sotiris Blanas and Adnan Seric 

European University Institute

Robert Schuman Centre for Advanced Studies

Global Governance Programme

Scarcity, Size and Productivity Advantage of Foreign Affiliates with Intra-Firm Trade

Sotiris Blanas and Adnan Seric

EUI Working Paper RSCAS 2015/26 
This text may be downloaded only for personal research purposes. Additional reproduction for other purposes, whether in hard copies or electronically, requires the consent of the author(s), editor(s). If cited or quoted, reference should be made to the full name of the author(s), editor(s), the title, the working paper, or other series, the year and the publisher.

ISSN 1028-3625

(c) Sotiris Blanas and Adnan Seric, 2015

Printed in Italy, April 2015

European University Institute

Badia Fiesolana

I - 50014 San Domenico di Fiesole (FI)

Italy

www.eui.eu/RSCAS/Publications/

www.eui.eu

cadmus.eui.eu 


\section{Robert Schuman Centre for Advanced Studies}

The Robert Schuman Centre for Advanced Studies (RSCAS), created in 1992 and directed by Professor Brigid Laffan, aims to develop inter-disciplinary and comparative research on the major issues facing the process of European integration, European societies and Europe's place in $21^{\text {st }}$ century global politics.

The Centre is home to a large post-doctoral programme and hosts major research programmes, projects and data sets, in addition to a range of working groups and ad hoc initiatives. The research agenda is organised around a set of core themes and is continuously evolving, reflecting the changing agenda of European integration, the expanding membership of the European Union, developments in Europe's neighbourhood and the wider world.

Details of the research of the Centre can be found on:

http://www.eui.eu/RSCAS/Research/

Research publications take the form of Working Papers, Policy Papers, and e-books. Most of these are also available on the RSCAS website:

http://www.eui.eu/RSCAS/Publications/

The EUI and the RSCAS are not responsible for the opinions expressed by the author(s).

\section{The Global Governance Programme at the EUI}

The Global Governance Programme (GGP) is research turned into action. It provides a European setting to conduct research at the highest level and promote synergies between the worlds of research and policy-making, to generate ideas and identify creative and innovative solutions to global challenges.

The GGP comprises three core dimensions: research, policy and training. Diverse global governance issues are investigated in research strands and projects coordinated by senior scholars, both from the EUI and from other internationally recognized top institutions. The policy dimension is developed throughout the programme, but is highlighted in the GGP High-Level Policy Seminars, which bring together policy-makers and academics at the highest level to discuss issues of current global importance.The Academy of Global Governance (AGG) is a unique executive training programme where theory and "real world" experience meet. Young executives, policy makers, diplomats, officials, private sector professionals and junior academics, have the opportunity to meet, share views and debate with leading academics, top-level officials, heads of international organisations and senior executives, on topical issues relating to governance.

For more information:

http://globalgovernanceprogramme.eui.eu 



\title{
Scarcity, Size and Productivity Advantage of Foreign Affiliates with Intra-Firm Trade
}

\author{
Sotiris Blanas* Adnan Seric ${ }^{\dagger}$ \\ First draft: December 2013 \\ This draft: March 2015
}

\begin{abstract}
We juxtapose the main characteristics of 2403 foreign affiliates with and without intra-firm trade in 19 sub-Saharan-African countries in 2010. While intra-firm trade is scarce among foreign affiliates in the sample, arm's length trade is a very popular activity, even among those with intra-firm trade. The main distinguishing features of the average foreign affiliate with intra-firm trade are its larger size and higher productivity level. Its size premia range between $31.5 \%$ and $56.3 \%$ and its productivity premia between $25.4 \%$ and $30.7 \%$.
\end{abstract}

Keywords: foreign affiliates, intra-firm trade, complex FDI, sub-Saharan Africa, firm characteristics

JEL Classification: F14, F23, L21, L23, L24, L25

\footnotetext{
${ }^{*}$ Corresponding author: Université catholique de Louvain (IRES), address: Place Montesquieu 3, 1348, Louvain-la-Neuve, Belgium, e-mail: sotirios.blanas@uclouvain.be

${ }^{\dagger}$ United Nations Industrial Development Organisation (UNIDO), address: UNIDO Headquarter, 1400, Vienna, Austria, e-mail: a.seric@unido.org
} 



\section{Introduction $^{1}$}

Multinational Companies (henceforth MNCs) constitute the main locomotive in the current process of internationalisation of production and markets. This stylised fact has spawned numerous theoretical and empirical studies on different types of FDI (i.e., horizontal $^{2}$, vertical ${ }^{3}$, and export-platform ${ }^{4} \mathrm{FDI}$ ) and MNCs, as well as combinations of these (Carr et al., 2001; Grossman et al., 2006; Irarrazabal et al., 2013). UNCTAD (1998) is the first to report empirical evidence on such combinations. In addition, Feinberg and Keane (2001) study US MNCs with affiliates in Canada and find that only $12 \%$ of these are of purely horizontal type and only $19 \%$ of purely vertical. Thus, terms such as "complex integration strategies" and "complex FDI" have been coined (UNCTAD, 1998; Yeaple, 2003a; Helpman, 2006).

Despite the latest evidence, we still have a very limited knowledge about the main features that distinguish foreign affiliates with intra-firm trade from those without. Hanson et al. (2001) are the first to examine imports of foreign affiliates from their US parent companies by using a measure of affiliate size. Ramondo et al. (2011), with the use of the BEA data on roughly the whole population of foreign affiliates of US MNCs, find that intra-firm trade is concentrated among a small number of relatively large foreign affiliates, while the median foreign affiliate, which is smaller in size, reports no shipments to its parent and directs the bulk of its sales to non-affiliated parties in the host country. The main objective of this paper is to shed more light on the main firm characteristics that discern foreign affiliates with intra-firm trade from those without.

To this purpose, by employing data from the UNIDO Africa Investor Survey 2010 we juxtapose the main characteristics of 2403 foreign affiliates with and without intrafirm trade located in 19 countries in sub-Saharan Africa (SSA) in 2010. Their parent companies are based either in high-income, or non-SSA low/middle-income, or SSA countries. In contrast to the vast majority of previous theoretical and empirical studies which take into consideration only the manufacturing sector, this study covers all three main sectors of the economy (i.e., primary, secondary, and tertiary).

Given the well-documented rise in MNC activity in Africa and especially, in subSaharan Africa, our findings can prove to be very useful for policy makers in host

\footnotetext{
${ }^{1}$ We thank audiences at the UCLouvain IEG seminar, the UCLouvain DW May 2014, the ITSG July 2014, the ETSG 2014, the XIX DEGIT 2014, the KUL CoE ISS Fall 2014, and the 8th FIW 2014 for their comments and suggestions. Special thanks are extended to Costas Arkolakis, Gabor Békés, Rosario Crinò, Giorgia Giovannetti, Amanda Jakobsson, Florian Mayneris, Mathieu Parenti, and Lucía Pérez-Villar. Sotiris Blanas gratefully acknowledges financial support from the Fonds de la Recherche Scientifique - FNRS. All errors are ours.

${ }^{2}$ The MNC serves the foreign market by setting up a foreign affiliate rather than through exports. In doing so, the production process of the parent company is replicated in the foreign affiliate. Among others, see Caves (1982), Markusen (1984), Brainard (1997), Helpman et al. (2004), Horstmann and Markusen (1992), Markusen and Venables (2000), Ramondo et al. (2013).

${ }^{3}$ The MNC takes advantage of international factor differentials by transferring part of its production process to countries where factor prices are lower (Helpman, 1984; Helpman and Krugman, 1985, Yeaple, 2003b and Yeaple, 2008). In this case, intra-firm trade is created, as has been observed by several recent empirical studies (Hanson et al., 2001; Hanson et al., 2005; Borga and Zeile, 2004; OECD, 2002; Alfaro and Charlton, 2009).

${ }^{4}$ An affiliate located in a foreign country is used as platform for serving other markets nearby via exports (Ekholm et al., 2007; Badinger and Egger, 2010).
} 
countries to implement such industrial, trade, investment and development policies so that their countries benefit the most from the presence of MNCs.

Africa and in particular, sub-Saharan Africa, still lag behind other developing regions like Asia and Latin America, regarding their FDI inflows and their participation in regional and global value chains (UNCTAD, 2013, p. 39). However, since FDI could be an essential source of finance for industrialisation of the region, Africa is increasingly tapping into it. According to UNCTAD and UNIDO (2011, p. 77), its FDI inflows increased from $\$ 2.8$ billion to $\$ 58.6$ billion between 1990 and 2009, while the share of FDI in gross fixed capital formation increased from $3.2 \%$ to $24.1 \%$ between 1990 and 2007. Although most of FDI inflows by value are concentrated in Mining, important investment activities have taken place in Manufacturing between 2003 and 2009. UNCTAD (2010b) reports that $41 \%$ of the total number of Greenfield investment projects in Africa were accounted for by the manufacturing sector.

Although developed countries account for the bulk of the FDI flows into Africa, non-African developing countries - especially Brazil, China, India, and Turkey - are increasingly important sources. Their share in total FDI inflows to Africa increased from an average of $17.7 \%$ during the period 1995 - 1999 to $20.8 \%$ over the period 2000 - 2008 (UNCTAD, 2010a, p. 81). According to the same study, FDI from nonAfrican developing countries is mostly in natural resources but there are significant investments in infrastructure, ${ }^{5}$ finance, agriculture and light manufacturing. UNCTAD (2013, p. 127) reports that there has also been a remarkable increase over the past decade in intra-African investment, with $68 \%$ of Greenfield investment being accounted for by the services sector.

As regards trade activity which is very closely linked to FDI, Africa has experienced a significant rise in total merchandise trade, from $\$ 7$ billion in 1995 to $\$ 86$ billion in 2008. This has been accompanied by increasing trade with other non-African developing countries. Also, its share of global trade rose from $2.2 \%$ in 2000 to $3.3 \%$ in 2008 (UNCTAD, 2010a, p. 29).

In line with Ramondo et al. (2011), the data analysis reveals that intra-firm trade is concentrated among a small number of firms. In particular, foreign affiliates with intra-firm trade account for only $21.9 \%$ of all firms in the sample. This is an essential stylised fact because it poses the critical question as to why firm boundaries exist if not for the transfer of physical goods. According to Atalay et al. (2014), the main reason for their existence is the transfer of intangibles. ${ }^{6}$

Interestingly, though, we find that the big majority of foreign affiliates do trade, but they mostly do so outside the boundaries of the firm (i.e., at arm's length). Roughly half of the total number of firms in the sample have only arm's length trade. Trade at arm's length is also a very popular activity even among foreign affiliates with intrafirm trade. These findings are important in two ways. First, they are indicative of

\footnotetext{
${ }^{5}$ Between 2001 and 2007, China's infrastructure finance commitment in sub-Saharan Africa rose from $\$ 470$ million to $\$ 4.5$ billion. Other countries with significant investments in infrastructure are India, Kuwait, Saudi Arabia, and the United Arab Emirates (UNCTAD, 2010b, p. 81; UNCTAD, 2010a).

${ }^{6}$ Many terms which are related to intangibles can be found in the literature: knowledge capital (Markusen, 1984), technology capital (McGrattan and Prescott, 2010), organisational capital (Garicano and Rossi-Hansberg, 2006), core capabilities (Bernard et al., 2012), managerial ability (Bloom and Van Reenen, 2007), capabilities (Atalay et al., 2014).
} 
the complexity that characterises import and export activities of foreign affiliates and justifies terms that have been coined in the literature, such as "complex" FDI. Second, it shows how opaque the firm boundaries remain despite the great progress that has been made in recent years both in theory (Antràs, 2003) and in empirics (Nunn and Trefler, 2013; Corcos et al., 2013). Unfortunately, in our data we do not observe firm-to-firm transactions by product and therefore, we cannot look into this issue further.

From the regression analysis we find that the main distinguishing firm characteristics of the average foreign affiliate with intra-firm are its greater size and higher productivity level. The first finding is in accord with Ramondo et al. (2011). We report size premia of $31.5 \%$ and $56.3 \%$ when proxied by the total number of employees and total sales, respectively. The productivity premia are $25.4 \%$ and $25.5 \%$ when productivity is proxied by the ratios of total sales and total value added to total employment. The estimated total factor productivity premia are $30.7 \%$.

After decomposing intra-firm trade into intra-firm imports, exports and both imports and exports, we find that a clear sorting pattern arises. On average, foreign affiliates with both intra-firm imports and exports seem to be the biggest and most productive firms, those with only intra-firm exports smaller and less productive, those with only intra-firm imports even smaller and less productive, while those with only arm's length trade are bigger and more productive only than those without intra-firm trade, which are the smallest and least productive firms. Reporting these premia becomes even more important after we show that foreign affiliates with only arm's length trade differ from domestic firms which engage in international trade in terms of size and productivity. They are bigger and more productive by $11.9 \%$ and $25.7 \%$, respectively. The sorting pattern can be easily explained theoretically based on the Melitz (2003) model of firm heterogeneity in which the fixed cost of arm's length trade is smaller than the fixed cost of intra-firm imports, which in turn, is smaller than the fixed cost of intra-firm exports.

We draw some novel and useful conclusions about the host-country effects of FDI based on the results that we obtain. The greater size of the average foreign affiliate with intra-firm trade can be translated into a greater number of job opportunities for local job-market seekers. In addition, any local firms which manage to develop linkages with this type of foreign affiliate may benefit by more from productivity spillovers due to its productivity advantage.

The remainder of this paper is as follows. In Section 2 we describe the data and report several stylised facts on the host countries, industries and parent locations of the two types of affiliates, different combinations of these, as well as, on their distributions by size and productivity. In Section 3 we present the benchmark econometric model, while in Section 4 the main empirical results, robustness checks and the estimated size and productivity premia. In Section 5 we provide a simple theoretical explanation for the self-selection of foreign affiliates into intra-firm trade based on the model of firm heterogeneity of Melitz (2003), while in Section 6 the main concluding remarks and suggestions for further research. 


\section{Data and stylised facts}

In this section we describe the main dataset to be employed in the econometric analysis and juxtapose foreign affiliates with and without intra-firm trade in terms of the host countries in which they are located and all possible combinations of the origin of their parent company and the industries in which they operate. We also provide statistics on the percentage of foreign affiliates with different types of trade flows (i.e., intra-firm and/or arm's length) and try to quantify any size and productivity premia of foreign affiliates with intra-firm trade.

\section{$2.1 \quad$ Data}

We draw all firm-level data from the UNIDO Africa Investor Survey 2010. The main aim of this survey is to collect information at the firm level directly from business owners and senior managers about their business and their assessment of the current business environment. It includes information about 2403 foreign affiliates in 19 sub-SaharanAfrican countries for the last financial year (i.e., 2009). All monetary variables are in national currencies and in order to convert these into US dollars (USD), we rely on the exchange rate data of the World Bank World Development Indicators (WDI).

As regards intra-firm trade, this is directly observed in the data and therefore, we do not need to construct ourselves any proxy for vertical relationship based on InputOutput (I-O) tables or disaggregated classifications of products/services produced in the parent and the foreign affiliate (Alfaro and Charlton, 2009). In particular, we claim that a foreign affiliate has intra-firm imports if its percentage of production inputs by value that was imported through the parent company is greater than 0 and less than or equal to 100. Similarly, a foreign affiliate has intra-firm exports if its percentage of direct exports by value is supplied to its parent and/or its sister affiliates is greater than 0 and less than or equal to 100. Consequently, a foreign affiliate with intra-firm trade is an entity that satisfies one of the two or both of the aforementioned conditions (i.e., the firm has either intra-firm imports, or intra-firm exports, or both).

\subsection{Foreign affiliates with and without intra-firm trade}

Table 1 portrays the 19 countries in sub-Saharan Africa where foreign affiliates with and without intra-firm trade are located. Among firms with inta-firm trade, the biggest number of these are based in Kenya, Uganda, Tanzania, Ghana and Cameroon (17.3\%, $16.2 \%, 8 \%, 5.9 \%$, and $5.7 \%$, respectively), while the smallest number in Niger $(0.8 \%)$, Burundi (1\%), Burkina Faso (1.1\%), Mali (2.5\%), and Malawi (2.7\%). Among firms without intra-firm trade, the biggest number of these are based in Uganda $(17.1 \%)$, Kenya (10.7\%), Ghana (8\%), Nigeria (6.3\%) and Mozambique (6.1\%), and the smallest number in Niger (1\%), Burkina Faso (1.2\%), Malawi (1.8\%), Burundi (2.2\%), Lesotho and Rwanda ( $2.9 \%$ each).

Foreign affiliates without intra-firm trade operate in more industries than those with intra-firm trade (56 industries Vs 41 industries). This is mostly driven by the absence of affiliates with intra-firm trade from many services industries. This is in line with Ramondo et al. (2011) who find that intra-firm trade occurs primarily in goods, rather 
than services. Among affiliates with intra-firm trade, the highest percentages of these are to be found in industries with ISIC 15 (11.8\%), 25 (8.6\%), 1 (8.4\%), 24 and 51 (8.2\% each), 18 (7.6\%), $52(6.3 \%)$, and 45 (5.1\%), while the lowest in industries with ISIC 2, $33,41,63,71,72$, and $92(0.2 \%$ each $)$. Among affiliates without intra-firm trade, the highest percentages of these operate in industries with ISIC 15 (8.4\%), 51 (6.7\%), 74 (5.6\%), 45 (5.4\%), 25 and 55 (5.2\% each), 65 (5.1\%), and 28 (4.9\%), while the lowest in industries with ISIC 12, 30, 73, 85, and 93 ( $0.1 \%$ each). To save on space, we relegate to the Appendix the tables with the industries by type of foreign affiliate.

Table 1: Locations of foreign affiliates with and without intra-firm trade

\begin{tabular}{|c|c|c|c|c|c|}
\hline \multirow[b]{2}{*}{ Name } & \multirow[b]{2}{*}{ Code } & \multicolumn{2}{|c|}{ with intra-firm trade } & \multicolumn{2}{|c|}{ without intra-firm trade } \\
\hline & & \# of firms & $\%$ of firms & \# of firms & $\%$ of firms \\
\hline Burundi & BDI & 5 & 1 & 41 & 2.2 \\
\hline Burkina Faso & BFA & 6 & 1.1 & 23 & 1.2 \\
\hline Cameroon & CMR & 30 & 5.7 & 103 & 5.5 \\
\hline Cape Verde & CPV & 22 & 4.2 & 82 & 4.4 \\
\hline Ethiopia & ETH & 24 & 4.6 & 109 & 5.8 \\
\hline Ghana & GHA & 31 & 5.9 & 151 & 8 \\
\hline Kenya & KEN & 91 & 17.3 & 200 & 10.7 \\
\hline Lesotho & LSO & 22 & 4.2 & 54 & 2.9 \\
\hline Madagascar & MDG & 27 & 5.1 & 96 & 5.1 \\
\hline Mali & MLI & 13 & 2.5 & 78 & 4.2 \\
\hline Mozambique & MOZ & 16 & 3 & 114 & 6.1 \\
\hline Malawi & MWI & 14 & 2.7 & 34 & 1.8 \\
\hline Niger & NER & 4 & 0.8 & 18 & 1 \\
\hline Nigeria & NGA & 30 & 5.7 & 119 & 6.3 \\
\hline Rwanda & RWA & 18 & 3.4 & 55 & 2.9 \\
\hline Senegal & SEN & 23 & 4.4 & 87 & 4.6 \\
\hline Tanzania & TZA & 42 & 8 & 113 & 6 \\
\hline Uganda & UGA & 85 & 16.2 & 321 & 17.1 \\
\hline \multirow[t]{2}{*}{ Zambia } & $\mathrm{ZMB}$ & 23 & 4.4 & 79 & 4.2 \\
\hline & Total & 526 & 100 & 1877 & 100 \\
\hline
\end{tabular}

As for the parent locations, parents of the highest percentage of affiliates with intrafirm trade are located in India (10\%), South Africa (9.5\%), France and the United Kingdom (8.7\% each), Kenya (6.9\%), the US (4.8\%), China and the Netherlands $(4.1 \%$ each), Portugal (3.7\%), Lebanon and Mauritius (2.5\% each), Germany and Switzerland (2.5\%), Hong Kong and Taiwan (1.9\%), Italy (1.7\%), Japan (1.5\%), Denmark, Spain and the United Arab Emirates (1.4\%), Belgium, Senegal, Uganda and Tanzania (1\%). Parents of the highest percentage of affiliates without intra-firm trade are located in India (14\%), France (9.8\%), the United Kingdom (9.7\%), South Africa (6.3\%), China and Kenya (6\% each), Portugal (4.4\%), Italy (4\%), Lebanon (3.9\%), the US $(3.6 \%)$, the Netherlands (2.1\%), Switzerland (1.8\%), Mauritius (1.7\%), Germany (1.6\%), Canada $(1.2 \%)$, and Belgium (0.9\%).

Table 2 reports the number of firms with and without intra-firm trade by sector and parent location. Regarding sectors, we consider the whole economy (ISIC between 1 and 99), Agriculture (ISIC between 1 and 5), Mining (ISIC between 10 and 14), Manufacturing (ISIC between 15 and 39), Resource-based manufacturing (ISIC: 15, 16, 20, 21, 23, 25, 26, 27), Low-tech manufacturing (ISIC: 17, 18, 19, 22, 28, 36), Medium/High-tech manufacturing (ISIC: 24, 29, 30, 31, 32, 33, 34, 35, 37, 38), 
Electricity, gas and water supply (EGW supply) and Construction (ISIC 40 and 45, respectively), and Services (ISIC between 50 and 99). We distinguish between three different types of parent location based on the income level of the country in which the parent company is situated (i.e., high-income countries (HI), low/middle-income excluding sub-Saharan-African ones (LMI), and those in sub-Saharan Africa (SSA)). In order to classify each parent location by the level of income we rely upon the World Bank Historical Country Classification for the year 2010. Low/middle-income countries are those which are classified by the World Bank for the corresponding year as either low-income, or lower-middle-income, or upper-middle-income.

For the whole economy, the parent firms of the highest percentage of affiliates with intra-firm trade are located in high-income countries, of the second highest in low/middle-income countries, while those of the lowest in sub-Saharan Africa $(52.4 \%$, $33.4 \%$, and $14.2 \%$, respectively). This is also true for Agriculture (74.5\%, $12.8 \%$, $12.8 \%$, respectively), Mining $(53.3 \%, 46.7 \%, 0 \%$, respectively), Manufacturing $(50.6 \%$, $36.3 \%, 13.1 \%$, respectively), Resource-based manufacturing $(52.3 \%, 31.5 \%, 16.1 \%$, respectively), Medium/High-tech manufacturing (66.7\%, 22.2\%, 11.1\%, respectively), EGW supply and Construction $(50 \%, 35.7 \%, 14.3 \%$, respectively), and Services $(47.9 \%$, $31.3 \%, 20.8 \%$, respectively). The only exception is the low-tech manufacturing sector in which the parents of the highest percentage of foreign affiliates with intra-firm trade are based in low/middle-income countries $(36.4 \%, 53.5 \%$, and $10.1 \%$, respectively).

As far as foreign affiliates without intra-firm trade are concerned, the parents of the smallest percentage of these are located in sub-Saharan Africa. This holds for the whole economy and for any other sector examined. The differences in the percentages of affiliates whose parents are located in high- and non-SSA low/middle-income countries are much smaller than before (Whole economy: 49.4\% Vs 37\%, Manufacturing: 44.9\% Vs 43.3\%, Resource-based manufacturing: 43.9\% Vs 43.4\%, Medium/High-tech manufacturing: $47.8 \%$ Vs $40.8 \%$ ) or even vanished (Low-tech manufacturing: $44.8 \%$ Vs $44.8 \%)$. Sectors for which there are still quite big differences are: Agriculture $(60.7 \%$ Vs $21.3 \%$ ), Mining (58.8\% Vs 41.2\%), EGW supply and Construction (56\% Vs 35.8\%) and Services (51.5\% Vs 32.1\%).

Panel A in Table 3 reveals that intra-firm trade is a relatively rare activity. Only 526 out of the 2403 foreign affiliates (21.9\% of the total) trade with their parent company (i.e., they have either intra-firm imports or intra-firm exports, or both). The rest 1877 (78.1\% of the total) do not have any intra-firm trade flows. Among the firms with intra-firm trade, $77.8 \%$ of these have intra-firm imports (Panel B), 39.4\% have intrafirm exports (Panel C), 17.1\% have both intra-firm imports and exports (Panel D), $60.6 \%$ have only intra-firm imports (Panel E), while $22.2 \%$ have only intra-firm exports (Panel F). 
Table 2: Foreign investors' origin

\begin{tabular}{|c|c|c|c|c|}
\hline \multirow[b]{2}{*}{ Parent location } & \multicolumn{2}{|c|}{ " with intra-firm trade } & \multicolumn{2}{|c|}{ without intra-firm trade } \\
\hline & \multicolumn{4}{|c|}{ Whole economy } \\
\hline High-income country & 265 & 52.4 & 871 & 49.4 \\
\hline Low/middle-income country & 169 & 33.4 & 653 & 37 \\
\hline sub-Saharan African country & 72 & 14.2 & 240 & 13.6 \\
\hline \multirow[t]{2}{*}{ Total } & 506 & 100 & 1764 & 100 \\
\hline & \multicolumn{4}{|c|}{ Agriculture } \\
\hline High-income country & 35 & 74.5 & 37 & 60.7 \\
\hline Low/middle-income country & 6 & 12.8 & 13 & 21.3 \\
\hline sub-Saharan African country & 6 & 12.8 & 11 & 18 \\
\hline \multirow[t]{2}{*}{ Total } & 47 & 100 & 61 & 100 \\
\hline & \multicolumn{4}{|c|}{ Mining } \\
\hline High-income country & 8 & 53.3 & 20 & 58.8 \\
\hline Low/middle-income country & 7 & 46.7 & 14 & 41.2 \\
\hline sub-Saharan African country & 0 & 0 & 0 & 0 \\
\hline \multirow[t]{2}{*}{ Total } & 15 & 100 & 34 & 100 \\
\hline & \multicolumn{4}{|c|}{ Manufacturing } \\
\hline High-income country & 162 & 50.6 & 347 & 44.9 \\
\hline Low/middle-income country & 116 & 36.3 & 334 & 43.3 \\
\hline sub-Saharan African country & 42 & 13.1 & 91 & 11.8 \\
\hline \multirow[t]{2}{*}{ Total } & 320 & 100 & 772 & 100 \\
\hline & \multicolumn{4}{|c|}{ Resource-based manufacturing } \\
\hline High-income country & 78 & 52.3 & 165 & 43.9 \\
\hline Low/middle-income country & 47 & 31.5 & 163 & 43.4 \\
\hline African country & 24 & 16.1 & 48 & 12.8 \\
\hline \multirow[t]{2}{*}{ Total } & 149 & 100 & 376 & 100 \\
\hline & \multicolumn{4}{|c|}{ Low-tech manufacturing } \\
\hline High-income country & 36 & 36.4 & 107 & 44.8 \\
\hline country & 53 & 53.5 & 107 & 44.8 \\
\hline frican country & 10 & 10.1 & 25 & 10.5 \\
\hline \multirow{2}{*}{ Total } & 99 & 100 & 239 & 100 \\
\hline & \multicolumn{4}{|c|}{ Medium/High-tech manufacturing } \\
\hline High-income country & 48 & 66.7 & 75 & 47.8 \\
\hline ddle-income country & 16 & 22.2 & 64 & 40.8 \\
\hline country & 8 & 11.1 & 18 & 11.5 \\
\hline \multirow[t]{2}{*}{ Total } & 72 & 100 & 157 & 100 \\
\hline & \multicolumn{4}{|c|}{ EGW supply/Construction } \\
\hline High-i & 14 & 50 & 61 & 56 \\
\hline ncome country & 10 & 35.7 & 39 & 35.8 \\
\hline aran African country & 4 & 14.3 & 9 & 8.3 \\
\hline \multirow[t]{2}{*}{ Total } & 28 & 100 & 109 & 100 \\
\hline & \multicolumn{4}{|c|}{ Services } \\
\hline High-income country & 46 & 47.9 & 406 & 51.5 \\
\hline Low/middle-income country & 30 & 31.3 & 253 & 32.1 \\
\hline sub-Saharan African country & 20 & 20.8 & 129 & 16.4 \\
\hline Total & 96 & 100 & 788 & 100 \\
\hline \multicolumn{5}{|c|}{$\begin{array}{l}\text { Notes: Authors' calculations. Firms with intra-firm trade are those with either intra-firm imports, or intra- } \\
\text { firm exports or both. Resource-based manufacturing industry codes: } 15,16,20,21,23,25,26,27 . \text { Low-tech } \\
\text { manufacturing industry codes: }\end{array}$} \\
\hline
\end{tabular}


Table 3: Foreign affiliates with and without intra-firm trade

\begin{tabular}{lcc}
\hline \hline Panel A: With intra-firm trade & \# of firms & \% of firms \\
No & 1877 & 78.1 \\
Yes & 526 & 21.9 \\
Total & 2403 & 100 \\
\hline Panel B: With intra-firm imports & $\#$ of firms & $\%$ of firms \\
No & 117 & 22.2 \\
Yes & 409 & 77.8 \\
Total & 526 & 100 \\
\hline Panel C: With intra-firm exports & $\#$ of firms & $\%$ of firms \\
No & 319 & 60.6 \\
Yes & 207 & 39.4 \\
Total & 526 & 100 \\
\hline Panel D: With both intra-firm imports and exports & $\#$ of firms & $\%$ of firms \\
No & 436 & 82.9 \\
Yes & 90 & 17.1 \\
Total & 526 & 100 \\
\hline Panel E: With intra-firm imports only & $\#$ of firms & $\%$ of firms \\
No & 207 & 39.4 \\
Yes & 319 & 60.6 \\
Total & 526 & 100 \\
\hline Panel F: With intra-firm exports only & \# of firms & $\%$ of firms \\
No & 409 & 77.8 \\
Yes & 117 & 22.2 \\
Total & 526 & 100 \\
\hline Notes: Authors' calculations. Firms with intra-firm trade are those with either intra-firm imports, or intra- \\
form exports or both. & & \\
Source: UNIDO Africa Investor Survey 2010. & &
\end{tabular}

Table 4: Foreign affiliates with different types of trade

\begin{tabular}{lcc}
\hline \hline Panel A: With trade & \# of firms & \% of firms \\
No & 660 & 27.5 \\
Yes & 1743 & 72.5 \\
Total & 2403 & 100 \\
\hline Panel B: With 100\% arms' length trade & $\#$ of firms & $\%$ of firms \\
No & 1186 & 49.4 \\
Yes & 1217 & 50.6 \\
Total & 2403 & 100 \\
\hline Panel C: With 100\% intra-firm trade & $\#$ of firms & $\%$ of firms \\
No & 2226 & 92.6 \\
Yes & 177 & 7.4 \\
Total & 2403 & 100 \\
\hline Panel D: With both intra-firm and arms' length trade & $\#$ of firms & $\%$ of firms \\
No & 2054 & 85.48 \\
Yes & 349 & 14.52 \\
Total & 2403 & 100.00 \\
\hline Notes: Authors' calculations. Firms with trade are those with either imports, or exports or both. \\
Source: UNIDO Africa Investor Survey 2010.
\end{tabular}

The fact that most of the foreign affiliates in our sample do not engage in intra-firm trade does not mean that they do not trade at all. They do trade, but they only do so outside the boundaries of the firm (i.e., at arm's length), as shown in Table 4. According to Panel A, 1743 out of 2403 foreign affiliates (72.5\% of the total) have either type of trade (i.e., either intra-firm or arms' length) and according to Panel B, 1217 or 50.6\% of the total trade only at arms' length. Panels $\mathrm{C}$ and $\mathrm{D}$ reveal that arms' length trade is a popular activity also among foreign affiliates with intra-firm trade. Only 177 out of the 526 have only intra-firm trade, the rest 349 have a combination of both. 
As shown in Table 5, among the 1743 foreign affiliates which have any of the two types of trade, $88.4 \%$ of these are importers (i.e., either intra-firm importers, or arms' length importers, or both) (Panel A), 48.9\% are exporters (i.e., either intra-firm exporters, or arms' length exporters, or both) (Panel B), 37.3\% are both importers and exporters (Panel C), 51.1\% are only importers (Panel D), and 11.6\% are only exporters (Panel E).

Table 6 shows that among the 1540 importers, $73.4 \%$ of these import only at arms' length (Panel A), while 9.2\% only intra-firm (Panel B). For the 853 exporters, I show that $75.7 \%$ of these export only at arms' length (Panel C), while $6.2 \%$ only intra-firm (Panel D). The vast majority of the 650 importers-exporters trade only at arms' length $(86.2 \%)$ (Panel E). Only 17\% of these import and export only from and to their parent and/or other affiliated parties (Panel F).

Table 5: Foreign affiliates with and without trade

\begin{tabular}{lcc}
\hline \hline Panel A: With imports & \# of firms & \% of firms \\
No & 203 & 11.6 \\
Yes & 1540 & 88.4 \\
Total & 1743 & 100 \\
\hline Panel B: With exports & \# of firms & $\%$ of firms \\
No & 890 & 51.1 \\
Yes & 853 & 48.9 \\
Total & 1743 & 100 \\
\hline Panel C: With both imports and exports & \# of firms & $\%$ of firms \\
No & 1093 & 62.7 \\
Yes & 650 & 37.3 \\
Total & 1743 & 100 \\
\hline Panel D: With imports only & $\#$ of firms & $\%$ of firms \\
No & 853 & 48.9 \\
Yes & 890 & 51.1 \\
Total & 1743 & 100 \\
\hline Panel E: With exports only & $\#$ of firms & $\%$ of firms \\
No & 1540 & 88.4 \\
Yes & 203 & 11.6 \\
Total & 1743 & 100 \\
\hline Notes: Authors' calculations. Imports and exports are either intra-firm or arms' length or \\
both. \\
Source: UNIDO Africa Investor Survey 2010. & &
\end{tabular}

In Table 7 we provide evidence on foreign affiliates with various combinations of intra-firm and arms' length trade flows. We show that $15.4 \%$ of the 1743 foreign affiliates with trade have both intra-firm and arms' length imports, $8.8 \%$ have both intra-firm and arms' length exports, $4.2 \%$ have intra-firm and arms' length imports and exports, $6.4 \%$ have intra-firm imports and only arms' length exports, $4.6 \%$ have intra-firm exports and only arms' length imports, 4.5\% have intra-firm and arms' length imports and only arms' length exports, 3.8\% have intra-firm and arms' length exports and only arms' length imports, 3.8\% have intra-firm and arms' length imports and intra-firm exports, 3.4\% have intra-firm and arms' length exports and intra-firm imports, $0.7 \%$ have intra-firm and arms' length imports and only intra-firm exports, and finally, $0.4 \%$ have intra-firm and arms' length exports and only intra-firm imports. We also produce the tables for those with intra-firm and/or arms' length trade, for those which trade only at arms' length, as well as for those which trade only intra-firm by sector and by sector-parent location pairs. The tables reveal a salient heterogeneity across sectors and 
across sector-parent location pairs. Foreign affiliates which trade only at arms' length are the majority in all sectors and for almost all sector-parent location pairs.

Table 6: Foreign affiliates with 100\% arms' length trade and 100\% intra-firm trade

\begin{tabular}{lcc}
\hline \hline Panel A: With 100\% arms' length imports & \# of firms & $\%$ of firms \\
No & 409 & 26.6 \\
Yes & 1131 & 73.4 \\
Total & 1540 & 100 \\
\hline Panel B: With 100\% intra-firm imports & $\#$ of firms & $\%$ of firms \\
No & 1399 & 90.8 \\
Yes & 141 & 9.2 \\
Total & 1540 & 100 \\
\hline Panel C: With 100\% arms' length exports & $\#$ of firms & $\%$ of firms \\
No & 207 & 24.3 \\
Yes & 646 & 75.7 \\
Total & 853 & 100 \\
\hline Panel D: With 100\% intra-firm exports & $\#$ of firms & $\%$ of firms \\
No & 800 & 93.8 \\
Yes & 53 & 6.2 \\
Total & 853 & 100 \\
\hline Panel E: With both 100\% arms' length imports and exports & $\#$ of firms & $\%$ of firms \\
No & 90 & 13.8 \\
Yes & 560 & 86.2 \\
Total & 650 & 100 \\
\hline Panel F: With both 100\% intra-firm imports and exports & \# of firms & $\%$ of firms \\
No & 633 & 97.4 \\
Yes & 17 & 2.6 \\
Total & 650 & 100 \\
\hline Notes: Authors' calculations. Panel A: Firms whose 100\% of imports are at arms' length. Panel B: Firms whose $100 \%$ of \\
imports are intra-firm. Panel C: Firms whose 100\% of exports are at arms' length. Panel D: Firms whose 100\% of exports \\
are intra-firm. Panel E: Firms whose 100\% of imports and 100\% of exports are at arms' length. Panel F: Firms whose \\
100\% of imports and 100\% of exports are intra-firm. & & \\
Source: UNIDO Africa Investor Survey 2010. & & \\
& &
\end{tabular}

In sum, although most of the foreign affiliates in our sample engage in trade activities, they do so mostly at arms' length. Arm's length trade is a popular activity even among foreign affiliates with intra-firm trade. By contrast, intra-firm trade is scarce.

Despite the great progress that has been made in recent years both in theory (Antràs, 2003) and in empirics (Nunn and Trefler, 2013; Corcos et al., 2013) on the determinants of firm boundaries, the fact that most of the foreign affiliates in our sample, even those with intra-firm trade, engage in trade with unaffiliated parties, calls for further investigation of this issue. Unfortunately, the data available to us lack firm-to-firm transactions by product and therefore, we cannot look into this issue.

What is more, the scarcity of intra-firm trade makes one wonder as to why firm boundaries exist, if not for the transfer of physical goods. Atalay et al. (2014) argue that the primary reason for the existence of firm boundaries is the transfer of intangibles, rather than tangible goods. Hence, they imply that intangibles, when transferred through the market, are subject to the same inefficiencies as physical goods (Grossman and Hart, 1986; Hart and Moore, 1990; Antràs, 2003) and that these inefficiencies are mitigated when they are transferred within the firm boundaries. ${ }^{7}$

\footnotetext{
${ }^{7}$ According to the Property Rights Theory (PRT), the firm boundaries ensure that the owner has residual rights of control over relationship-specific assets.
} 
Table 7: Foreign affiliates with combinations of intra-firm and arms' length trade

\begin{tabular}{|c|c|c|}
\hline Panel A: With intra-firm and arms' length imports & \# of firms & $\%$ of firms \\
\hline No & 1475 & 84.6 \\
\hline Yes & 268 & 15.4 \\
\hline Total & 1743 & 100 \\
\hline Panel B: With intra-firm and arms' length exports & \# of firms & $\%$ of firms \\
\hline No & 1589 & 91.2 \\
\hline Yes & 154 & 8.8 \\
\hline Total & 1743 & 100 \\
\hline Panel C: With intra-firm and arms' length imports and exports & \# of firms & \% of firms \\
\hline No & 1670 & 95.8 \\
\hline Yes & 73 & 4.2 \\
\hline Total & 1743 & 100 \\
\hline Panel D: With intra-firm imports and arms' length exports & \# of firms & $\%$ of firms \\
\hline No & 1632 & 93.6 \\
\hline Yes & 111 & 6.4 \\
\hline Total & 1743 & 100 \\
\hline Panel E: With intra-firm exports and arms' length imports & \# of firms & $\%$ of firms \\
\hline No & 1663 & 95.4 \\
\hline Yes & 80 & 4.6 \\
\hline Total & 1743 & 100 \\
\hline Panel F: With intra-firm and arms' length imports and arms' length exports & \# of firms & $\%$ of firms \\
\hline No & 1665 & 95.5 \\
\hline Yes & 78 & 4.5 \\
\hline Total & 1743 & 100 \\
\hline Panel G: With intra-firm and arms' length exports and arms' length imports & \# of firms & $\%$ of firms \\
\hline No & 1677 & 96.2 \\
\hline Yes & 66 & 3.8 \\
\hline Total & 1743 & 100 \\
\hline Panel H: With intra-firm and arms' length imports and intra-firm exports & \# of firms & $\%$ of firms \\
\hline No & 1677 & 96.2 \\
\hline Yes & 66 & 3.8 \\
\hline Total & 1743 & 100 \\
\hline Panel I: With intra-firm and arms' length exports and intra-firm imports & \# of firms & $\%$ of firms \\
\hline No & 1683 & 96.6 \\
\hline Yes & 60 & 3.4 \\
\hline Total & 1743 & 100 \\
\hline Panel J: With intra-firm and arms' length imports and $100 \%$ intra-firm exports & \# of firms & $\%$ of firms \\
\hline No & 1730 & 99.3 \\
\hline Yes & 13 & 0.7 \\
\hline Total & 1743 & 100 \\
\hline Panel K: With intra-firm and arms' length exports and $100 \%$ intra-firm imports & \# of firms & $\%$ of firms \\
\hline No & 1736 & 99.6 \\
\hline Yes & 7 & 0.4 \\
\hline Total & 1743 & 100 \\
\hline
\end{tabular}

Table 8 displays the same statistics as in Table 3 by sector and parent location. In terms of sectors, the highest percentage of foreign affiliates with intra-firm trade operate in Agriculture (43\%), Mining (32.7\%), and Manufacturing (28.8\%), while the lowest percentage in Services (10.7\%) and EGW supply and Construction (19.3\%). Within manufacturing, the percentage of the same type of affiliate in resource-based industries is a bit smaller than the whole sector $(27.7 \%)$, that in low-tech industries almost identical $(28.7 \%)$, and that in medium/high-tech industries slightly bigger (31.4\%). In Panel A.1, the percentages of foreign affiliates with intra-firm trade whose parents are located in high-income countries are bigger than before in Agriculture (48.6\%), Manufacturing (31.8\%), and in particular, in Resource-based manufacturing (32.1\%) and Medium/High-tech manufacturing (39\%). Instead, they are smaller in Mining (28.6\%) 
and Low-tech manufacturing (25.2\%), and only slightly smaller in EGW supply and Construction (18.7\%) and Services (10.2\%).

The pattern is a bit different for foreign affiliates whose parents are located in nonSSA low/middle-income countries and in SSA countries (Panel A.2 and Panel A.3). The percentages for the first, as compared to those in Panel A, are higher in Mining (33.3\%), Low-tech manufacturing (33.1\%), and EGW supply and Construction (20.4\%), while lower or roughly equal in Agriculture (31.6\%), Manufacturing (25.8\%), Resource-based and Medium/High-tech manufacturing (22.4\% and 20\%, respectively), and in Services $(10.6 \%)$. The percentages for the second are smaller or roughly equal in Agriculture (35.3\%), and in Low-tech and Medium/High-tech manufacturing (28.6\% and 30.8\%, respectively), while bigger in Manufacturing (31.6\%), Resource-based manufacturing (33.3\%), EGW supply and Construction (30.8\%), and Services (13.4\%). There are no foreign investors from sub-Saharan Africa with foreign affiliates in Mining.

Panel B shows that among firms with intra-firm trade, the highest percentages of those with intra-firm imports operate in Services (99\%), EGW supply and Construction (96.4\%), Mining (88.2\%), Low-tech manufacturing (82.5\%), Medium/High-tech manufacturing (76.3\%), Manufacturing (73.2\%), while the lowest in Agriculture (51\%) and Resource-based manufacturing (65.4\%). Panels B.1-B.3 reveal that the patterns for foreign affiliates with intra-firm imports whose parents are located in any of the three country types are very similar to the one in Panel B. The main differences are observed in Agriculture in which there is a smaller percentage of foreign affiliates with intra-firm imports whose parents are located in high-income countries (42.9\%), while a higher percentage of those whose parents are located in non-SSA low/middle-income and SSA countries (66.7\% and $83.3 \%$, respectively). In addition, while the percentage of firms with intra-firm imports whose parents are located in non-SSA low/middle-income countries is higher in Medium/High-tech manufacturing (87.5\%), that of firms whose parents are located in SSA countries is much smaller $(62.5 \%)$.

According to Panel $\mathrm{C}$, the highest percentages of foreign affiliates with intra-firm exports are found in Agriculture (73.5\%), Mining (52.9\%), and Resource-based manufacturing (52.3\%), while the lowest ones in Services $(2 \%)$ and in EGW supply and Construction (7.1\%). Panels C.1 to C.3 reveal that the percentage of firms with intrafirm exports whose parents are located in high-income countries is higher than the one in Panel $\mathrm{C}$ in all industries except for Medium/High-tech manufacturing $(37.5 \% \mathrm{Vs}$ $38.2 \%$ ), while the percentages of firms whose parents are located in non-SSA low/middleincome countries and SSA countries are lower in all industries except for Low-tech and Medium/High-tech manufacturing (Panel C.2: $50.9 \%$ Vs $47.6 \%$ and $43.8 \%$ Vs $38.2 \%$, respectively) and for EGW supply and Construction (Panel C.3: 25\% Vs 7.1\%).

Panel D indicates that the biggest percentages of foreign affiliates with both intrafirm imports and exports are in Mining (41.2\%), Low-tech manufacturing (30.1\%), and Agriculture (24.5\%), while the smallest percentages in Services (1\%) and EGW supply and Construction (3.6\%). The pattern in Panel D.1 (i.e., for firms whose parents are located in high-income countries) is very similar to the one in Panel D. The percentages though, of affiliates with both intra-firm imports and exports are much higher in Mining (62.5\%), and Resource-based and Low-tech manufacturing $(24.4 \%$ and $36.1 \%$, respectively). However, the percentage of affiliates in Services is zero. Panel D.2 (i.e., foreign affiliates with both intra-firm imports and exports whose parents are located in 


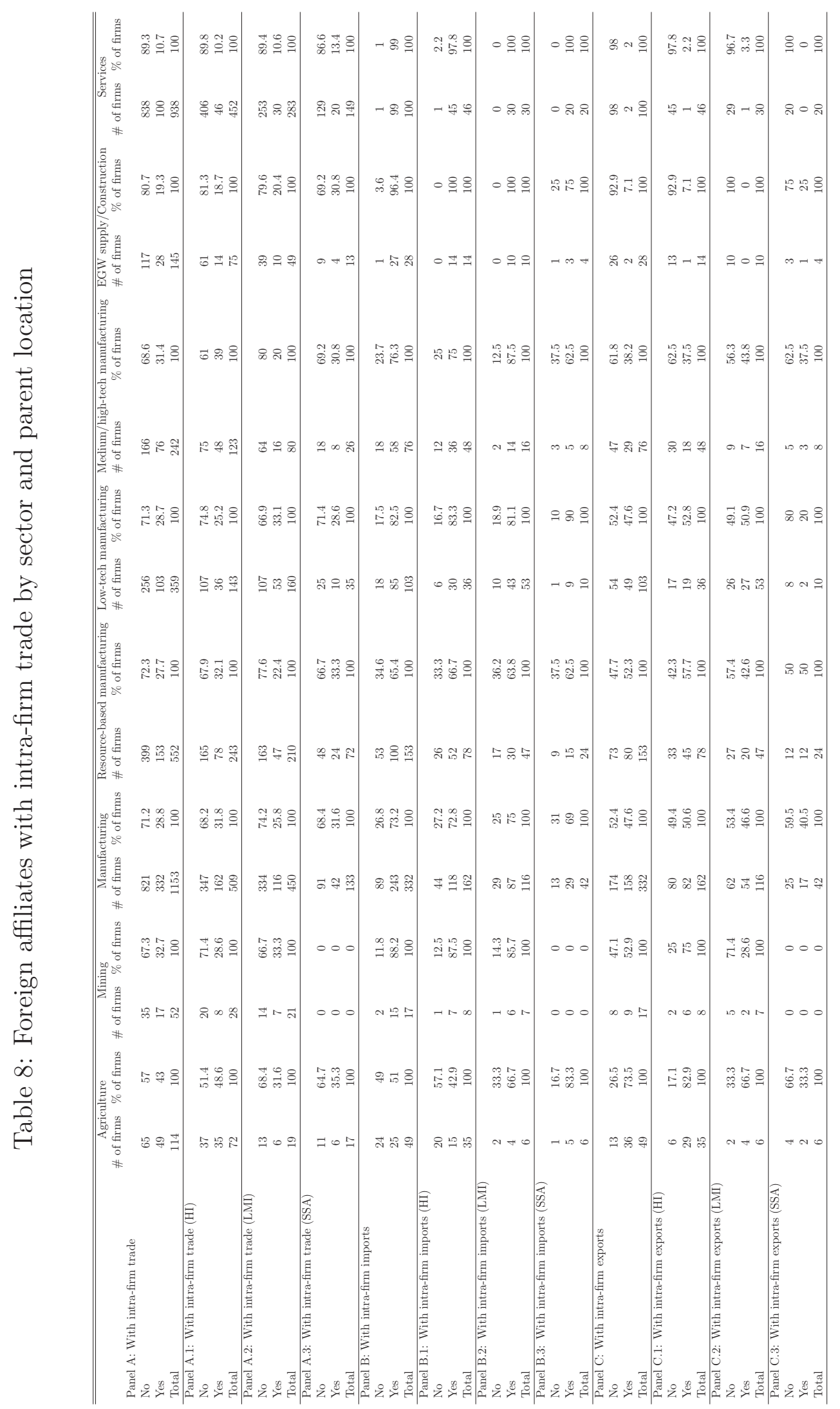


Sotiris Blanas and Adnan Seric

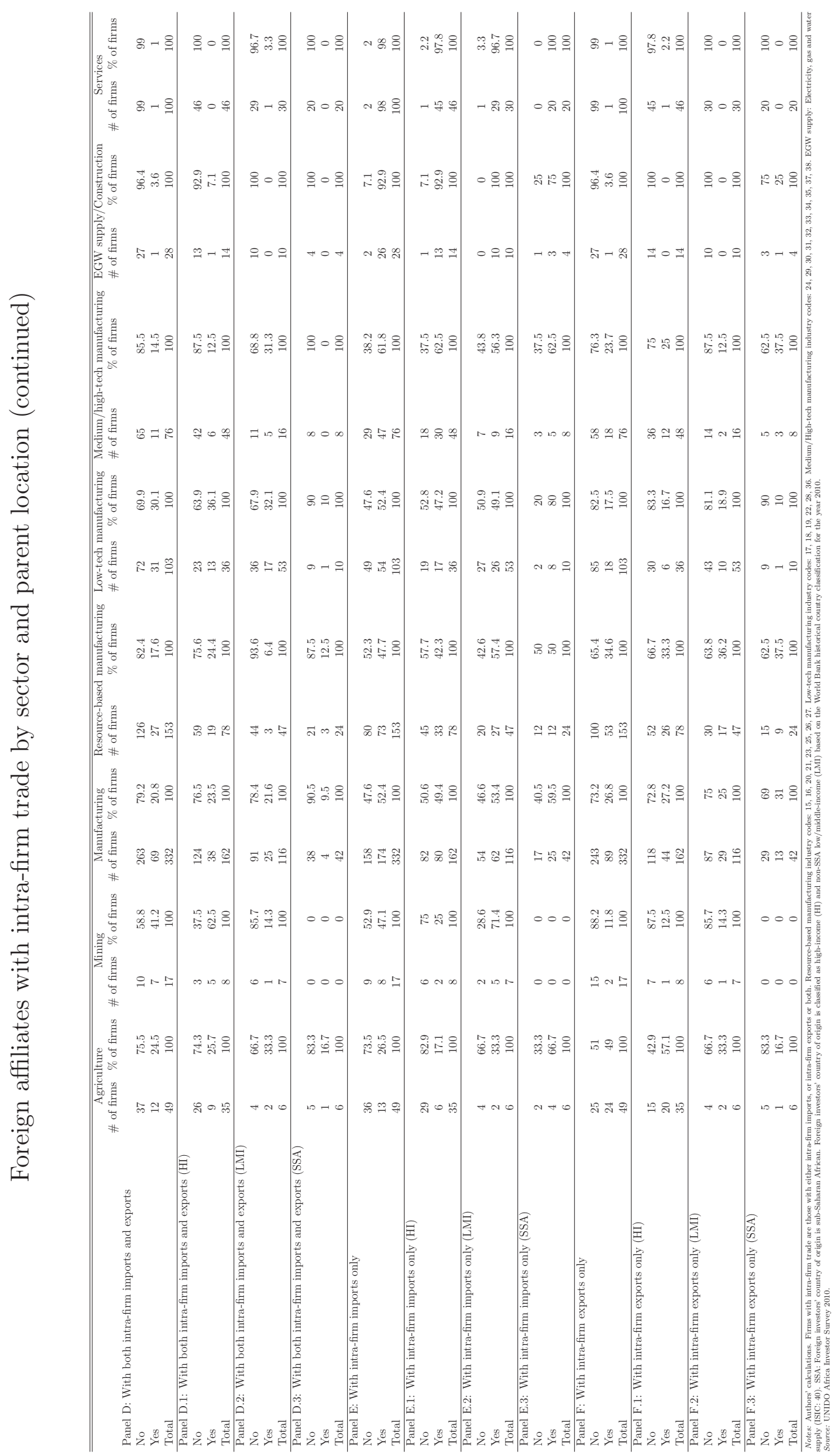


non-SSA low/middle-income countries) displays a different pattern. The highest percentages of these type of affiliates belong to Agriculture (33.3\%), and Low-tech and Medium/High-tech manufacturing (32.1\% and 31.3\%, respectively), while the lowest ones to Services (3.3\%) and Resource-based manufacturing (6.4\%). EGW supply and Construction includes no firms of this type. Panel D.3 (i.e., foreign affiliates with both intra-firm imports and exports whose parents are based in SSA countries) shows that there are no firms of this type in Mining, Medium/High-tech manufacturing, EGW supply and Construction, and Services. Also, their percentages in Agriculture, and Resource-based and Low-tech manufacturing are much smaller than those in Panel D.

Panel E displays for each sector the percentages of foreign affiliates which have only intra-firm imports. The highest ones are found in Services (98\%) and EGW supply and Construction (92.9\%), in Manufacturing (52.4\%), and in particular, in Low-tech and Medium/High-tech manufacturing (52.4\% and 61.8\%, respectively). The lowest ones are found in Agriculture (26.5\%) and Mining (47.1\%). Most of these percentages decline in all industries but Services and EGW supply and Construction when the parents of these affiliates are based in high-income countries. The percentages of firms whose parents are in non-SSA low/middle-income countries (Panel E.2) and in SSA countries (Panel E.3) remain as high as in Panel E in Services and EGW supply and Construction. The percentages of the first firm type are higher in Agriculture (33.3\%) and in Mining $(71.4 \%)$. There are not any differences in Manufacturing. The percentages of the second firm type are much higher in Agriculture (66.7\%) and in Low-tech manufacturing (80\%).

As Panels F to F.3 are mirror images of Panels E to Panel E.3, they indicate that the lowest percentages of foreign affiliates which have only intra-firm exports are to be found in Services (1\%) and EGW supply and Construction (3.6\%), regardless of the origin of the parent company. In most of the industries, the percentage of foreign affiliates whose parents come from high-income countries is higher than that in Panel F. The opposite is true for foreign affiliates whose parents come from non-SSA low/middleincome countries and SSA countries (Panels F.2 and F.3). The exceptions are firms in Mining (14.3\%), Resource-based manufacturing (36.2\%), and Low-tech manufacturing (18.9\%) in Panel F.2, and firms in Manufacturing (31\%), and especially, in Resourcebased manufacturing and Medium/High-tech manufacturing (37.5\% each) in Panel F.3.

Given that foreign affiliates trade mostly at arms' length, we produce the same tables for those with trade (i.e., either intra-firm or arms' length trade, or both) (Table A1), for those which trade only at arms' length (Table A2), as well as for those which trade only within firm boundaries (Table A3). The tables are provided in the Appendix and reveal, similar to Table 8 , that there is salient heterogeneity by sector and by sector and parent location. In contrast to foreign affiliates with intra-firm trade, those which trade at arms' length are the majority for almost all combinations of sectors and parent locations.

Having found evidence for the scarcity of intra-firm trade as Ramondo et al. (2011), and the popularity of arm's length trade even among foreign affiliates with intra-firm trade, we compare the distributions of the two firms types in terms of their size and productivity level. The top panel of Figure ?? plots the kernel densities of the two firm types in terms of their size, proxied by the log of the total number of employees, while the bottom panel the densities in terms of their level of productivity, proxied by the log of the ratio of total sales to total number of employees. Both panels show 
that the distribution of foreign affiliates with intra-firm trade is more skewed to the left compared to the distribution of those without intra-firm trade. In other words, the density of foreign affiliates with intra-firm trade is greater for higher values of size and productivity.

Figure 1: Density of foreign affiliates by size and productivity

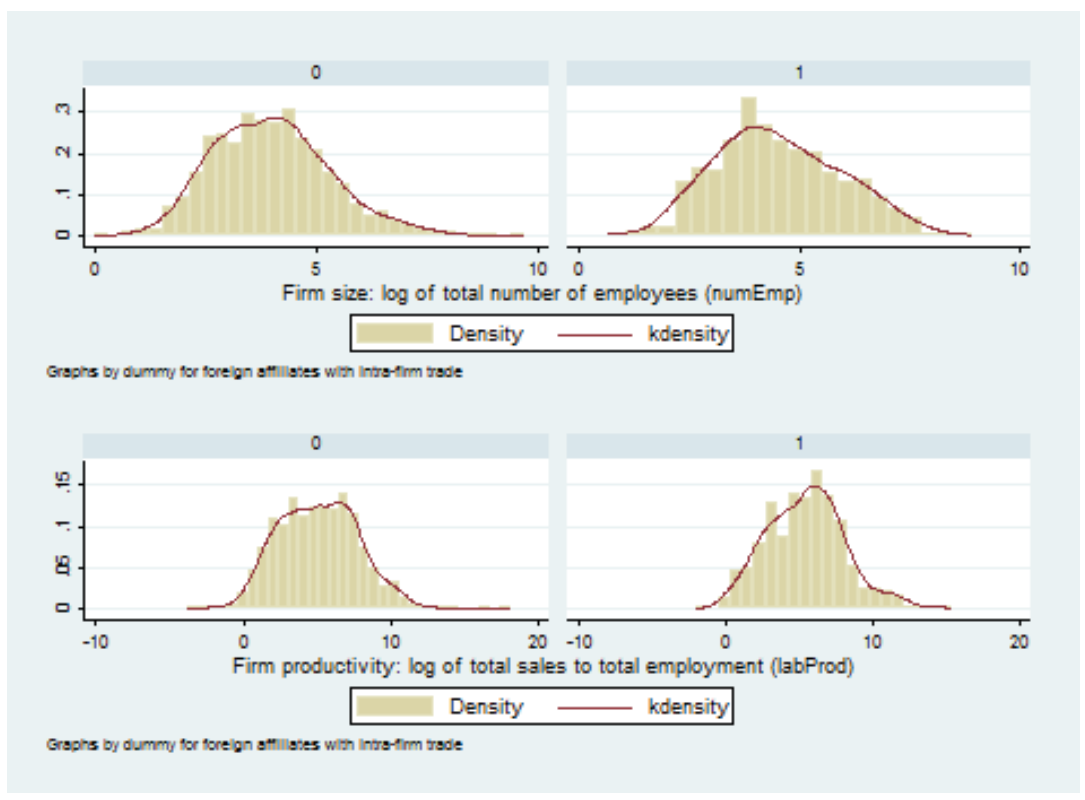

Figure 2: Foreign affiliates by size and productivity in percentiles

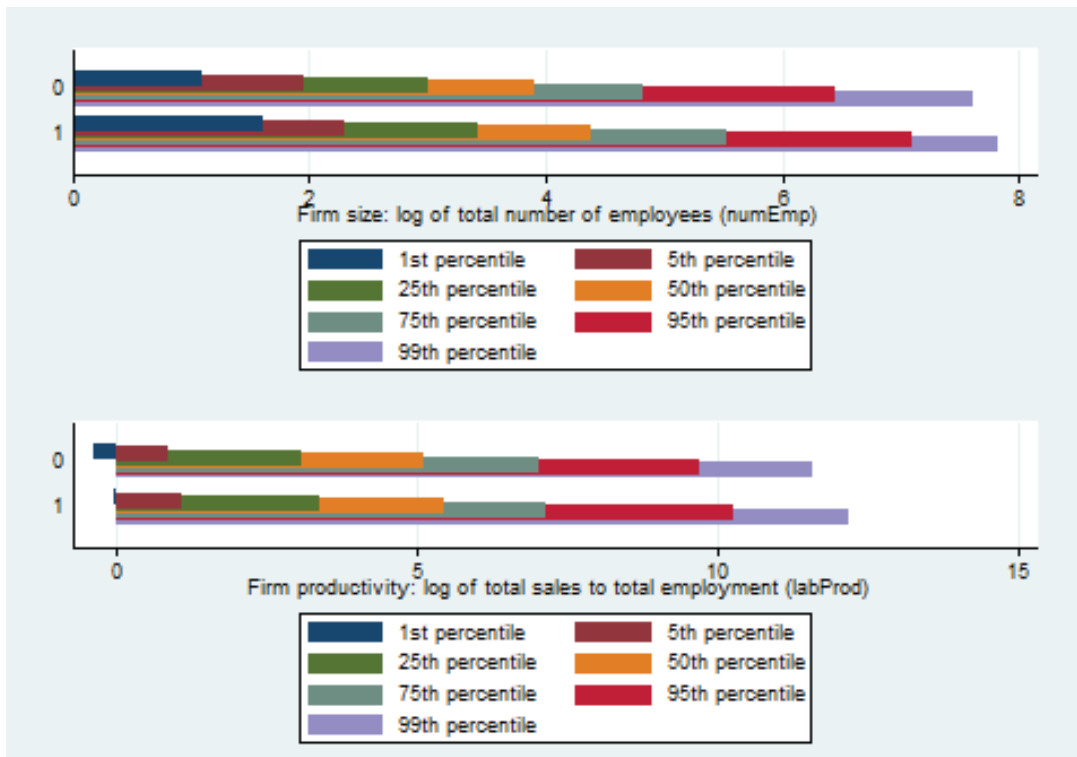

We draw the same conclusions from Figure 2 which plots the percentile distributions 
of the two firm types in terms of size (top panel) and productivity (bottom panel). Foreign affiliates with intra-firm trade have higher size and productivity values at all seven percentiles examined.

We obtain very similar kernel densities and percentile distributions in graphs that we plot with alternative proxies for size and productivity. We proxy size with total sales (Figures A1 and A2 in Appendix A) and productivity with the ratio of value added to total number of employees (Figures A3 and A4 in Appendix A) and total factor productivity (Figures A5 and A6 in Appendix A).

\section{$3 \quad$ Econometric model}

We estimate a probit model in order to investigate which firm characteristics are more likely to be pertinent to one of the two firm types. For firm z in (host) country c and industry $\mathrm{j}$, whose parent company is located in country $\mathrm{p}$, the estimating benchmark model is the following:

$$
\begin{aligned}
D_{i f t, z c j p}= & \alpha+\beta_{1} * \text { skillInt }_{z c j p}+\beta_{2} * \text { capInt }_{z c j p}+\beta_{3} * n u m E m p_{z c j p} \\
& +\beta_{4} * \text { wageEmp }_{z c j p}+\beta_{5} * \operatorname{labProd}_{z c j p}+\beta_{6} * \text { inpInt }_{z c j p} \\
& +\beta_{7} * D_{\text {training }_{z c j p}}+\beta_{c} * D_{c}+\beta_{j} * D_{j}+\beta_{p} * D_{p}+\epsilon_{z c j p}
\end{aligned}
$$

where the dependent variable, $D_{i f t, z c j p}$, is a dummy taking value 1 if firm z has any type of intra-firm trade flows (i.e., either intra-firm imports, or intra-firm exports, or both), and 0 otherwise; skillInt is the log of skill intensity (i.e., share of technical, supervisory and managerial employees in total number of employees), capInt is the log of capital intensity (i.e., ratio of capital stock to total number of employees), numEmp is the log of total number of employees as a proxy for firm size, wageEmp is the log of wage per employee (i.e., total wage bill over total number of employees), labProd is the log of labour productivity (i.e., ratio of total sales to total number of employees), inpInt is the $\log$ of input intensity (i.e., ratio of value of inputs to total number of employees), $D_{\text {training }}$ is a dummy which takes value 1 if firm $\mathrm{j}$ provides formal internal/external training to its employees and 0 otherwise, $D_{c}$ is a set of host-country dummies, $D_{j}$ a set of industry dummies, and $D_{p}$ a set of parent-location dummies (i.e., country of origin of the parent company).

The host-country dummies control for any unobserved heterogeneity across the countries which receive foreign investment (e.g. cross-country differences in institutional quality and business environment). By adding industry dummies, we control for any unobserved heterogeneity across industries (e.g. technology and knowledge intensity of industries). The parent-location dummies account for any unobserved heterogeneity across the countries of origin of the investors (e.g. cross-country differences in corporate culture).

The interpretation of the coefficient estimates is as follows. A positive and statistically significant coefficient estimate indicates that foreign affiliates with intra-firm trade are more likely to acquire the respective characteristic as compared to those without intra-firm trade. Likewise, a negative coefficient estimate implies that the probability foreign affiliates with intra-firm trade have the respective characteristic is lower. 


\section{Empirical results}

\subsection{Main results}

The results from the probit estimation of equation 1 are portrayed in column 1 of Table 9. The coefficient estimates of firm size and labour productivity are positive and significant at the level of $1 \%$. The estimated coefficients of skill and capital intensity are negative but not statistically significant. Those of the average wage, input intensity, and the dummy for provision of training to employees are all positive and insignificant.

In column 2, we use total sales as an alternative proxy for firm size and drop labour productivity in order to avoid collinearity. Its coefficient estimate is still positive and highly significant. In columns 3 , we run the same probit regression as in column 1 , with the only difference that we substitute total factor productivity for labour productivity. By and large, the results are the same with those in column 1. The magnitude of the coefficient estimate of the main proxy for firm size is smaller and significant only at $5 \%$.

Table 9: Main characteristics

\begin{tabular}{|c|c|c|c|c|c|c|}
\hline & (1) & (2) & (3) & (4) & (5) & (6) \\
\hline & $D_{i f t}$ & $D_{i f t}$ & $D_{i f t}$ & $D_{i f e x}$ & $D_{\text {ifim }}$ & $D_{\text {ifimex }}$ \\
\hline \multirow{2}{*}{ skillint } & -0.0153 & -0.0198 & -0.0169 & -0.00840 & -0.00241 & -0.00102 \\
\hline & {$[0.014]$} & {$[0.013]$} & {$[0.014]$} & {$[0.0086]$} & {$[0.012]$} & {$[0.0050]$} \\
\hline \multirow[t]{2}{*}{ capInt } & -0.00580 & -0.00667 & -0.00113 & -0.00179 & -0.00351 & -0.000100 \\
\hline & {$[0.0077]$} & {$[0.0076]$} & {$[0.0075]$} & {$[0.0050]$} & {$[0.0065]$} & {$[0.0029]$} \\
\hline \multirow{2}{*}{ numEmp } & $0.0476^{* * *}$ & & $0.0283^{* *}$ & $0.0352^{* * *}$ & $0.0232 * * *$ & $0.0146^{* * *}$ \\
\hline & {$[0.010]$} & & {$[0.012]$} & {$[0.0069]$} & {$[0.0087]$} & {$[0.0041]$} \\
\hline \multirow[t]{2}{*}{ wageEmp } & 0.0170 & 0.0148 & 0.0147 & 0.000245 & $0.0178^{*}$ & 0.00267 \\
\hline & {$[0.012]$} & {$[0.011]$} & {$[0.012]$} & {$[0.0075]$} & {$[0.0100]$} & {$[0.0044]$} \\
\hline \multirow[t]{2}{*}{ labProd } & $0.0332^{* * *}$ & & & $0.0231^{* * *}$ & $0.0216^{* *}$ & $0.0109^{* *}$ \\
\hline & {$[0.0099]$} & & & {$[0.0071]$} & {$[0.0087]$} & {$[0.0048]$} \\
\hline \multirow[t]{2}{*}{ inpInt } & 0.00442 & 0.00132 & 0.00278 & -0.00233 & 0.00739 & 0.00205 \\
\hline & {$[0.0080]$} & {$[0.0075]$} & {$[0.0079]$} & {$[0.0052]$} & {$[0.0072]$} & {$[0.0033]$} \\
\hline \multirow{2}{*}{$D_{\text {training }}(\mathrm{d})$} & 0.0219 & 0.0241 & 0.0187 & -0.0126 & $0.0355^{*}$ & -0.00395 \\
\hline & {$[0.023]$} & {$[0.023]$} & {$[0.023]$} & {$[0.014]$} & [0.019] & {$[0.0088]$} \\
\hline \multicolumn{2}{|l|}{ totSales } & $\begin{array}{c}0.0403^{* * *} \\
{[0.0072]}\end{array}$ & & & & \\
\hline \multicolumn{2}{|l|}{$t f p$} & & $\begin{array}{c}0.0394^{* * *} \\
{[0.010]}\end{array}$ & & & \\
\hline Obs & 1581 & 1581 & 1580 & 1247 & 1555 & 940 \\
\hline Pseudo- $R^{2}$ & 0.20 & 0.20 & 0.21 & 0.28 & 0.17 & 0.30 \\
\hline Log-likelihood & -730.0 & -730.5 & -728.1 & -382.1 & -644.2 & -194.0 \\
\hline 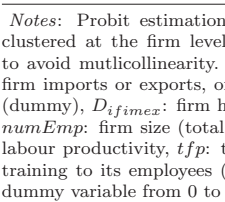 & & & & mmies & lumns. s & $\begin{array}{l}\text { rd errors are } \\
\text { productivity } \\
\text { m has intra }\end{array}$ \\
\hline
\end{tabular}

In column 4, we re-estimate the benchmark model by having as dependent variable a dummy which takes value 1 if the foreign affiliate has intra-firm exports $\left(D_{\text {ifex }}\right)$. Affiliates with intra-firm exports seem to be bigger and more productive than those without intra-firm exports. The first finding is in line with that of Ramondo et al. (2011) who use the same dependent variable.

The same authors use also imports of foreign affiliates from their parent as dependent variable. In the same direction, Hanson et al. (2001) study the flows of intermediate 
goods from the parent to the foreign affiliate by using a measure of the affiliate size. In addition, as already discussed in Section 2, we find that, among foreign affiliates with intra-firm trade, the number of these with intra-firm imports is exceptionally high in many sectors of the economy (Mining, Low-tech and Medium/High-tech manufacturing, EGW supply and Construction, Services). Hence, we estimate the benchmark model with a dummy as dependent variable, which is equal to 1 if the foreign affiliate has intra-firm imports. The results remain unchanged and are shown in column 5.

Using the narrow definition of "vertical" FDI, according to which the foreign affiliate has both intra-firm imports and exports, we re-estimate the benchmark model after replacing the dependent variable with a dummy which takes value 1 if the affiliate has both intra-firm flows. The main results still hold and are shown in column 6 .

In short, we conclude that the average foreign affiliate with intra-firm trade tends to have bigger size and higher level of productivity. In the next section, we perform several test to check the robustness of these results.

\subsection{Robustness checks}

In this section, we perform several tests in order to check the robustness of the main results of Table 9. All relevant tables are relegated to the Appendix. By and large, the regressions estimated pass successfully the robustness checks.

We re-estimate all 7 regressions after restricting the sample to the manufacturing sector (Table B1), to majority-owned foreign affiliates (MOFAs) (i.e., those owned by their parent by at least 50\%) in the whole economy (Table B2) and to MOFAs in manufacturing (Table B3).

In the benchmark case we construct the dummy for intra-firm trade by assuming that any missing observations of intra-firm imports and exports are due to the fact that the firm did not have any intra-firm flows and the respondent of the questionnaire left the relevant questions unanswered. However, it may also be the case that the respondent did not want to disclose such kind of information. We control for this possibility by dropping all missing observations of intra-firm flows. Then, we estimate all 7 regressions for the whole economy (Table B4), the manufacturing sector (Table B5), for MOFAs in the whole economy (Table B6) and the manufacturing sector (Table B7).

In order to ensure that the positive and significant coefficient estimates of size and productivity do not simply capture the age of the firm (i.e., the older the firm, the bigger its size and the higher its productivity), we augment all 7 regressions with firm age (Table B8).

We also test the sensitivity of results to alternative functional forms, such as the logistic (Table B9) and linear probability models (Table B10).

We replace dummies for the country of the foreign investor with dummies for a broader definition of parent location. That is, we construct dummies for whether the parent is domiciled in a high-income, or non-SSA low/middle-income, or SSA country (Table B11). We also replace the host-country and industry dummies with dummies for pairs of host countries and industries (Table B12).

In robustness checks related to firm productivity and performance, we examine any differences regarding the most important reason for production capacity underutilisation under normal circumstances. We find that the probability of foreign affiliates 
with intra-firm trade not having their production capacity under-utilised under normal circumstances is higher (Table B13). Motivated by the literature on credit constraints and export performance (e.g. Chor and Manova, 2012) and the vulnerability of SSA to financial crises mostly through the disruption of the finance of trade channels (Berman and Martin, 2010), we also identify any differences in the change in their performance after the financial crisis of 2007-2008. We use two different measures. The first is based on the firm's performance compared to overall expectations before the crisis (Table B14) and compared to revised expectations after the crisis (Table B15). The second is the average level of capacity utilisation of the firm three years before the crisis and immediately after (Tables B16 to B20). There do not seem to be any statistically significant differences in terms of firm performance either before or after the global financial crisis.

\subsection{Selection into intra-firm trade}

Helpman et al. (2004) and Bernard et al. (2007) find that US exporters have a productivity advantage over US non-exporters in 1996 and 1997, respectively. The second study also reports productivity and employment premia for importers over non-importers, as well as for importers-exporters over those without imports and exports. Employment, sales and productivity premia of importers over non-importers are also found by Antràs et al. (2014). Given that importing activities may result in an increase in firm productivity (Amiti and Konings, 2007), they also show that these premia existed before these firms began importing. Since we don't have data for any year prior to the one examined (i.e., 2010), we are not able to test this either for imports or exports.

The graphical analysis in Section 2.2 shows that foreign affiliates with intra-firm seem to have an advantage in terms of size and productivity. In Table 10, we show the results from OLS regressions which quantify size and productivity premia. In Panel A, we regress the log of each proxy for firm productivity and size on a dummy for intrafirm trade (i.e., it takes value 1 if the foreign affiliates has either intra-firm imports, or exports, or both) and additional controls such as: skill intensity, capital intensity, input intensity, total employment, host-country, parent-location and industry dummies. ${ }^{8}$ The proxies for firm productivity are the following: ratio of total sales to total employment (column 1), ratio of value added to total employment (column 3), and total factor productivity (column 5). The proxies for firm size are: total employment (column 2) and total sales (column 4). We find that the productivity premia are between $25.4 \%$ (column 1) and $30.7 \%$ (column 5), while the size premia are between $31.5 \%$ (column 2) and $56.3 \%$ (column 4).

In Panel B, we run the same regressions as in Panel A after controlling for firms with only arms' length trade. We do this by adding a dummy with value 1 if the firm has either imports or exports or both, but only at arms' length $\left(D_{\text {armt }}\right)$. Not surprisingly, we observe the same sorting pattern and even greater size and productivity premia.

\footnotetext{
${ }^{8}$ Firm size regressions omit the log of total employment as a covariate.
} 
Table 10: Productivity and size premia of foreign affiliates with intra-firm and arm's length trade

\begin{tabular}{|c|c|c|c|c|c|}
\hline \multicolumn{6}{|c|}{ Foreign affiliates with intra-firm trade } \\
\hline & (1) & (2) & (3) & (4) & $(5)$ \\
\hline \multirow{3}{*}{$D_{i f t}$} & Productivity & Size & Productivity & Size & Productivity \\
\hline & $0.254^{* * *}$ & $0.315^{* * *}$ & $0.255^{* *}$ & $0.563^{* * *}$ & $0.307^{* * *}$ \\
\hline & {$[0.066]$} & {$[0.066]$} & {$[0.10]$} & {$[0.090]$} & {$[0.067]$} \\
\hline Obs & 1815 & 1831 & 1348 & 1815 & 1812 \\
\hline \multicolumn{6}{|c|}{ Panel B: Foreign affiliates with intra-firm and arm's length trade } \\
\hline \multirow{4}{*}{$D_{i f t}$} & (1) & $(2)$ & $(3)$ & $(4)$ & (5) \\
\hline & Productivity & Size & Productivity & Size & Productivity \\
\hline & $0.292^{* * *}$ & $0.606^{* * *}$ & $0.334^{* *}$ & $0.888^{* * *}$ & $0.376^{* * *}$ \\
\hline & {$[0.094]$} & {$[0.093]$} & {$[0.14]$} & {$[0.13]$} & {$[0.096]$} \\
\hline \multirow[t]{2}{*}{$D_{\text {armt }}$} & 0.0450 & $0.348^{* * *}$ & 0.0958 & $0.390 * * *$ & 0.0820 \\
\hline & {$[0.083]$} & {$[0.079]$} & {$[0.11]$} & {$[0.12]$} & {$[0.084]$} \\
\hline Obs & 1815 & 1831 & 1348 & 1815 & 1812 \\
\hline \multicolumn{6}{|c|}{ Panel C: Foreign affiliates with different intra-firm flows } \\
\hline \multirow{4}{*}{$D_{\text {ifimonly }}$} & $(1)$ & $(2)$ & $(3)$ & $(4)$ & $(5)$ \\
\hline & Productivity & Size & Productivity & Size & Productivity \\
\hline & $0.255^{* *}$ & $0.489 * * *$ & 0.164 & $0.732^{* * *}$ & $0.342^{* * *}$ \\
\hline & {$[0.10]$} & {$[0.11]$} & {$[0.16]$} & {$[0.15]$} & {$[0.11]$} \\
\hline \multirow{2}{*}{$D_{\text {ifexonly }}$} & $0.282^{* *}$ & $0.719^{* * *}$ & $0.504^{* * *}$ & $0.992^{* * *}$ & $0.358^{* * *}$ \\
\hline & {$[0.12]$} & {$[0.13]$} & {$[0.17]$} & {$[0.17]$} & {$[0.13]$} \\
\hline \multirow[t]{2}{*}{$D_{\text {ifimex }}$} & $0.453^{* * *}$ & $0.869 * * *$ & $0.559^{* *}$ & $1.308 * * *$ & $0.536^{* * *}$ \\
\hline & {$[0.17]$} & {$[0.15]$} & {$[0.24]$} & {$[0.23]$} & {$[0.17]$} \\
\hline \multirow[t]{2}{*}{$D_{\text {armt }}$} & 0.0479 & $0.353^{* * *}$ & 0.103 & $0.397^{* * *}$ & 0.0848 \\
\hline & {$[0.083]$} & {$[0.079]$} & {$[0.11]$} & {$[0.12]$} & {$[0.084]$} \\
\hline Obs & 1815 & 1831 & 1348 & 1815 & 1812 \\
\hline \multicolumn{6}{|c|}{$\begin{array}{l}\text { Notes: OLS estimations with control variables in both panels and all columns: skill intensity, capital intensity, } \\
\text { input intensity, total employment, host-country, parent-location and industry dummies. Firm size regressions } \\
\text { omit the log of total employment as a covariate. Standard errors are clustered at the firm level. Productivity } \\
\text { (column } 1 \text { ): log of the ratio of total sales to total employment. Size (column 2): total employment. Productivity } \\
\text { (column 3): log of the ratio of value added to total employment. Size (column 4): log of total sales. Productivity } \\
\text { (column 5): } \log \text { of total factor productivity. Panels A and B: } D_{i f t} \text { : firm has intra-firm imports or exports, or } \\
\text { both (dummy). Panels B and C: } D_{a r m t} \text { : firm with arms' length trade only (i.e., either arms' length imports or } \\
\text { exports or both but with no intra-firm trade). Panel C: } D_{\text {ifimonly }} \text { : firm has intra-firm imports only (dummy), } \\
D_{\text {ifexonly: }} \text { : firm has intra-firm exports only (dummy), } D_{\text {ifimex }} \text { : firm has both intra-firm imports and exports } \\
\text { (dummy). Dummies take value } 1 \text { if the statement holds, and } 0 \text { otherwise. All variables are in logs except for } \\
\text { dummies. }\end{array}$} \\
\hline
\end{tabular}

In Panel $\mathrm{C}$, we regress the same dependent variables on dummies for intra-firm imports only (i.e., it takes value 1 if the firm has only intra-firm imports), intra-firm exports only (i.e., it takes value 1 if the firm has only intra-firm exports), for both intrafirm imports and exports (i.e., it takes value 1 if the firm has both intra-firm imports and exports), for arm's length trade only, and the same control variables as in Panels A and B. Column 1 shows that foreign affiliates with only intra-firm imports, with only intra-firm exports and with both intra-firm imports and exports have a productivity advantage of $25.5 \%, 28.2 \%$, and $45.3 \%$, respectively, over those without intra-firm trade. The same sorting pattern arises when we use the other two proxies for firm productivity in columns 3 and 5 . In all three columns, we fail to find any statistically significant premia for foreign affiliates which trade only at arm's length. In terms of size premia, these are: $48.9 \%$ for foreign affiliates with intra-firm imports only, $71.9 \%$ for foreign affiliates with intra-firm exports only, and $86.9 \%$ for foreign affiliates with both intrafirm imports and exports (column 2). Those with arm's length trade have the smallest size premia, of $35.3 \%$. We obtain the same sorting pattern with even larger premia with the alternative proxy for firm size in column 4 . We also find the same sorting pattern when we drop from the regressions the dummy for only arm's length trade but, as expected, the productivity and size premia are smaller. 
Table 11: Productivity and size premia of foreign affiliates with intra-firm and arm's length trade (Manufacturing sector)

\begin{tabular}{|c|c|c|c|c|c|}
\hline \multicolumn{6}{|c|}{ Panel A: Foreign affiliates with intra-firm trade } \\
\hline \multirow{4}{*}{$D_{i f t}$} & (1) & $(2)$ & $(3)$ & (4) & $(5)$ \\
\hline & Productivity & Size & Productivity & Size & Productivity \\
\hline & $0.216^{* * *}$ & $0.303^{* * *}$ & $0.243^{* *}$ & $0.524^{* * *}$ & $0.296^{* * *}$ \\
\hline & {$[0.076]$} & {$[0.079]$} & {$[0.12]$} & {$[0.11]$} & {$[0.081]$} \\
\hline \multirow{3}{*}{ Panel } & 961 & 963 & 835 & 961 & 957 \\
\hline & oreign affiliat & with int & -firm and arr & length & \\
\hline & (1) & $(2)$ & $(3)$ & (4) & $(5)$ \\
\hline \multirow{3}{*}{$D_{i f t}$} & Productivity & Size & Productivity & Size & Productivity \\
\hline & $0.313^{* * *}$ & $0.667^{* * *}$ & $0.470 * * *$ & $0.996^{* * *}$ & $0.393^{* * *}$ \\
\hline & {$[0.12]$} & {$[0.12]$} & {$[0.18]$} & {$[0.18]$} & {$[0.13]$} \\
\hline \multirow[t]{2}{*}{$D_{\text {armt }}$} & 0.112 & $0.428 * * *$ & 0.266 & $0.555^{* * *}$ & 0.113 \\
\hline & {$[0.11]$} & {$[0.11]$} & {$[0.16]$} & {$[0.17]$} & {$[0.12]$} \\
\hline Obs & 961 & 963 & 835 & 961 & 957 \\
\hline \multicolumn{6}{|c|}{ Panel C: Foreign affiliates with different intra-firm flows } \\
\hline \multirow{4}{*}{$D_{\text {ifimonly }}$} & (1) & $(2)$ & $(3)$ & $(4)$ & $(5)$ \\
\hline & Productivity & Size & Productivity & Size & Productivity \\
\hline & 0.198 & $0.490^{* * *}$ & 0.263 & $0.698^{* * *}$ & $0.323^{* *}$ \\
\hline & {$[0.13]$} & {$[0.13]$} & {$[0.20]$} & {$[0.20]$} & {$[0.14]$} \\
\hline \multirow{2}{*}{$D_{\text {ifexonly }}$} & $0.386^{* * *}$ & $0.820^{* * *}$ & $0.615^{* * *}$ & $1.218^{* * *}$ & $0.407^{* * *}$ \\
\hline & {$[0.13]$} & {$[0.15]$} & {$[0.21]$} & {$[0.19]$} & {$[0.14]$} \\
\hline \multirow[t]{2}{*}{$D_{\text {ifimex }}$} & $0.533^{* *}$ & $0.898 * * *$ & $0.793^{* * *}$ & $1.445^{* * *}$ & $0.578^{* *}$ \\
\hline & {$[0.23]$} & {$[0.17]$} & {$[0.30]$} & {$[0.30]$} & {$[0.23]$} \\
\hline \multirow[t]{2}{*}{$D_{\text {armt }}$} & 0.119 & $0.433^{* * *}$ & $0.273^{*}$ & $0.563^{* * *}$ & 0.118 \\
\hline & {$[0.11]$} & {$[0.11]$} & {$[0.16]$} & {$[0.17]$} & {$[0.12]$} \\
\hline Obs & 961 & 963 & 835 & 961 & 957 \\
\hline \multicolumn{6}{|c|}{$\begin{array}{l}\text { Notes: OLS estimations with control variables in both panels and all columns: skill intensity, capital intensity, } \\
\text { input intensity, total employment, host-country, parent-location and industry dummies. Firm size regressions } \\
\text { omit the log of total employment as a covariate. Standard errors are clustered at the firm level. Productivity } \\
\text { (column 1): log of the ratio of total sales to total employment. Size (column 2): total employment. Productivity } \\
\text { (column 3): log of the ratio of value added to total employment. Size (column 4): log of total sales. Productivity } \\
\text { (column 5): log of total factor productivity. Panel A: } D_{i f t} \text { : firm has intra-firm imports or exports, or both } \\
\text { (dummy). Panel B: } D_{\text {ifim }} \text { : firm has intra-firm imports only (dummy), } D_{i \text { fexonly }} \text { : firm has intra-firm exports } \\
\text { only (dummy), } D_{\text {ifimex }} \text { : firm has both intra-firm imports and exports (dummy). Panels A and B: } D_{a r m t} \text { : } \\
\text { firm with arms' length trade only (i.e., either arms' length imports or exports or both but with no intra-firm } \\
\text { trade) (dummy). Dummies take value } 1 \text { if the statement holds, and } 0 \text { otherwise. All variables are in logs } \\
\text { except for dummies. }\end{array}$} \\
\hline
\end{tabular}

We check the robustness of these results by restricting the sample to firms in manufacturing. All columns in Panels A and B of Table 11 confirm the size and productivity advantage of foreign affiliates with intra-firm. Same as in Panels A and B of Table 10, the estimated premia are greater when foreign affiliates with only arm's length trade are controlled for. In addition, these premia are slightly smaller for foreign affiliates with intra-firm trade in manufacturing than in the whole economy when we do not control for foreign affiliates with only arm's length trade. When we control for this type of firms, their premia in manufacturing become greater than those in the whole economy. Importantly, the sorting pattern still holds (Panel C).

The premia documented above may be driven by a potential similarity in terms of size and productivity between foreign affiliates with only arm's length trade and locallyowned firms which engage in international trade. We compute size and productivity premia of these two firm types and find that foreign affiliates with only arm's length trade are dissimilar from domestic firms which trade. As shown in Table 12, they are bigger and more productive by $11.9 \%$ and $25.7 \%$, respectively. We obtain very similar results after restricting the sample to firms in manufacturing (Table B21). 
Table 12: Productivity and size premia of foreign affiliates with arms' length trade over domestic firms with arms' length trade

\begin{tabular}{|c|c|c|c|c|c|}
\hline \multicolumn{6}{|c|}{ Panel A: Foreign affiliates with arms' length trade } \\
\hline \multirow{4}{*}{$D_{\text {ftrade }}$} & (1) & $(2)$ & (3) & (4) & (5) \\
\hline & Productivity & Size & Productivity & Size & Productivity \\
\hline & $0.119^{* * *}$ & $0.257^{* * *}$ & $0.252^{* * *}$ & $0.388^{* * *}$ & $0.106^{* *}$ \\
\hline & {$[0.044]$} & {$[0.044]$} & {$[0.066]$} & {$[0.064]$} & {$[0.043]$} \\
\hline \multirow[t]{2}{*}{$D_{\text {fnotrade }}$} & 0.0759 & $-0.188^{* * *}$ & $0.242^{* *}$ & -0.108 & 0.0340 \\
\hline & {$[0.070]$} & {$[0.067]$} & {$[0.094]$} & {$[0.10]$} & {$[0.072]$} \\
\hline \multirow{2}{*}{$D_{\text {nofnotrade }}$} & $-0.250 * * *$ & $-0.558^{* * *}$ & $-0.217^{* * *}$ & $-0.832^{* * *}$ & $-0.236^{* * *}$ \\
\hline & {$[0.047]$} & {$[0.041]$} & {$[0.065]$} & {$[0.063]$} & {$[0.044]$} \\
\hline Obs & 4672 & 4722 & 3528 & 4672 & 4647 \\
\hline \multicolumn{6}{|c|}{ Panel B: Foreign affiliates with different arms' length trade flows } \\
\hline \multirow{4}{*}{$D_{\text {fimponly }}$} & $(1)$ & $(2)$ & $(3)$ & $(4)$ & $(5)$ \\
\hline & Productivity & Size & Productivity & Size & Productivity \\
\hline & $0.0987^{*}$ & 0.0444 & $0.294^{* * *}$ & $0.142^{*}$ & 0.0850 \\
\hline & {$[0.053]$} & {$[0.049]$} & {$[0.077]$} & {$[0.075]$} & {$[0.0$} \\
\hline \multirow{2}{*}{$D_{\text {fexponly }}$} & $0.248^{* *}$ & $0.266^{* *}$ & $0.441^{* * *}$ & $0.536^{* * *}$ & $0.302 * * *$ \\
\hline & {$[0.10]$} & {$[0.11]$} & {$[0.13]$} & {$[0.15]$} & {$[0.095]$} \\
\hline \multirow[t]{2}{*}{$D_{\text {fimpexp }}$} & 0.107 & $0.664 * * *$ & 0.102 & $0.797 * * *$ & 0.0664 \\
\hline & {$[0.074]$} & {$[0.073]$} & {$[0.11]$} & {$[0.10]$} & {$[0.070]$} \\
\hline \multirow[t]{2}{*}{$D_{\text {fnotrade }}$} & 0.0781 & $-0.187 * * *$ & $0.247 * * *$ & -0.104 & 0.0375 \\
\hline & {$[0.070]$} & {$[0.067]$} & {$[0.094]$} & {$[0.10]$} & {$[0.072]$} \\
\hline \multirow[t]{2}{*}{$D_{\text {nofnotrade }}$} & $-0.249 * * *$ & $-0.562^{* * *}$ & $-0.209^{* * *}$ & $-0.835^{* * *}$ & $-0.233^{* * *}$ \\
\hline & {$[0.047]$} & {$[0.041]$} & {$[0.065]$} & {$[0.063]$} & {$[0.044]$} \\
\hline Obs & 4672 & 4722 & 3528 & 4672 & 4647 \\
\hline \multicolumn{6}{|c|}{$\begin{array}{l}\text { Notes: OLS estimations with control variables in both panels and all columns: skill intensity, capital intensity, } \\
\text { input intensity, total employment, host-country, parent-location and industry dummies. Firm size regressions omit } \\
\text { the log of total employment as a covariate. Standard errors are clustered at the firm level. Productivity (column } 1) \text { : }\end{array}$} \\
\hline
\end{tabular}

The evidence for self-selection of foreign affiliates into intra-firm and arm's length trade is similar to the evidence for self-selection of firms into aggregate trade (Bernard et al., 2007). However, in Table 13, we show that foreign affiliates with trade (either intra-firm or arms' length trade, or both) have size but not productivity premia (Panel A) and that the aforementioned sorting pattern is found only for size and not for productivity (Panel B). We get very similar results when we study only manufacturing firms (Table B22). 
Table 13: Productivity and size premia of foreign affiliates with trade, both intra-firm and arms' length trade and arms' length trade only

\begin{tabular}{|c|c|c|c|c|c|}
\hline \multicolumn{6}{|c|}{ Panel A: Foreign affiliates with trade } \\
\hline \multirow{4}{*}{$D_{\text {trade }}$} & (1) & $(2)$ & $(3)$ & $(4)$ & $(5)$ \\
\hline & Productivity & Size & Productivity & Size & Productivity \\
\hline & 0.0957 & $0.403^{* * *}$ & 0.145 & $0.499 * * *$ & $0.142^{*}$ \\
\hline & [0.081] & {$[0.077]$} & {$[0.11]$} & {$[0.11]$} & {$[0.082]$} \\
\hline Obs & 1815 & 1831 & 1348 & 1815 & 1812 \\
\hline \multicolumn{6}{|c|}{ Panel B: Foreign affiliates with different trade flows } \\
\hline \multirow{4}{*}{$D_{\text {imponly }}$} & (1) & $(2)$ & $(3)$ & $(4)$ & $(5)$ \\
\hline & Productivity & Size & Productivity & Size & Productivity \\
\hline & 0.0373 & $0.226^{* * *}$ & 0.101 & $0.257^{* *}$ & 0.0613 \\
\hline & {$[0.086]$} & {$[0.080]$} & {$[0.12]$} & {$[0.12]$} & {$[0.087]$} \\
\hline \multirow{2}{*}{$D_{\text {exponly }}$} & 0.176 & $0.371^{* * *}$ & $0.312^{* *}$ & $0.548 * * *$ & $0.287^{* *}$ \\
\hline & {$[0.12]$} & {$[0.11]$} & {$[0.15]$} & {$[0.16]$} & {$[0.12]$} \\
\hline \multirow[t]{2}{*}{$D_{\text {impexp }}$} & $0.181^{*}$ & $0.766^{* * *}$ & 0.139 & $0.937 * * *$ & $0.242^{* *}$ \\
\hline & {$[0.098]$} & {$[0.091]$} & {$[0.14]$} & {$[0.13]$} & {$[0.099]$} \\
\hline Obs & 1815 & 1831 & 1348 & 1815 & 1812 \\
\hline \multicolumn{6}{|c|}{ 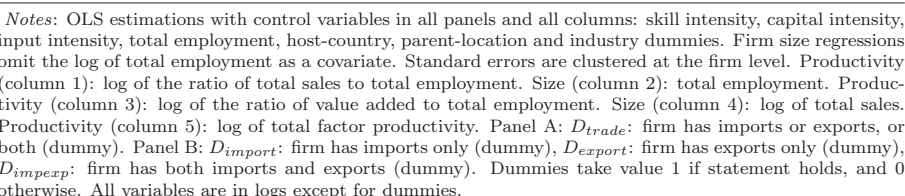 } \\
\hline
\end{tabular}

\subsection{Summary of results and implications for the host country}

We summarise the main findings of the empirical analysis as follows. Foreign affiliates with intra-firm trade account for only a small fraction of all firms in the sample, and are of larger size and higher productivity level. The first two findings are in line with those of Ramondo et al. (2011).

Their size premia range between $31.5 \%$ (size proxied by total number of employees) and $56.3 \%$ (size proxied by total sales). Their productivity premia are $25.4 \%$ (ratio of total sales to total number of employees), $25.5 \%$ (ratio of total value added to total number of employees) and $30.7 \%$ (total factor productivity).

Our evidence for self-selection of foreign affiliates into different intra-firm and arm's length trade flows indicates that, on average, foreign affiliates with both intra-firm imports and exports are the biggest and most productive firms, those with only intrafirm exports smaller and less productive, those with only intra-firm imports even smaller and less productive, while those with only arm's length trade are bigger and more productive only than those without intra-firm trade, which are the smallest and least productive firms. Reporting these premia becomes even more important after we show that foreign affiliates with only arm's length trade differ from domestic firms which engage in international trade in terms of size and productivity. They are bigger and more productive by $11.9 \%$ and $25.7 \%$, respectively.

In attempt to link these findings to host-country effects of FDI, the size premia of the average foreign affiliate with intra-firm trade may in practice result in a higher number of job vacancies to be filled by local job-market seekers. Its productivity premia may imply greater productivity spillovers to local firms (e.g. supplier of inputs) with which it develops linkages. 


\section{Theoretical background}

In this section we describe in detail the theoretical background of our subsequent econometric analysis. Motivated by our findings in section 4 for size and productivity premia of foreign affiliates with intra-firm trade, we start by providing a theoretical explanation for the selection of foreign affiliates into intra-firm trade. In addition, we study theoretically the potential differences between foreign affiliates with and without intra-firm trade in the following areas: stock and flow of intangibles, delegation of authority and grant of rights of control, extensive and intensive margins of sister affiliates, mode of foreign investment of the parent company, extensive and intensive margins of local and international procurement activities and of exporting activities.

In order to explain the selection of foreign affiliates into intra-firm and arm's length trade, we rely on the concept of firm heterogeneity in terms of productivity introduced by Melitz (2003). We plausibly assume that the fixed cost of engaging in intra-firm trade is greater than the fixed cost of engaging in arm's length trade since the first includes the cost of set-up of a new affiliate or the takeover of an existing firm, while the second the cost of search and match with an unaffiliated supplier or buyer (Antras and Helpman, 2004). Although the first fixed cost is initially borne by the parent company which is in charge of building a network of domestic and foreign affiliates, we assume that this cost is shared with its affiliates through intra-firm trade.

In sum, we plausibly assume that the fixed cost of selling in or buying from the hostcountry market is lower than the fixed cost of arm's length trade, which in turn, is lower than the fixed cost of intra-firm trade $\left(f_{D}<f_{\text {arm }}<f_{\text {ift }}\right)$. The productivity cutoffs above which a firm can incur each of these fixed costs have the following order: $\left(\Theta_{D}<\right.$ $\left.\Theta_{\text {armt }}<\Theta_{i f t}\right)$. Hence, only the most productive foreign affiliates, with productivity level of at least $\Theta_{i f t}$ are able to engage in intra-firm trade. Those with intermediate levels of productivity $\left(\Theta_{\text {arm }} \leq \Theta<\Theta_{\text {ift }}\right)$ engage in arm's length trade, while those with lower productivity levels $\left(\Theta_{D} \leq \Theta<\Theta_{\text {armt }}\right)$ only sell in or buy from the host country. Foreign affiliates with productivity below $\Theta_{D}$ exit the market.

After decomposing intra-firm trade into different flows (i.e., imports, exports, both), we assume the following order for their fixed costs: $f_{\text {ifim }}<f_{\text {ifex }}<f_{\text {ifimex }}=f_{\text {ifim }}+$ $f_{\text {ifex }}$. Similarly the order of their corresponding productivity cutoffs are: $\Theta_{\text {ifim }}<$ $\Theta_{\text {ifex }}<\Theta_{\text {ifimex }}$. Eventually, the following sorting pattern arises: the biggest and most productive foreign affiliates engage in both intra-firm imports and exports, smaller and less productive in intra-firm exports, even smaller and even less productive in intrafirm imports, while among those whose size and productivity do not allow them to engage in any type of intra-firm trade, the biggest and most productive have only arm's length trade, smaller and less productive only sell into and source from the host-country market and the least productive exit.

\section{Conclusion}

In this paper we juxtapose the main firm characteristics between foreign affiliates with and without intra-firm trade located in 19 countries in sub-Saharan Africa in 2010.

Foreign affiliates with intra-firm trade are relatively few, of bigger size and higher 
productivity level. We report size and productivity premia of $31.5 \%$ and $25.4 \%$, respectively. The first two findings are in line with those of Ramondo et al. (2011). Further analysis reveals that foreign affiliates self-select into intra-firm and arm's length trade. On average, foreign affiliates with both intra-firm imports and exports seem to be the biggest and most productive firms, those with only intra-firm exports smaller and less productive, those with only intra-firm imports even smaller and less productive, while those with only arm's length trade are bigger and more productive only than those without intra-firm trade, which are the smallest and least productive firms.

After linking these findings to the debate on host-country effects of FDI, we argue that the greater size of the average foreign affiliate with intra-firm trade can be translated into a greater number of job opportunities for local job-market seekers. Moreover, any productivity spillovers to local firms may be higher when these firms develop linkages with the same type of foreign affiliate.

Despite the novelty of all results set out above, some intriguing issues can be studied in more depth while others remain unexplored. First, the time dimension would allow for studying causality and therefore, shed more light on the positive link between intrafirm trade and size and productivity.

Second, given the popularity of arm's length trade among the foreign affiliates in our sample, even among those with intra-firm trade, upon data availability on transactions between buyers and sellers by product, further investigation of the boundaries of the firm would be desirable.

Finally, even if firm boundaries mainly exist for the transfer of intangibles rather than of tangible goods (Atalay et al., 2014), which may be a plausible explanation for our evidence on the scarcity of intra-firm trade, a complementary question arises. Given the strong link between production sharing and knowledge flows (Demsetz, 1988; Simon, 1991; Grant, 1996), are there any differences between foreign affiliates with and without intra-firm trade in terms of knowledge transfers to them from their parent? By definition, the first type of foreign affiliate share production with its parent, while the second, either does not share production or it shares with an affiliated party. In the last case, knowledge associated with production sharing flows through the market and may be subject to inefficiencies that are mitigated within firm boundaries. Thus, the internalisation argument is present again. In addition, if there are indeed any differences between the two firm types in this respect, then one would expect that their concerns over knowledge expropriation from unaffiliated parties (e.g. local suppliers in the host country) could potentially differ as well. Blanas and Seric (2014) look into these two novel and intriguing issues.

\section{References}

Alfaro, L. and Charlton, A. (2009). Intra-industry Foreign Direct Investment. American Economic Review, 99(5):2096-2119.

Amiti, M. and Konings, J. (2007). Trade liberalization, intermediate inputs, and productivity: Evidence from indonesia. The American Economic Review, 97(5):pp. 16111638. 
Antràs, P. (2003). Firms, Contracts, And Trade Structure. The Quarterly Journal of Economics, 118(4):1375-1418.

Antràs, P., Fort, T. C., and Tintelnot, F. (2014). The margins of global sourcing: Theory and evidence from u.s. firms.

Antras, P. and Helpman, E. (2004). Global sourcing. Journal of Political Economy, $112(3): 552-580$.

Atalay, E., Hortacsu, A., and Syverson, C. (2014). Vertical Integration and Input Flows. American Economic Review, 104(4):1120-48.

Badinger, H. and Egger, P. (2010). Horizontal vs. vertical interdependence in multinational activity. Oxford Bulletin of Economics and Statistics, 72(6):744-768.

Berman, N. and Martin, P. (2010). The vulnerability of sub-Saharan Africa to the financial crisis: the case of trade. CEPR Discussion Papers, C.E.P.R. Discussion Papers 7765, C.E.P.R. Discussion Papers.

Bernard, A. B., Jensen, J. B., Redding, S. J., and Schott, P. K. (2007). Firms in International Trade. Journal of Economic Perspectives, American Economic Association, 21(3):105-130.

Bernard, A. B., Jensen, J. B., Redding, S. J., and Schott, P. K. (2012). The Empirics of Firm Heterogeneity and International Trade. Annual Review of Economics, Annual Reviews, 4(1):283-313.

Blanas, S. and Seric, A. (2014). Knowledge transfer, knowledge expropriation and intra-firm trade. Technical report.

Bloom, N. and Van Reenen, J. (2007). Measuring and explaining management practices across firms and countries. The Quarterly Journal of Economics, 122(4):1351-1408.

Borga, M. and Zeile, W. J. (2004). International fragmentation of production and the intrafirm trade of u.s. multinational companies. BEA Papers 0035, Bureau of Economic Analysis.

Brainard, S. L. (1997). An Empirical Assessment of the Proximity-Concentration Tradeoff between Multinational Sales and Trade. American Economic Review, 87(4):520 44 .

Carr, D. L., Markusen, J. R., and Maskus, K. E. (2001). Estimating the knowledgecapital model of the multinational enterprise. The American Economic Review, 91(3):pp. 693-708.

Caves, R. (1982). Multinational Enterprise and Economic Analysis. Cambridge, UK: Cambridge University Press.

Chor, D. and Manova, K. (2012). Off the cliff and back? Credit conditions and international trade during the global financial crisis. Journal of International Economics, Elsevier, 87(1):117-133. 
Corcos, G., Irac, D. M., Mion, G., and Verdier, T. (2013). The Determinants of Intrafirm Trade: Evidence from French Firms. The Review of Economics and Statistics, 95(3):825-838.

Demsetz, H. (1988). The theory of the firm revisited. Journal of Law, Economics, Organization, 4(1):pp. 141-161.

Ekholm, K., Forslid, R., and Markusen, J. R. (2007). Export-Platform Foreign Direct Investment. Journal of the European Economic Association, 5(4):776-795.

Feinberg, S. E. and Keane, M. P. (2001). U.S.-Canada Trade Liberalization And Mnc Production Location. The Review of Economics and Statistics, 83(1):118-132.

Garicano, L. and Rossi-Hansberg, E. (2006). Organization and inequality in a knowledge economy. The Quarterly Journal of Economics, 121(4):1383-1435.

Grant, R. M. (1996). Toward a knowledge-based theory of the firm. Strategic Management Journal, 17(S2):109-122.

Grossman, G. M., Helpman, E., and Szeidl, A. (2006). Optimal integration strategies for the multinational firm. Journal of International Economics, 70(1):216-238.

Grossman, S. J. and Hart, O. D. (1986). The costs and benefits of ownership: A theory of vertical and lateral integration. Journal of Political Economy, 94(4):pp. 691-719.

Hanson, G. H., Mataloni, Raymond J., J., and Slaughter, M. J. (2001). Expansion strategies of u.s. multinational firms. Brookings Trade Forum, pages pp. 245-294.

Hanson, G. H., Mataloni, R. J., and Slaughter, M. J. (2005). Vertical production networks in multinational firms. The Review of Economics and Statistics, 87(4):664678.

Hart, O. and Moore, J. (1990). Property Rights and the Nature of the Firm. Journal of Political Economy, 98(6):1119-58.

Helpman, E. (1984). A simple theory of international trade with multinational corporations. Journal of Political Economy, 92(3):pp. 451-471.

Helpman, E. (2006). Trade, FDI, and the Organization of Firms. Journal of Economic Literature, American Economic Association, 44(3):589-630.

Helpman, E. and Krugman, P. (1985). Market Structure and Foreign Trade. Cambridge, Massachusetts: MIT Press.

Helpman, E., Melitz, M. J., and Yeaple, S. R. (2004). Export Versus FDI with Heterogeneous Firms. American Economic Review, American Economic Association, $94(1): 300-316$.

Horstmann, I. J. and Markusen, J. R. (1992). Endogenous market structures in international trade (natura facit saltum). Journal of International Economics, 32(12):109 -129 . 
Irarrazabal, A., Moxnes, A., and Opromolla, L. D. (2013). The Margins of Multinational Production and the Role of Intrafirm Trade. Journal of Political Economy, 121(1):74 $-126$.

Markusen, J. R. (1984). Multinationals, multi-plant economies, and the gains from trade. Journal of International Economics, 16(3-4):205-226.

Markusen, J. R. and Venables, A. J. (2000). The theory of endowment, intra-industry and multi-national trade. Journal of International Economics, 52(2):209-234.

McGrattan, E. R. and Prescott, E. C. (2010). Technology capital and the us current account. American Economic Review, 100(4):1493-1522.

Melitz, M. J. (2003). The impact of trade on intra-industry reallocations and aggregate industry productivity. Econometrica, 71(6):pp. 1695-1725.

Nunn, N. and Trefler, D. (2013). Incomplete contracts and the boundaries of the multinational firm. Journal of Economic Behavior Organization, 94(0):330 - 344.

OECD (2002). Intra-industry and intra-firm trade and the internationalisation of production. OECD Economic Outlook 71.

Ramondo, N., Rappoport, V., and Ruhl, K. J. (2011). Horizontal Vs. Vertical FDI : Revisiting Evidence from U.S. Multinationals. Technical report.

Ramondo, N., Rappoport, V., and Ruhl, K. J. (2013). The proximity-concentration tradeoff under uncertainty. The Review of Economic Studies, 80(4):1582-1621.

Simon, H. A. (1991). Bounded rationality and organizational learning. Organization Science, 2(1):pp. 125-134.

UNCTAD (1998). World investment report 2010. trends and determinants. United Nations Publication, New York and Geneva.

UNCTAD (2010a). Economic development in africa report 2010. south-south cooperation: Africa and the new forms of development partnership. United Nations Publication, New York and Geneva.

UNCTAD (2010b). World investment report 2010. investing in a low carbon economy. United Nations Publication, New York and Geneva.

UNCTAD (2013). Economic development in africa report 2013. intra-african trade: Unlocking private sector dynamism. United Nations Publication, New York and Geneva.

UNCTAD and UNIDO (2011). Economic development in africa report 2011. fostering industrial development in africa in the new global environment. United Nations Publication, New York and Geneva.

Yeaple, S. R. (2003a). The complex integration strategies of multinationals and cross country dependencies in the structure of foreign direct investment. Journal of International Economics, 60(2):293-314. 
Yeaple, S. R. (2003b). The Role of Skill Endowments in the Structure of U.S. Outward Foreign Direct Investment. The Review of Economics and Statistics, 85(3):726-734.

Yeaple, S. R. (2008). Multinational enterprise and economic analysis, 3rd edition, richard caves. cambridge university press (2007). Journal of International Economics, $75(2): 383-385$. 
Table 14: Description of variables

\begin{tabular}{|c|c|}
\hline Variable & "Description \\
\hline$D_{\text {ift }}$ & the firm has intra-firm trade (imports, exports, or both) (dummy) \\
\hline$D_{\text {ifim }}$ & the firm has intra-firm imports (dummy) \\
\hline$D_{\text {ifex }}$ & the firm has intra-firm exports (dummy) \\
\hline$D_{\text {ifimex }}$ & the firm has both intra-firm imports and exports (dummy) \\
\hline skillInt & $\log$ of skill intensity \\
\hline capInt & $\log$ of capital intensity \\
\hline numEmp & $\log$ of total number of employees (firm size) \\
\hline wageEmp & log of wage per employee \\
\hline labProd & $\log$ of labour productivity \\
\hline & $\log$ of total factor productivity \\
\hline inpInt & $\log$ of input intensity \\
\hline$D_{\text {training }}$ & the firm provides formal internal and/or external training to its employees (dummy) \\
\hline$D_{\text {ifimonly }}$ & the firm has only intra-firm imports (dummy) \\
\hline$D_{\text {ifexonly }}$ & the firm has only intra-firm exports (dummy) \\
\hline$D_{\text {armt }}$ & the firm has only arms' length trade (dummy) \\
\hline$D_{\text {ftrade }}$ & the firm is foreign-owned and has arms' length trade only (dummy) \\
\hline$D_{\text {fnotrade }}$ & firm is foreign-owned and has neither intra-firm nor arms' length trade (dummy) \\
\hline$D_{\text {nofnotrade }}$ & firm is domestic (i.e., not foreign-owned) and has no trade (dummy) \\
\hline$D_{\text {fimponly }}$ & the firm is foreign-owned and has arms' length imports only (dummy) \\
\hline$D_{\text {fexponly }}$ & the firm is foreign-owned and has arms' length exports only (dummy) \\
\hline$D_{\text {fimpexp }}$ & firm is foreign-owned and has arms' length imports and exports (dummy) \\
\hline$D_{\text {trade }}$ & firm has trade (imports, exports, or both) (dummy) \\
\hline$D_{\text {imponly }}$ & firm has only imports (dummy) \\
\hline$D_{\text {exponly }}$ & firm has only exports (dummy) \\
\hline$D_{\text {impexp }}$ & firm has both imports and exports (dummy) \\
\hline $\begin{array}{l}D_{\text {capUnderLowDem }} \\
\text { firmAge }\end{array}$ & $\begin{array}{l}\text { main reason for production capacity under-utilisation: low demand (dummy) } \\
\text { firm age }\end{array}$ \\
\hline$D_{\text {capUnderUnrelSupply }}$ & $\begin{array}{l}\text { main reason for production capacity under-utilisation: unreliable supply of production inputs (raw materials and supplies) } \\
\text { (dummy) }\end{array}$ \\
\hline$D_{\text {capUnderLackSkill }}$ & main reason for production capacity under-utilisation: lack of skilled workers (dummy) \\
\hline$D_{\text {capUnderLackWC }}$ & main reason for production capacity under-utilisation: lack of working capital/credit (dummy) \\
\hline$D_{\text {capUnderLabMarReg }}$ & main reason for production capacity under-utilisation: labour market regulations (dummy) \\
\hline$D_{\text {capUnderLackTech }}$ & main reason for production capacity under-utilisation: lack of specialised technology, machinery and spare-parts (dummy) \\
\hline$D_{\text {capUnderNo }}$ & main reason for production capacity under-utilisation: production capacity not under-utilised (dummy) \\
\hline$D_{\text {perfovBCWellBelow }}$ & company's performance is well below overall expectations for this company before the global financial crisis (dummy) \\
\hline$D_{\text {perfovBCBelow }}$ & company's performance is below overall expectations for this company before the global financial crisis (dummy) \\
\hline$D_{\text {perfovBCInLine }}$ & company's performance is in line with overall expectations for this company before the global financial crisis (dummy) \\
\hline$D_{\text {perfOvBCAbove }}$ & company's performance is above overall expectations for this company before the global financial crisis (dummy) \\
\hline$D_{\text {perfOvBCWellAbove }}$ & company's performance is well above overall expectations for this company before the global financial crisis (dummy) \\
\hline DerfovaCWellBelow & company's performance is well below revised expectations for this company after the global financial crisis (dummy) \\
\hline$D_{\text {perfovACBelow }}$ & company's performance is below revised expectations for this company after the global financial crisis (dummy) \\
\hline$D_{\text {perfovACInLine }}$ & company's performance is in line with revised expectations for this company after the global financial crisis (dummy) \\
\hline$D_{\text {perfovACAbove }}$ & company's performance is above revised expectations for this company after the global financial crisis (dummy) \\
\hline$D_{\text {perfOvaCWellAbove }}$ & company's performance is well above revised expectations for this company after the global financial crisis (dummy) \\
\hline$D_{\text {capUtilNoChange }}$ & no change in capacity utilisation after the global financial crisis (dummy) \\
\hline$D_{\text {caputilDec }}$ & decrease in capacity utilisation after the global financial crisis (dummy) \\
\hline$D_{\text {capUtillnc }}$ & increase in capacity utilisation after the global financial crisis (dummy) \\
\hline$D_{\text {capUtilNoChangeHM }}$ & no change in capacity utilisation after the global financial crisis (higher mean values) (dummy) \\
\hline$D_{\text {capUtilDecHM }}$ & decrease in capacity utilisation after the global financial crisis (higher mean values) (dummy) \\
\hline$D_{\text {capUtillnchM }}$ & increase in capacity utilisation after the global financial crisis (higher mean values) (dummy) \\
\hline$D_{\text {capUtilNoChange } 10 T}$ & no change in capacity utilisation after the global financial crisis ( $10 \%$ tolerance) (dummy) \\
\hline$D_{\text {capUtilDec10T }}$ & decrease in capacity utilisation after the global financial crisis ( $10 \%$ tolerance) (dummy) \\
\hline$D_{\text {capUtillnc } 10 T}$ & increase in capacity utilisation after the global financial crisis (10\% tolerance) (dummy) \\
\hline$D_{\text {capUtil NoChange 20T }}$ & no change in capacity utilisation after the global financial crisis ( $20 \%$ tolerance) (dummy) \\
\hline$D_{\text {capUtilDec } 20 T}$ & decrease in capacity utilisation after the global financial crisis ( $20 \%$ tolerance) (dummy) \\
\hline$D_{\text {capUtillnc } 20 T}$ & increase in capacity utilisation after the global financial crisis ( $20 \%$ tolerance) (dummy) \\
\hline$D_{\text {capUtilNoChange } 30 T}$ & no change in capacity utilisation after the global financial crisis ( $30 \%$ tolerance) (dummy) \\
\hline$D_{\text {capUtilDec } 30 T}$ & decrease in capacity utilisation after the global financial crisis ( $30 \%$ tolerance) (dummy) \\
\hline$D_{\text {capUtillnc } 30 T}$ & increase in capacity utilisation after the global financial crisis ( $30 \%$ tolerance) (dummy) \\
\hline
\end{tabular}


Sotiris Blanas and Adnan Seric

A Appendix: Additional stylised facts 


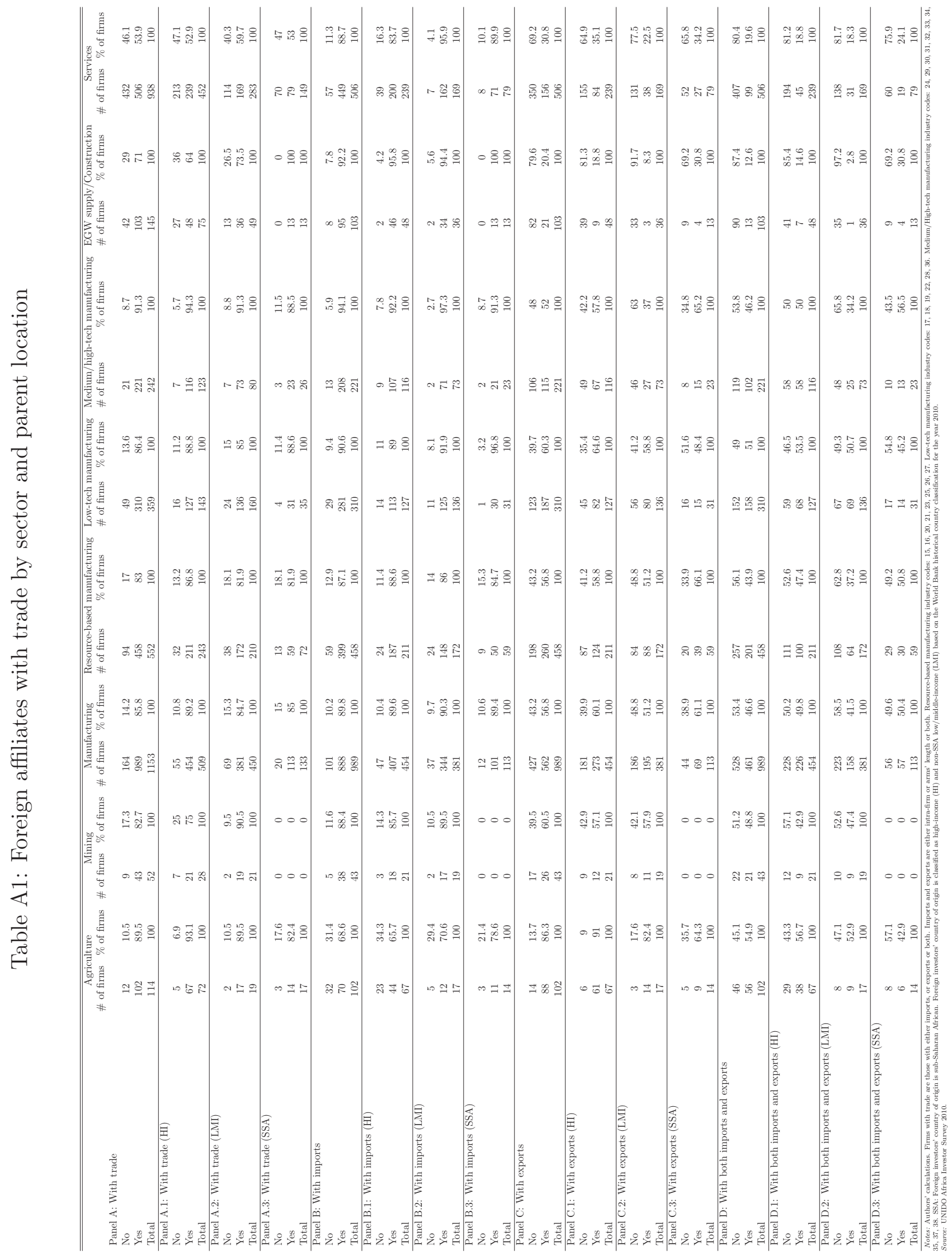




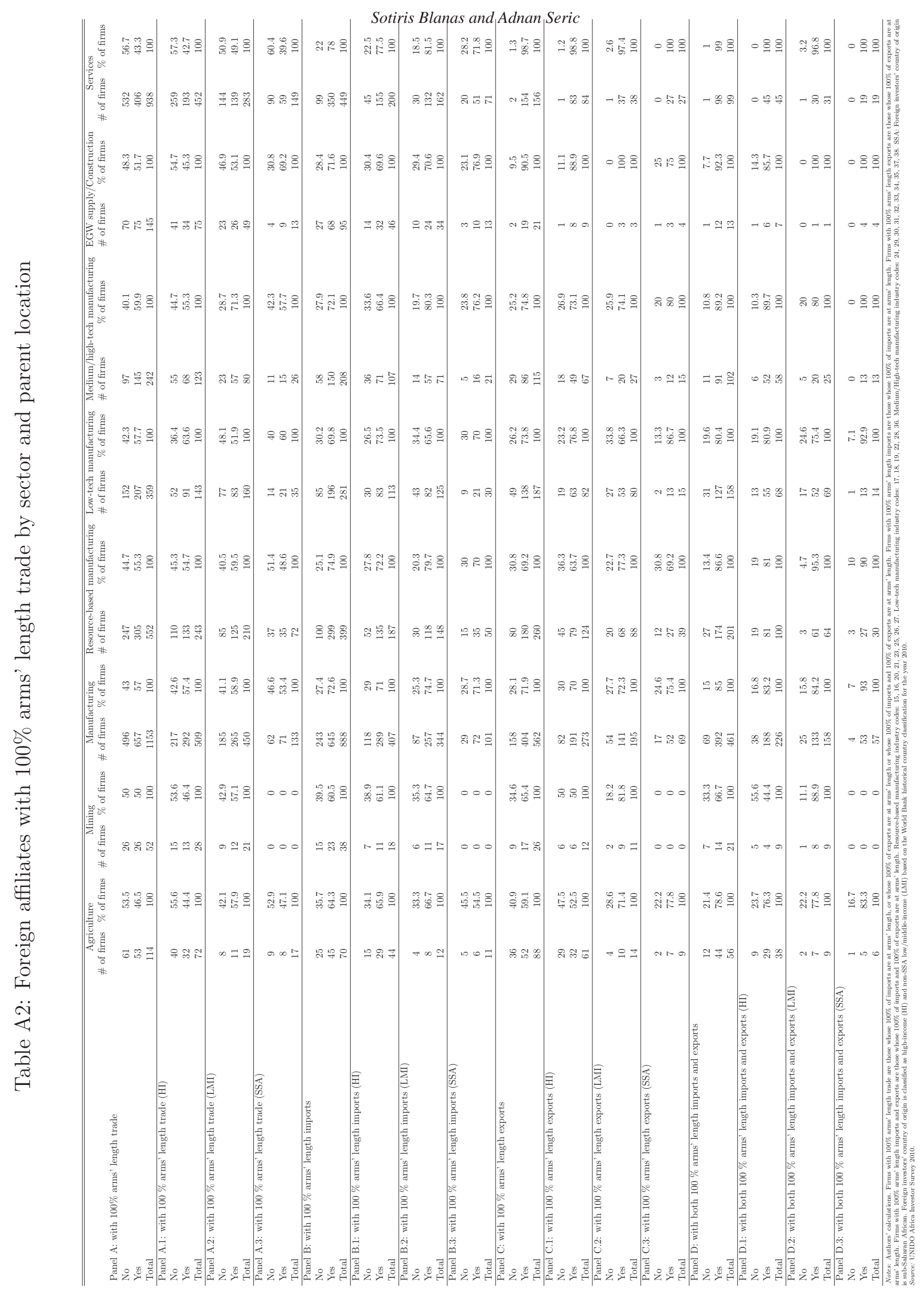


Scarcity, Size and Productivity Advantage of Foreign Affiliates with Intra-Firm Trade

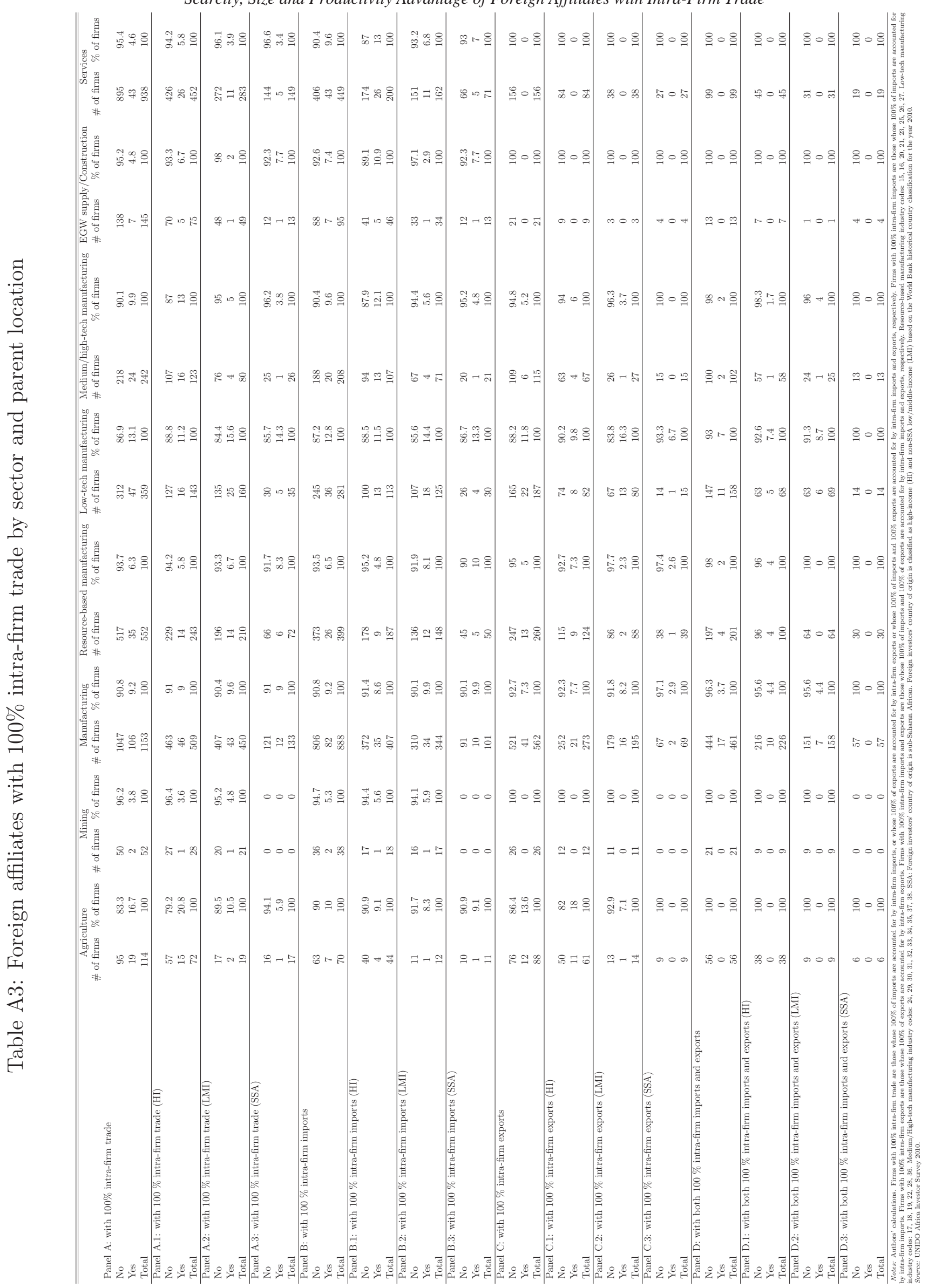


Figure A1: Density of foreign affiliates by total sales

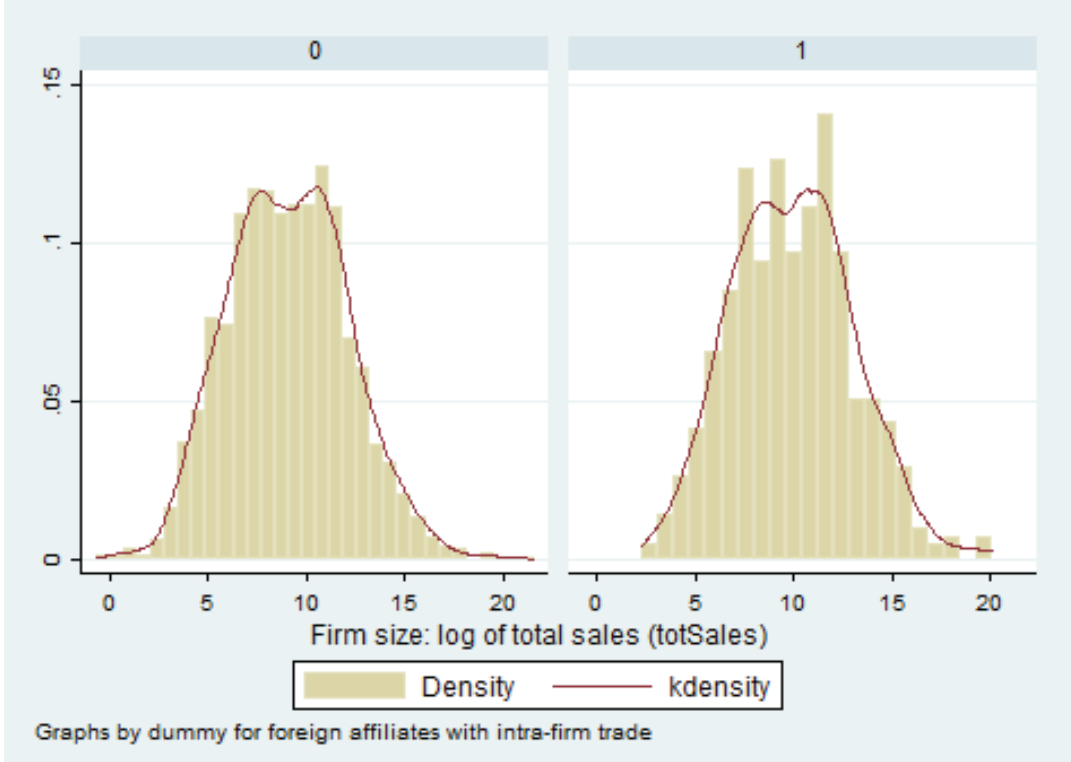

Figure A2: Foreign affiliates by total sales in percentiles

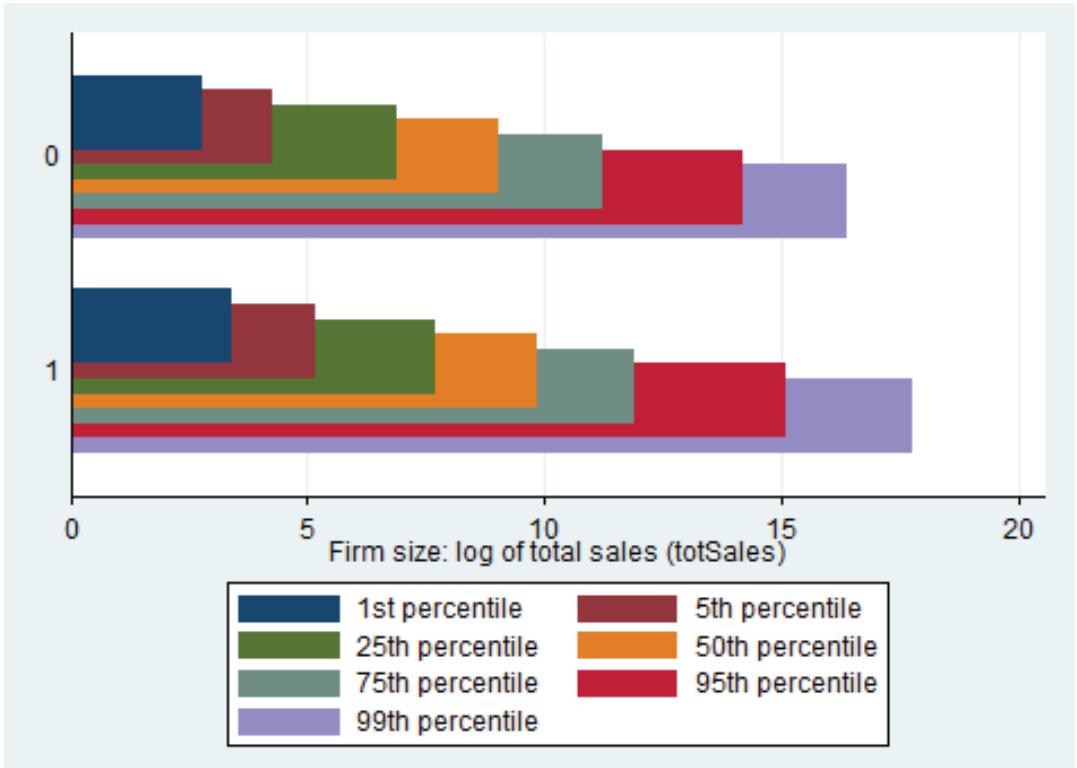


Figure A3: Density of foreign affiliates by total value added to total employment

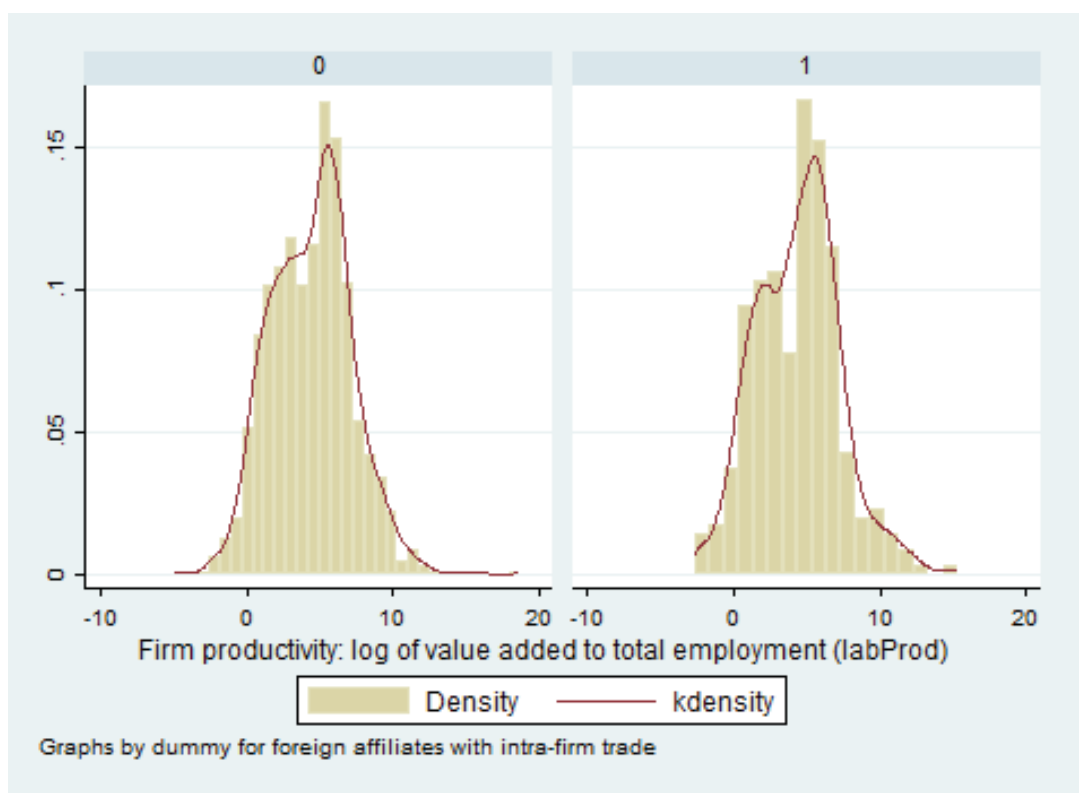

Figure A4: Foreign affiliates by total value added to total employment in percentiles

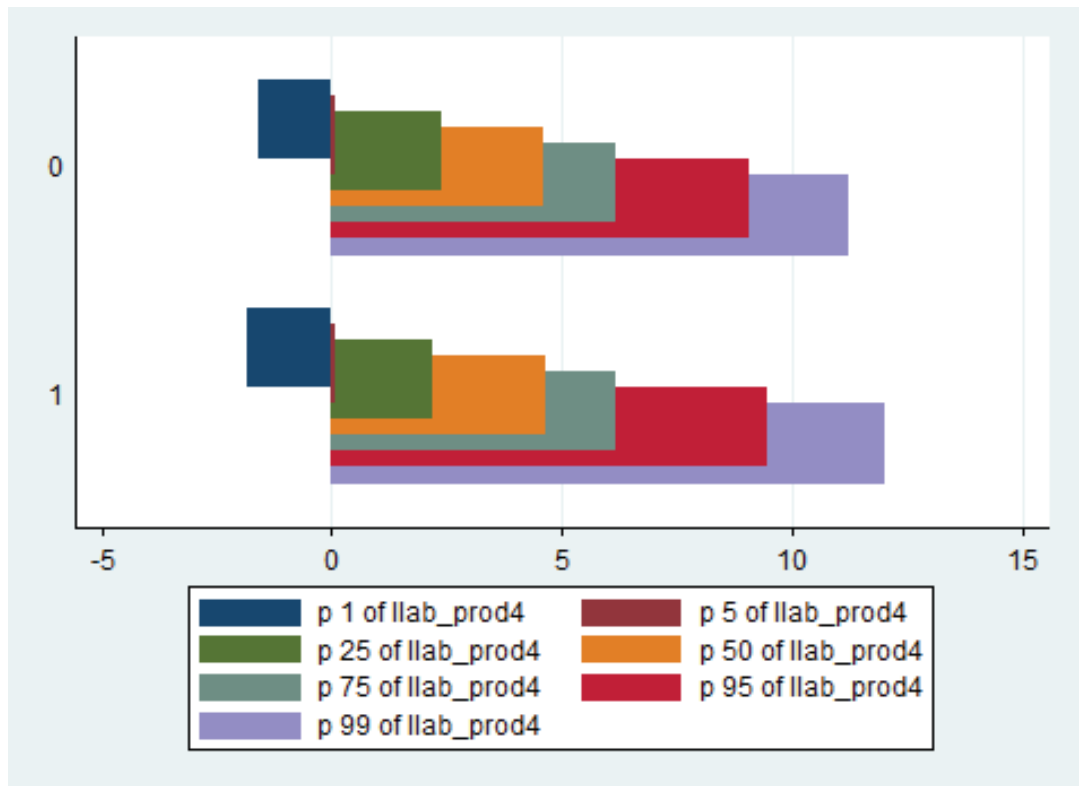


Figure A5: Density of foreign affiliates by total factor productivity

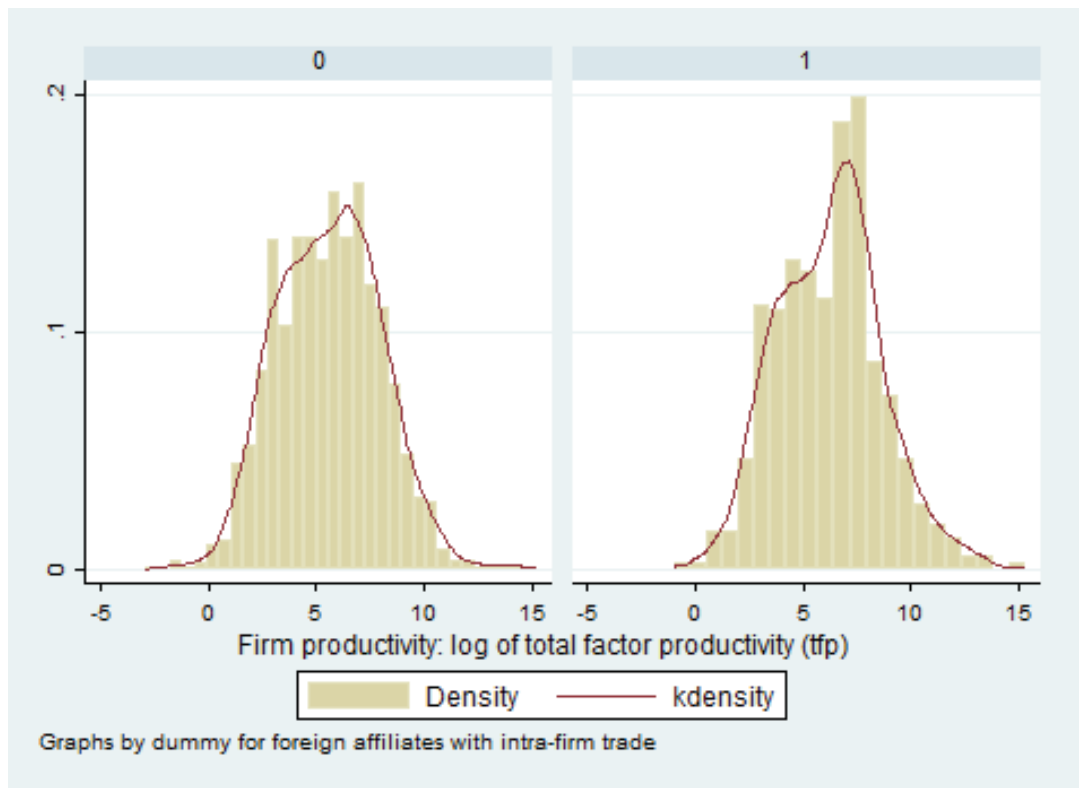

Figure A6: Foreign affiliates by total factor productivity in percentiles

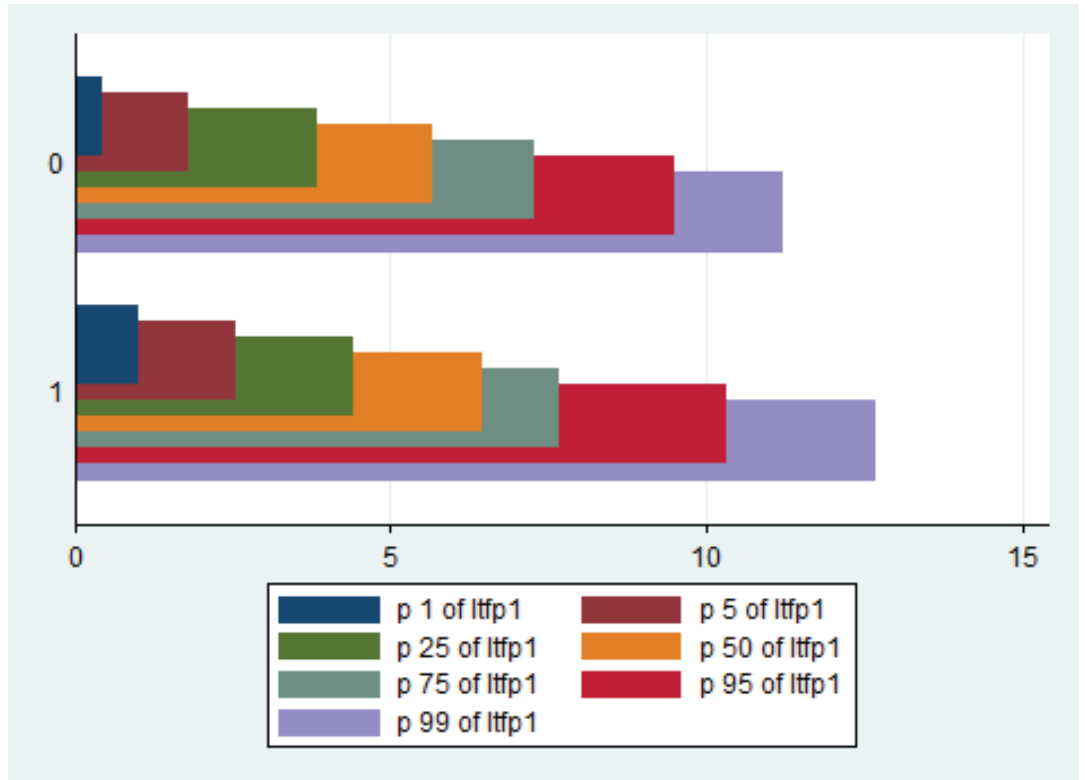




\section{B Appendix: Robustness checks}

Table B1: Main characteristics (Manufacturing sector)

\begin{tabular}{|c|c|c|c|c|c|c|}
\hline & (1) & $\overline{(2)}$ & $\overline{(3)}$ & $\overline{(4)}$ & $\overline{(5)}$ & (6) \\
\hline & $D_{i f t}$ & $D_{i f t}$ & $D_{i f t}$ & $D_{\text {ifex }}$ & $D_{\text {ifim }}$ & $D_{\text {ifimex }}$ \\
\hline skillInt & $\begin{array}{c}-0.0153 \\
{[0.014]}\end{array}$ & $\begin{array}{c}-0.0198 \\
{[0.013]}\end{array}$ & $\begin{array}{c}-0.0169 \\
{[0.014]}\end{array}$ & $\begin{array}{c}-0.00840 \\
{[0.0086]}\end{array}$ & $\begin{array}{c}-0.00241 \\
{[0.012]}\end{array}$ & $\begin{array}{c}-0.00102 \\
{[0.0050]}\end{array}$ \\
\hline capInt & $\begin{array}{c}-0.00580 \\
{[0.0077]}\end{array}$ & $\begin{array}{c}-0.00667 \\
{[0.0076]}\end{array}$ & $\begin{array}{c}-0.00113 \\
{[0.0075]}\end{array}$ & $\begin{array}{c}-0.00179 \\
{[0.0050]}\end{array}$ & $\begin{array}{r}-0.00351 \\
{[0.0065]}\end{array}$ & $\begin{array}{c}-0.000100 \\
{[0.0029]}\end{array}$ \\
\hline numEmp & $\begin{array}{c}0.0476^{* * *} \\
{[0.010]}\end{array}$ & & $\begin{array}{c}0.0283^{* *} \\
{[0.012]}\end{array}$ & $\begin{array}{c}0.0352^{* * *} \\
{[0.0069]}\end{array}$ & $\begin{array}{c}0.0232^{* * *} \\
{[0.0087]}\end{array}$ & $\begin{array}{c}0.0146^{* * *} \\
{[0.0041]}\end{array}$ \\
\hline wageEmp & $\begin{array}{l}0.0170 \\
{[0.012]}\end{array}$ & $\begin{array}{l}0.0148 \\
{[0.011]}\end{array}$ & $\begin{array}{l}0.0147 \\
{[0.012]}\end{array}$ & $\begin{array}{c}0.000245 \\
{[0.0075]}\end{array}$ & $\begin{array}{l}0.0178^{*} \\
{[0.0100]}\end{array}$ & $\begin{array}{l}0.00267 \\
{[0.0044]}\end{array}$ \\
\hline labProd & $\begin{array}{c}0.0332^{* * *} \\
{[0.0099]}\end{array}$ & & & $\begin{array}{c}0.0231^{* * *} \\
{[0.0071]}\end{array}$ & $\begin{array}{c}0.0216^{* *} \\
{[0.0087]}\end{array}$ & $\begin{array}{c}0.0109 * * \\
{[0.0048]}\end{array}$ \\
\hline inpInt & $\begin{array}{l}0.00442 \\
{[0.0080]}\end{array}$ & $\begin{array}{l}0.00132 \\
{[0.0075]}\end{array}$ & $\begin{array}{l}0.00278 \\
{[0.0079]}\end{array}$ & $\begin{array}{c}-0.00233 \\
{[0.0052]}\end{array}$ & $\begin{array}{l}0.00739 \\
{[0.0072]}\end{array}$ & $\begin{array}{l}0.00205 \\
{[0.0033]}\end{array}$ \\
\hline$D_{\text {training }}(\mathrm{d})$ & $\begin{array}{l}0.0219 \\
{[0.023]}\end{array}$ & $\begin{array}{l}0.0241 \\
{[0.023]}\end{array}$ & $\begin{array}{l}0.0187 \\
{[0.023]}\end{array}$ & $\begin{array}{c}-0.0126 \\
{[0.014]}\end{array}$ & $\begin{array}{l}0.0355^{*} \\
{[0.019]}\end{array}$ & $\begin{array}{c}-0.00395 \\
{[0.0088]}\end{array}$ \\
\hline totSales & & $\begin{array}{c}0.0403^{* * *} * \\
{[0.0072]}\end{array}$ & & & & \\
\hline$t f p$ & & & $\begin{array}{c}0.0394^{* * *} \\
{[0.010]}\end{array}$ & & & \\
\hline Obs & 1581 & 1581 & 1580 & 1247 & 1555 & 940 \\
\hline Pseudo - $R^{2}$ & 0.20 & 0.20 & 0.21 & 0.28 & 0.17 & 0.30 \\
\hline Log-likelihood & -730.0 & -730.5 & -728.1 & -382.1 & -644.2 & -194.0 \\
\hline
\end{tabular}


Table B2: Main characteristics (Whole economy - Majority-owned foreign affiliates)

\begin{tabular}{|c|c|c|c|c|c|c|}
\hline & (1) & (2) & (3) & (4) & (5) & (6) \\
\hline & $D_{i f t}$ & $D_{i f t}$ & $D_{i f t}$ & $D_{i f e x}$ & $D_{\text {ifim }}$ & $D_{\text {ifimex }}$ \\
\hline skillInt & $\begin{array}{c}-0.0253^{*} \\
{[0.015]}\end{array}$ & $\begin{array}{c}-0.0274^{*} \\
{[0.014]}\end{array}$ & $\begin{array}{c}-0.0260^{*} \\
{[0.015]}\end{array}$ & $\begin{array}{l}-0.0116 \\
{[0.0085]}\end{array}$ & $\begin{array}{l}-0.0107 \\
{[0.013]}\end{array}$ & $\begin{array}{c}-0.00703 \\
{[0.011]}\end{array}$ \\
\hline capInt & $\begin{array}{c}-0.00335 \\
{[0.0082]}\end{array}$ & $\begin{array}{c}-0.00375 \\
{[0.0082]}\end{array}$ & $\begin{array}{l}0.00200 \\
{[0.0081]}\end{array}$ & $\begin{array}{l}-0.00266 \\
{[0.0050]}\end{array}$ & $\begin{array}{c}-0.00198 \\
{[0.0069]}\end{array}$ & $\begin{array}{c}-0.00367 \\
{[0.0063]}\end{array}$ \\
\hline numEmp & $\begin{array}{c}0.0452^{* * *} \\
{[0.011]}\end{array}$ & & $\begin{array}{c}0.0254^{* *} \\
{[0.013]}\end{array}$ & $\begin{array}{c}0.0313 * * * \\
{[0.0074]}\end{array}$ & $\begin{array}{l}0.0197^{* *} \\
{[0.0095]}\end{array}$ & $\begin{array}{c}0.0245 * * * \\
{[0.0083]}\end{array}$ \\
\hline wageEmp & $\begin{array}{l}0.0156 \\
{[0.013]}\end{array}$ & $\begin{array}{l}0.0144 \\
{[0.012]}\end{array}$ & $\begin{array}{l}0.0149 \\
{[0.013]}\end{array}$ & $\begin{array}{l}0.00326 \\
{[0.0074]}\end{array}$ & $\begin{array}{c}0.0181^{*} \\
{[0.011]}\end{array}$ & $\begin{array}{l}0.0116 \\
{[0.010]}\end{array}$ \\
\hline labProd & $\begin{array}{c}0.0385^{* * *} \\
{[0.011]}\end{array}$ & & & $\begin{array}{c}0.0215^{* * *} \\
{[0.0072]}\end{array}$ & $\begin{array}{c}0.0242^{* * *} * \\
{[0.0092]}\end{array}$ & $\begin{array}{c}0.0221^{* *} \\
{[0.010]}\end{array}$ \\
\hline inpInt & $\begin{array}{l}0.00214 \\
{[0.0084]}\end{array}$ & $\begin{array}{c}0.000702 \\
{[0.0079]}\end{array}$ & $\begin{array}{l}0.00168 \\
{[0.0084]}\end{array}$ & $\begin{array}{c}-0.00225 \\
{[0.0051]}\end{array}$ & $\begin{array}{l}0.00568 \\
{[0.0076]}\end{array}$ & $\begin{array}{l}0.00305 \\
{[0.0066]}\end{array}$ \\
\hline$D_{\text {training }}(\mathrm{d})$ & $\begin{array}{l}0.0279 \\
{[0.024]}\end{array}$ & $\begin{array}{l}0.0289 \\
{[0.024]}\end{array}$ & $\begin{array}{l}0.0249 \\
{[0.024]}\end{array}$ & $\begin{array}{r}-0.0100 \\
{[0.014]}\end{array}$ & $\begin{array}{c}0.0425^{* *} \\
{[0.021]}\end{array}$ & $\begin{array}{c}-0.00569 \\
{[0.019]}\end{array}$ \\
\hline totSales & & $\begin{array}{c}0.0418^{* * *} \\
{[0.0078]}\end{array}$ & & & & \\
\hline$t f p$ & & & $\begin{array}{c}0.0415^{* * *} \\
{[0.011]}\end{array}$ & & & \\
\hline Obs & 1384 & 1384 & 1383 & 1045 & 1364 & 566 \\
\hline Pseudo $-R^{2}$ & 0.2 & 0.22 & 0.2 & 0.31 & 0.1 & 0.28 \\
\hline Log-likelihood & -625.8 & -625.9 & -624.9 & -313.9 & -558.7 & -149.1 \\
\hline
\end{tabular}


Table B3: Main characteristics (Manufacturing sector - Majority-owned foreign affiliates)

\begin{tabular}{|c|c|c|c|c|c|c|}
\hline \multirow{2}{*}{ (7) } & (1) & $(2)$ & (3) & $(4)$ & (5) & $\overline{(6)}$ \\
\hline & $D_{i f t}$ & $D_{i f t}$ & $D_{i f t}$ & $D_{i f e x}$ & $D_{i f i m}$ & $D_{\text {ifimex }}$ \\
\hline \multirow[t]{2}{*}{ skillInt } & -0.0406 & -0.0395 & $-0.0424^{*}$ & -0.0197 & -0.0180 & -0.00773 \\
\hline & {$[0.025]$} & {$[0.024]$} & {$[0.025]$} & {$[0.017]$} & {$[0.021]$} & {$[0.011]$} \\
\hline \multirow[t]{2}{*}{ capInt } & 0.0197 & 0.0200 & $0.0266^{*}$ & 0.00573 & 0.00857 & -0.00409 \\
\hline & {$[0.014]$} & {$[0.014]$} & {$[0.014]$} & {$[0.0097]$} & {$[0.013]$} & {$[0.0064]$} \\
\hline numEmp & $\begin{array}{c}0.0517^{* * *} \\
{[0.019]}\end{array}$ & & $\begin{array}{l}0.0222 \\
{[0.022]}\end{array}$ & $\begin{array}{c}0.0597^{* * *} \\
{[0.014]}\end{array}$ & $\begin{array}{c}0.00468 \\
{[0.016]}\end{array}$ & $\begin{array}{c}0.0189 * * \\
{[0.0094]}\end{array}$ \\
\hline wageEmp & $\begin{array}{l}0.0280 \\
{[0.021]}\end{array}$ & $\begin{array}{l}0.0289 \\
{[0.020]}\end{array}$ & $\begin{array}{l}0.0261 \\
{[0.021]}\end{array}$ & $\begin{array}{l}0.0155 \\
{[0.016]}\end{array}$ & $\begin{array}{l}0.0214 \\
{[0.017]}\end{array}$ & $\begin{array}{l}0.0105 \\
{[0.011]}\end{array}$ \\
\hline labProd & $\begin{array}{c}0.0563^{* *} \\
{[0.022]}\end{array}$ & & & $\begin{array}{c}0.0424^{* *} \\
{[0.017]}\end{array}$ & $\begin{array}{l}0.0303 \\
{[0.020]}\end{array}$ & $\begin{array}{c}0.0276^{* *} \\
{[0.012]}\end{array}$ \\
\hline inpInt & $\begin{array}{l}-0.0195 \\
{[0.018]}\end{array}$ & $\begin{array}{l}-0.0181 \\
{[0.015]}\end{array}$ & $\begin{array}{c}-0.0208 \\
{[0.017]}\end{array}$ & $\begin{array}{l}-0.0207 \\
{[0.013]}\end{array}$ & $\begin{array}{c}0.00627 \\
{[0.015]}\end{array}$ & $\begin{array}{c}-0.00189 \\
{[0.0068]}\end{array}$ \\
\hline$D_{\text {training }}(\mathrm{d})$ & $\begin{array}{l}0.0493 \\
{[0.039]}\end{array}$ & $\begin{array}{l}0.0490 \\
{[0.039]}\end{array}$ & $\begin{array}{l}0.0476 \\
{[0.039]}\end{array}$ & $\begin{array}{c}0.00748 \\
{[0.028]}\end{array}$ & $\begin{array}{c}0.0615^{*} \\
{[0.033]}\end{array}$ & $\begin{array}{l}0.0147 \\
{[0.020]}\end{array}$ \\
\hline totSales & & $\begin{array}{c}0.0537^{* * *} \\
{[0.014]}\end{array}$ & & & & \\
\hline$t f p$ & & & $\begin{array}{c}0.0639^{* * *} \\
{[0.021]}\end{array}$ & & & \\
\hline Obs & 721 & 721 & 719 & 656 & 715 & 433 \\
\hline Pseudo- $R^{2}$ & 0.18 & 0.18 & 0.18 & 0.23 & 0.19 & 0.32 \\
\hline Log-likelihood & -368.5 & -368.6 & -367.2 & -245.4 & -311.2 & -106.2 \\
\hline
\end{tabular}


Table B4: Main characteristics (Drop missing observations of intra-firm trade)

\begin{tabular}{|c|c|c|c|c|c|c|}
\hline & $\overline{(1)}$ & $\overline{(2)}$ & (3) & (4) & 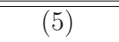 & (6) \\
\hline & $D_{i f t}$ & $D_{i f t}$ & $D_{i f t}$ & $D_{\text {ifex }}$ & $D_{\text {ifim }}$ & $D_{\text {ifimex }}$ \\
\hline \multirow[t]{2}{*}{ skillInt } & -0.0255 & -0.0220 & -0.0293 & -0.0279 & 0.00838 & 0.00978 \\
\hline & {$[0.033]$} & {$[0.031]$} & {$[0.034]$} & {$[0.033]$} & {$[0.028]$} & {$[0.022]$} \\
\hline \multirow[t]{2}{*}{ capInt } & -0.00830 & -0.00741 & 0.00363 & $-0.0394^{* *}$ & 0.0116 & -0.0134 \\
\hline & {$[0.018]$} & {$[0.017]$} & {$[0.017]$} & {$[0.018]$} & {$[0.015]$} & {$[0.012]$} \\
\hline numEmp & $\begin{array}{c}0.0667^{* *} \\
{[0.026]}\end{array}$ & & $\begin{array}{l}0.0238 \\
{[0.028]}\end{array}$ & $\begin{array}{c}0.0880^{* * *} \\
{[0.026]}\end{array}$ & $\begin{array}{l}0.0338 \\
{[0.022]}\end{array}$ & $\begin{array}{c}0.0516^{* * *} \\
{[0.019]}\end{array}$ \\
\hline \multirow[t]{2}{*}{ wageEmp } & 0.0364 & 0.0379 & 0.0361 & 0.0302 & 0.0399 & 0.0273 \\
\hline & {$[0.030]$} & {$[0.029]$} & {$[0.029]$} & {$[0.030]$} & {$[0.026]$} & {$[0.022]$} \\
\hline labProd & $\begin{array}{c}0.0769^{* * *} \\
{[0.027]}\end{array}$ & & & $\begin{array}{c}0.0879 * * * \\
{[0.026]}\end{array}$ & $\begin{array}{c}0.0458^{*} \\
{[0.024]}\end{array}$ & $\begin{array}{c}0.0488^{* *} \\
{[0.020]}\end{array}$ \\
\hline inpInt & $\begin{array}{c}-0.0265 \\
{[0.021]}\end{array}$ & $\begin{array}{c}-0.0236 \\
{[0.020]}\end{array}$ & $\begin{array}{c}-0.0350 \\
{[0.021]}\end{array}$ & $\begin{array}{c}-0.0190 \\
{[0.021]}\end{array}$ & $\begin{array}{c}-0.00308 \\
{[0.017]}\end{array}$ & $\begin{array}{c}0.00717 \\
{[0.012]}\end{array}$ \\
\hline$D_{\text {training }}(\mathrm{d})$ & $\begin{array}{l}-0.0462 \\
{[0.053]}\end{array}$ & $\begin{array}{l}-0.0470 \\
{[0.053]}\end{array}$ & $\begin{array}{l}-0.0529 \\
{[0.053]}\end{array}$ & $\begin{array}{l}-0.0873 \\
{[0.054]}\end{array}$ & $\begin{array}{l}0.0373 \\
{[0.048]}\end{array}$ & $\begin{array}{l}-0.0136 \\
{[0.041]}\end{array}$ \\
\hline totSales & & $\begin{array}{c}0.0713^{* * *} \\
{[0.019]}\end{array}$ & & & & \\
\hline$t f p$ & & & $\begin{array}{c}0.101^{* * *} \\
{[0.026]}\end{array}$ & & & \\
\hline Obs & 493 & 493 & 493 & 473 & 461 & 393 \\
\hline Pseudo- $R^{2}$ & 0.17 & 0.17 & 0.18 & 0.21 & 0.17 & 0.25 \\
\hline Log-likelihood & -282.9 & -283.0 & -280.0 & -246.8 & -230.7 & -146.0 \\
\hline
\end{tabular}


Table B5: Main characteristics (Drop missing observations of intra-firm trade - Manufacturing)

\begin{tabular}{|c|c|c|c|c|c|c|}
\hline & (1) & $\overline{(2)}$ & (3) & $(4)$ & $(5)$ & (6) \\
\hline & $D_{i f t}$ & $D_{i f t}$ & $D_{i f t}$ & $D_{\text {ifex }}$ & $D_{\text {ifim }}$ & $D_{\text {ifimex }}$ \\
\hline \multirow[t]{2}{*}{ skillInt } & -0.0197 & -0.0160 & -0.0228 & -0.0187 & 0.00128 & 0.00663 \\
\hline & {$[0.038]$} & {$[0.036]$} & {$[0.038]$} & {$[0.037]$} & {$[0.032]$} & {$[0.022]$} \\
\hline capInt & $\begin{array}{c}0.00227 \\
{[0.021]}\end{array}$ & $\begin{array}{c}0.00318 \\
{[0.021]}\end{array}$ & $\begin{array}{l}0.0107 \\
{[0.021]}\end{array}$ & $\begin{array}{c}-0.0448^{* *} \\
{[0.020]}\end{array}$ & $\begin{array}{l}0.0173 \\
{[0.018]}\end{array}$ & $\begin{array}{c}-0.0187^{*} \\
{[0.011]}\end{array}$ \\
\hline numEmp & $\begin{array}{c}0.0625^{* *} \\
{[0.031]}\end{array}$ & & $\begin{array}{l}0.0203 \\
{[0.033]}\end{array}$ & $\begin{array}{c}0.0905^{* * *} \\
{[0.031]}\end{array}$ & $\begin{array}{l}0.0210 \\
{[0.028]}\end{array}$ & $\begin{array}{c}0.0424^{* *} \\
{[0.021]}\end{array}$ \\
\hline wageEmp & $\begin{array}{l}0.0461 \\
{[0.034]}\end{array}$ & $\begin{array}{l}0.0481 \\
{[0.033]}\end{array}$ & $\begin{array}{l}0.0461 \\
{[0.034]}\end{array}$ & $\begin{array}{l}0.0488 \\
{[0.036]}\end{array}$ & $\begin{array}{l}0.0355 \\
{[0.029]}\end{array}$ & $\begin{array}{l}0.0208 \\
{[0.021]}\end{array}$ \\
\hline labProd & $\begin{array}{c}0.0750^{* *} \\
{[0.033]}\end{array}$ & & & $\begin{array}{c}0.0916^{* * *} \\
{[0.032]}\end{array}$ & $\begin{array}{c}0.0568^{* *} \\
{[0.029]}\end{array}$ & $\begin{array}{c}0.0562^{* * *} \\
{[0.020]}\end{array}$ \\
\hline inpInt & $\begin{array}{c}-0.0514^{*} \\
{[0.028]}\end{array}$ & $\begin{array}{c}-0.0478^{*} \\
{[0.025]}\end{array}$ & $\begin{array}{c}-0.0562^{* *} \\
{[0.028]}\end{array}$ & $\begin{array}{c}-0.0370 \\
{[0.026]}\end{array}$ & $\begin{array}{c}-0.0274 \\
{[0.021]}\end{array}$ & $\begin{array}{c}-0.0102 \\
{[0.012]}\end{array}$ \\
\hline$D_{\text {training }}(\mathrm{d})$ & $\begin{array}{c}-0.00647 \\
{[0.059]}\end{array}$ & $\begin{array}{c}-0.00763 \\
{[0.059]}\end{array}$ & $\begin{array}{c}-0.00593 \\
{[0.059]}\end{array}$ & $\begin{array}{c}-0.0455 \\
{[0.060]}\end{array}$ & $\begin{array}{l}0.0662 \\
{[0.055]}\end{array}$ & $\begin{array}{l}0.0152 \\
{[0.039]}\end{array}$ \\
\hline totSales & & $\begin{array}{c}0.0681 * * * \\
{[0.023]}\end{array}$ & & & & \\
\hline$t f p$ & & & $\begin{array}{c}0.0935^{* * *} \\
{[0.031]}\end{array}$ & & & \\
\hline Obs & 401 & 401 & 401 & 382 & 366 & 306 \\
\hline Pseudo $-R^{2}$ & 0.18 & 0.18 & 0.18 & 0.22 & 0.20 & 0.29 \\
\hline Log-likelihood & -226.6 & -226.6 & -225.0 & -191.5 & -177.9 & -101.1 \\
\hline 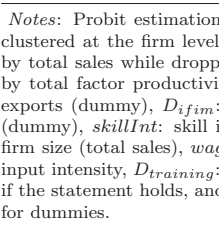 & & & and in & ummies & $\begin{array}{l}\text { olumns. } \\
\text { total emp }\end{array}$ & $\begin{array}{l}\text { lard errors are } \\
\text { ent is replaced } \\
\text { ity is replaced } \\
\text { has intra-firm } \\
\text { ts and exports } \\
\text { es), numEmp: } \\
\text { tivity, inpInt: }\end{array}$ \\
\hline
\end{tabular}


Sotiris Blanas and Adnan Seric

Table B6: Main characteristics (Drop missing observations of intra-firm trade - MOFAs)

\begin{tabular}{|c|c|c|c|c|c|c|}
\hline & (1) & (2) & (3) & (4) & (5) & (6) \\
\hline & $D_{i f t}$ & $D_{i f t}$ & $D_{i f t}$ & $D_{\text {ifex }}$ & $D_{\text {ifim }}$ & $D_{\text {ifimex }}$ \\
\hline skillInt & $\begin{array}{c}-0.0532 \\
{[0.037]}\end{array}$ & $\begin{array}{c}-0.0502 \\
{[0.034]}\end{array}$ & $\begin{array}{c}-0.0595 \\
{[0.038]}\end{array}$ & $\begin{array}{c}-0.0501 \\
{[0.036]}\end{array}$ & $\begin{array}{c}-0.00210 \\
{[0.032]}\end{array}$ & $\begin{array}{c}-0.00117 \\
{[0.023]}\end{array}$ \\
\hline capInt & $\begin{array}{c}-0.00968 \\
{[0.020]}\end{array}$ & $\begin{array}{c}-0.00880 \\
{[0.019]}\end{array}$ & $\begin{array}{l}0.00189 \\
{[0.019]}\end{array}$ & $\begin{array}{c}-0.0383^{*} \\
{[0.020]}\end{array}$ & $\begin{array}{c}-0.000918 \\
{[0.017]}\end{array}$ & $\begin{array}{c}-0.0257^{* *} \\
{[0.013]}\end{array}$ \\
\hline numEmp & $\begin{array}{c}0.0669^{* *} \\
{[0.029]}\end{array}$ & & $\begin{array}{l}0.0227 \\
{[0.031]}\end{array}$ & $\begin{array}{c}0.0850^{* * *} \\
{[0.028]}\end{array}$ & $\begin{array}{l}0.0233 \\
{[0.026]}\end{array}$ & $\begin{array}{c}0.0442^{* *} \\
{[0.020]}\end{array}$ \\
\hline wage Emp & $\begin{array}{c}0.0601^{*} \\
{[0.034]}\end{array}$ & $\begin{array}{c}0.0614^{*} \\
{[0.034]}\end{array}$ & $\begin{array}{c}0.0588^{*} \\
{[0.034]}\end{array}$ & $\begin{array}{l}0.0516 \\
{[0.034]}\end{array}$ & $\begin{array}{c}0.0512^{*} \\
{[0.030]}\end{array}$ & $\begin{array}{c}0.0413^{*} \\
{[0.024]}\end{array}$ \\
\hline labProd & $\begin{array}{c}0.0757^{* * *} \\
{[0.029]}\end{array}$ & & & $\begin{array}{c}0.0856^{* * *} \\
{[0.029]}\end{array}$ & $\begin{array}{c}0.0431^{*} \\
{[0.026]}\end{array}$ & $\begin{array}{c}0.0503^{* *} \\
{[0.020]}\end{array}$ \\
\hline inpInt & $\begin{array}{l}-0.0200 \\
{[0.023]}\end{array}$ & $\begin{array}{l}-0.0177 \\
{[0.021]}\end{array}$ & $\begin{array}{l}-0.0345 \\
{[0.023]}\end{array}$ & $\begin{array}{l}-0.0118 \\
{[0.022]}\end{array}$ & $\begin{array}{c}-0.00227 \\
{[0.019]}\end{array}$ & $\begin{array}{c}0.00571 \\
{[0.012]}\end{array}$ \\
\hline$D_{\text {training }}(\mathrm{d})$ & $\begin{array}{c}-0.0106 \\
{[0.058]}\end{array}$ & $\begin{array}{l}-0.0114 \\
{[0.058]}\end{array}$ & $\begin{array}{l}-0.0214 \\
{[0.059]}\end{array}$ & $\begin{array}{l}-0.0657 \\
{[0.057]}\end{array}$ & $\begin{array}{l}0.0592 \\
{[0.054]}\end{array}$ & $\begin{array}{c}0.00349 \\
{[0.044]}\end{array}$ \\
\hline totSales & & $\begin{array}{c}0.0710^{* * *} \\
{[0.021]}\end{array}$ & & & & \\
\hline$t f p$ & & & $\begin{array}{c}0.113^{* * *} \\
{[0.028]}\end{array}$ & & & \\
\hline Obs & 418 & 418 & 418 & 411 & 373 & 318 \\
\hline Pseudo- $R^{2}$ & 0.18 & 0.18 & 0.20 & 0.22 & 0.15 & 0.26 \\
\hline Log-likelihood & -236.2 & -236.3 & -232.2 & -210.8 & -194.8 & -118.9 \\
\hline
\end{tabular}


Table B7: Main characteristics (Drop missing observations of intra-firm trade - MOFAs in Manufacturing)

\begin{tabular}{|c|c|c|c|c|c|c|}
\hline & (1) & (2) & 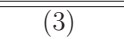 & 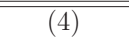 & 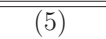 & $\overline{~(6))}$ \\
\hline & $D_{i f t}$ & $D_{i f t}$ & $D_{i f t}$ & $D_{i f e x}$ & $D_{\text {ifim }}$ & $D_{\text {ifimex }}$ \\
\hline \multirow[t]{2}{*}{ skillInt } & -0.0563 & -0.0522 & -0.0618 & -0.0504 & -0.0159 & -0.00887 \\
\hline & {$[0.042]$} & {$[0.040]$} & {$[0.042]$} & {$[0.039]$} & {$[0.036]$} & {$[0.020]$} \\
\hline \multirow[t]{2}{*}{ capInt } & 0.00247 & 0.00363 & 0.00839 & $-0.0414^{* *}$ & 0.00870 & $-0.0267 * *$ \\
\hline & {$[0.022]$} & {$[0.022]$} & {$[0.023]$} & {$[0.020]$} & {$[0.021]$} & {$[0.011]$} \\
\hline \multirow[t]{2}{*}{ numEmp } & 0.0490 & & 0.00857 & $0.0745^{* *}$ & -0.0111 & 0.0238 \\
\hline & {$[0.035]$} & & {$[0.037]$} & [0.033] & {$[0.033]$} & {$[0.022]$} \\
\hline \multirow[t]{2}{*}{ wageEmp } & $0.0788^{*}$ & $0.0814^{* *}$ & $0.0750^{*}$ & $0.0807^{*}$ & 0.0494 & $0.0367^{*}$ \\
\hline & {$[0.042]$} & {$[0.040]$} & {$[0.042]$} & {$[0.042]$} & {$[0.034]$} & {$[0.021]$} \\
\hline \multirow[t]{2}{*}{ labProd } & $0.0636^{*}$ & & & $0.0779 * *$ & 0.0470 & $0.0531 * * *$ \\
\hline & {$[0.034]$} & & & {$[0.033]$} & [0.033] & {$[0.020]$} \\
\hline \multirow[t]{2}{*}{ inpInt } & -0.0343 & -0.0301 & -0.0470 & -0.0148 & -0.0162 & 0.00417 \\
\hline & [0.029] & {$[0.026]$} & {$[0.029]$} & {$[0.026]$} & {$[0.023]$} & {$[0.011]$} \\
\hline \multirow[t]{2}{*}{$D_{\text {training }}(\mathrm{d})$} & 0.0439 & 0.0422 & 0.0415 & -0.0114 & $0.109^{*}$ & 0.0407 \\
\hline & {$[0.065]$} & {$[0.065]$} & {$[0.065]$} & {$[0.063]$} & {$[0.060]$} & {$[0.040]$} \\
\hline totSales & & $\begin{array}{c}0.0558^{* *} \\
{[0.025]}\end{array}$ & & & & \\
\hline$t f p$ & & & $\begin{array}{c}0.0976^{* * *} \\
{[0.033]}\end{array}$ & & & \\
\hline Obs & 336 & 336 & 336 & 330 & 297 & 252 \\
\hline Pseudo $-R^{2}$ & 0.19 & 0.19 & 0.20 & 0.23 & 0.19 & 0.32 \\
\hline Log-likelihood & -187.0 & -187.1 & -184.6 & -162.7 & -146.5 & -80.0 \\
\hline \multicolumn{7}{|c|}{ 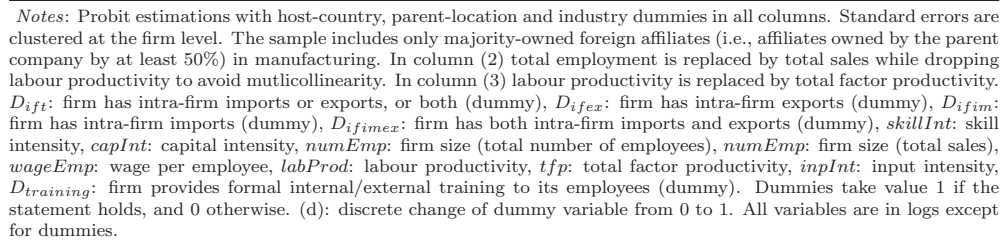 } \\
\hline
\end{tabular}


Sotiris Blanas and Adnan Seric

Table B8: Main characteristics (control for firm age)

\begin{tabular}{|c|c|c|c|c|c|c|}
\hline & (1) & 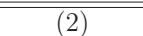 & (3) & (4) & (5) & (6) \\
\hline & $D_{i f t}$ & $D_{i f t}$ & $D_{i f t}$ & $D_{\text {ifex }}$ & $D_{\text {ifim }}$ & $D_{\text {ifimex }}$ \\
\hline \multirow[t]{2}{*}{ skillInt } & -0.0148 & -0.0195 & -0.0164 & -0.00915 & -0.00198 & -0.00161 \\
\hline & {$[0.014]$} & {$[0.013]$} & {$[0.014]$} & {$[0.0086]$} & {$[0.012]$} & {$[0.0050]$} \\
\hline \multirow[t]{2}{*}{ capInt } & -0.00616 & -0.00710 & -0.00152 & -0.00233 & -0.00371 & -0.000514 \\
\hline & {$[0.0077]$} & {$[0.0076]$} & {$[0.0076]$} & {$[0.0050]$} & {$[0.0065]$} & {$[0.0029]$} \\
\hline \multirow[t]{2}{*}{ numEmp } & $0.0479^{* * *}$ & & $0.0289^{* *}$ & $0.0327^{* * *}$ & $0.0239 * * *$ & $0.0127^{* * *}$ \\
\hline & {$[0.011]$} & & {$[0.012]$} & {$[0.0069]$} & {$[0.0090]$} & [0.0041] \\
\hline \multirow[t]{2}{*}{ wageEmp } & 0.0173 & 0.0148 & 0.0150 & -0.000688 & $0.0181^{*}$ & 0.00216 \\
\hline & {$[0.012]$} & {$[0.011]$} & {$[0.012]$} & {$[0.0075]$} & {$[0.010]$} & {$[0.0044]$} \\
\hline labProd & $\begin{array}{c}0.0329^{* * *} \\
{[0.0100]}\end{array}$ & & & $\begin{array}{c}0.0228^{* * *} \\
{[0.0071]}\end{array}$ & $\begin{array}{c}0.0215^{* *} \\
{[0.0087]}\end{array}$ & $\begin{array}{c}0.0105^{* *} \\
{[0.0047]}\end{array}$ \\
\hline \multirow[t]{2}{*}{ inpInt } & 0.00489 & 0.00175 & 0.00314 & -0.00207 & 0.00760 & 0.00217 \\
\hline & {$[0.0080]$} & {$[0.0075]$} & {$[0.0079]$} & {$[0.0052]$} & [0.0072] & {$[0.0032]$} \\
\hline$D_{\text {training }}(\mathrm{d})$ & $\begin{array}{l}0.0222 \\
{[0.023]}\end{array}$ & $\begin{array}{l}0.0243 \\
{[0.023]}\end{array}$ & $\begin{array}{l}0.0190 \\
{[0.023]}\end{array}$ & $\begin{array}{l}-0.0126 \\
{[0.014]}\end{array}$ & $\begin{array}{c}0.0356^{*} \\
{[0.019]}\end{array}$ & $\begin{array}{c}-0.00380 \\
{[0.0087]}\end{array}$ \\
\hline firmAge & $\begin{array}{c}-0.00321 \\
{[0.017]}\end{array}$ & $\begin{array}{c}-0.0000734 \\
{[0.016]}\end{array}$ & $\begin{array}{c}-0.00464 \\
{[0.017]}\end{array}$ & $\begin{array}{l}0.0122 \\
{[0.010]}\end{array}$ & $\begin{array}{c}-0.00521 \\
{[0.014]}\end{array}$ & $\begin{array}{l}0.00930 \\
{[0.0063]}\end{array}$ \\
\hline totSales & & $\begin{array}{c}0.0401^{* * *} * \\
{[0.0073]}\end{array}$ & & & & \\
\hline$t f p$ & & & $\begin{array}{c}0.0394^{* * *} \\
{[0.010]}\end{array}$ & & & \\
\hline Obs & 1575 & 1575 & 1574 & 1244 & 1549 & 938 \\
\hline Pseudo $-R^{2}$ & 0.20 & 0.20 & 0.21 & 0.29 & 0.17 & 0.30 \\
\hline Log-likelihood & -728.2 & -728.7 & -726.3 & -380.8 & -643.0 & -192.8 \\
\hline $\begin{array}{l}\text { Notes: Probit estimatiol } \\
\text { tered at the firm level. } \\
\text { mutlicollinearity. In colur } \\
\text { exports, or both (dummy } \\
\text { firm has both intra-firm } \\
\text { (total number of employe } \\
\text { tfp: total factor producti } \\
\text { (dummy). Dummies take } \\
\text { All variables are in logs e }\end{array}$ & $\begin{array}{l}\text { e } 1 \text { i the } \\
\text { for dum }\end{array}$ & $\begin{array}{l}\text { arent-loca } \\
\text { loyment } \\
\text { ity is repp } \\
\text { firm exp } \\
\text { ummy), } \\
\text { ze (total } \\
\text { nsity, }, D_{t r}\end{array}$ & $\begin{array}{l}\text { Immyl, } \\
\text { : skill in } \\
\text { wagem } \\
\text { firm pro }\end{array}$ & $\begin{array}{l}\text { nmies in all } \\
\text { les while dr } \\
\text { roductivity. } \\
\text { firm has int } \\
\text { f capInt: ca } \\
\text { gee per empl } \\
\text { ormal intern }\end{array}$ & $\begin{array}{l}\text { mns. Stand } \\
\text { gl labour pr } \\
\text { : firm has in } \\
\text { rm imports } \\
\text { lintensity, } \\
\text { labProd: } \\
\text { ternal train }\end{array}$ & $\begin{array}{l}\text { errors are clus } \\
\text { ctivity to avoic } \\
\text { firm imports o } \\
\text { amy), } D_{\text {ifimex }} \\
\text { Emp: firm siz } \\
\text { ir productivity } \\
\text { o its employee } \\
\text { le from } 0 \text { to } 1\end{array}$ \\
\hline
\end{tabular}


Table B9: Main characteristics (logit model)

\begin{tabular}{|c|c|c|c|c|c|c|}
\hline & (1) & (2) & (3) & (4) & (5) & (6) \\
\hline & $D_{i f t}$ & $D_{i f t}$ & $D_{i f t}$ & $D_{\text {ifex }}$ & $D_{\text {ifim }}$ & $D_{\text {ifimex }}$ \\
\hline \multirow[t]{2}{*}{ skillInt } & -0.103 & -0.130 & -0.114 & -0.126 & -0.0296 & -0.00604 \\
\hline & {$[0.089]$} & {$[0.085]$} & {$[0.089]$} & {$[0.12]$} & {$[0.098]$} & {$[0.17]$} \\
\hline \multirow[t]{2}{*}{ capInt } & -0.0387 & -0.0443 & -0.0108 & -0.0196 & -0.0298 & 0.00740 \\
\hline & {$[0.049]$} & {$[0.048]$} & {$[0.048]$} & {$[0.074]$} & {$[0.053]$} & {$[0.11]$} \\
\hline numEmp & $\begin{array}{c}0.289^{* * *} \\
{[0.066]}\end{array}$ & & $\begin{array}{c}0.170^{* *} \\
{[0.074]}\end{array}$ & $\begin{array}{c}0.495^{* * *} \\
{[0.095]}\end{array}$ & $\begin{array}{c}0.181^{* * *} \\
{[0.070]}\end{array}$ & $\begin{array}{c}0.523^{* * *} \\
{[0.13]}\end{array}$ \\
\hline \multirow[t]{2}{*}{ wage Emp } & 0.104 & 0.0884 & 0.0878 & 0.0181 & $0.136^{*}$ & 0.128 \\
\hline & {$[0.076]$} & {$[0.074]$} & {$[0.077]$} & {$[0.11]$} & {$[0.081]$} & {$[0.17]$} \\
\hline labProd & $\begin{array}{c}0.201^{* * *} \\
{[0.064]}\end{array}$ & & & $\begin{array}{c}0.328^{* * *} \\
{[0.11]}\end{array}$ & $\begin{array}{c}0.164^{* *} \\
{[0.070]}\end{array}$ & $\begin{array}{c}0.380^{* *} \\
{[0.18]}\end{array}$ \\
\hline inpInt & $\begin{array}{l}0.0268 \\
{[0.050]}\end{array}$ & $\begin{array}{c}0.00805 \\
{[0.047]}\end{array}$ & $\begin{array}{l}0.0153 \\
{[0.050]}\end{array}$ & $\begin{array}{c}-0.0418 \\
{[0.075]}\end{array}$ & $\begin{array}{l}0.0606 \\
{[0.058]}\end{array}$ & $\begin{array}{l}0.0526 \\
{[0.11]}\end{array}$ \\
\hline$D_{\text {training }}$ & $\begin{array}{l}0.138 \\
{[0.14]}\end{array}$ & $\begin{array}{l}0.152 \\
{[0.14]}\end{array}$ & $\begin{array}{l}0.116 \\
{[0.14]}\end{array}$ & $\begin{array}{l}-0.181 \\
{[0.21]}\end{array}$ & $\begin{array}{c}0.280^{*} \\
{[0.16]}\end{array}$ & $\begin{array}{c}-0.0906 \\
{[0.31]}\end{array}$ \\
\hline \multicolumn{2}{|l|}{ totSales } & $\begin{array}{c}0.246^{* * *} \\
{[0.045]}\end{array}$ & & & & \\
\hline \multicolumn{2}{|l|}{$t f p$} & & $\begin{array}{c}0.245^{* * *} \\
{[0.065]}\end{array}$ & & & \\
\hline Obs & 1581 & 1581 & 1580 & 1247 & 1555 & 940 \\
\hline Pseudo $-R^{2}$ & 0.20 & 0.20 & 0.21 & 0.29 & 0.17 & 0.31 \\
\hline Log-likelihood & -730.1 & -730.6 & -728.0 & -380.6 & -644.5 & -191.8 \\
\hline $\begin{array}{l}\text { Notes: Logit estimation } \\
\text { are clustered at the firm } \\
\text { productivity to avoid mu } \\
D_{\text {ifft }} \text { firm has intra-firm } \\
\text { firm has intra-firm import } \\
\text { intensity, capInt: capital } \\
\text { wageEmemp: wage per emp } \\
\text { Dtraining: firm provides } \\
\text { take value } 1 \text { if the statem } \\
\text { are in logs except for dum }\end{array}$ & $\begin{array}{l}\text { host-ce } \\
\text { In co }\end{array}$ & $\begin{array}{l}\text { parent-1 } \\
\text { 2) total }\end{array}$ & $\begin{array}{l}\text { intra- } \\
\text { numbe } \\
\text { tffp: } \\
\text { its em }\end{array}$ & $\begin{array}{l}\text { ports a } \\
\text { ployees } \\
\text { ctor pr } \\
\text { (dum } \\
\text { dumm }\end{array}$ & $\begin{array}{l}\text { l columns } \\
\text { ales while } \\
\text { y total fa } \\
\text { 1 exports } \\
\text { ths (dumn } \\
\text { Emp: firn } \\
\text { ty, inpIn } \\
\text { mAge: fit } \\
\text { le from } 0\end{array}$ & $\begin{array}{l}\text { andard errors } \\
\text { ping labour } \\
\text { productivity. } \\
\text { may), Difim: } \\
\text { sillintint: skill } \\
\text { (total sales, } \\
\text { put intensity, } \\
\text { pe. Dummies } \\
\text { All variables }\end{array}$ \\
\hline
\end{tabular}


Sotiris Blanas and Adnan Seric

Table B10: Main characteristics (linear probability model)

\begin{tabular}{|c|c|c|c|c|c|c|}
\hline & (1) & (2) & (3) & (4) & (5) & (6) \\
\hline & $D_{i f t}$ & $D_{i f t}$ & $D_{i f t}$ & $D_{i f e x}$ & $D_{\text {ifim }}$ & $D_{\text {ifimex }}$ \\
\hline \multirow[t]{2}{*}{ skillInt } & -0.00860 & -0.0134 & -0.00994 & -0.00577 & 0.000543 & 0.00337 \\
\hline & {$[0.013]$} & {$[0.012]$} & {$[0.013]$} & [0.0093] & {$[0.012]$} & {$[0.0072]$} \\
\hline \multirow[t]{2}{*}{ capInt } & -0.00773 & -0.00840 & -0.00358 & -0.00287 & -0.00668 & -0.00182 \\
\hline & {$[0.0070]$} & {$[0.0070]$} & {$[0.0069]$} & {$[0.0052]$} & {$[0.0067]$} & {$[0.0040]$} \\
\hline \multirow[t]{2}{*}{ numEmp } & $0.0432 * * *$ & & $0.0269 * *$ & $0.0353^{* * *}$ & $0.0258 * * *$ & $0.0179 * * *$ \\
\hline & {$[0.0096]$} & & {$[0.011]$} & {$[0.0070]$} & {$[0.0090]$} & {$[0.0053]$} \\
\hline \multirow[t]{2}{*}{ wageEmp } & 0.0143 & 0.0120 & 0.0116 & 0.000178 & $0.0169^{*}$ & 0.00275 \\
\hline & {$[0.011]$} & {$[0.011]$} & {$[0.011]$} & {$[0.0086]$} & {$[0.010]$} & {$[0.0066]$} \\
\hline \multirow{2}{*}{ labProd } & $0.0281^{* * *}$ & & & $0.0176^{* * *}$ & $0.0201^{* *}$ & $0.00963^{* *}$ \\
\hline & {$[0.0085]$} & & & {$[0.0059]$} & {$[0.0082]$} & {$[0.0047]$} \\
\hline \multirow{2}{*}{ inpInt } & 0.00618 & 0.00337 & 0.00469 & -0.000732 & 0.00984 & 0.00292 \\
\hline & {$[0.0073]$} & {$[0.0071]$} & {$[0.0073]$} & {$[0.0054]$} & {$[0.0074]$} & {$[0.0048]$} \\
\hline \multirow[t]{2}{*}{$D_{\text {training }}$} & 0.0138 & 0.0160 & 0.0116 & -0.0237 & 0.0311 & -0.00637 \\
\hline & {$[0.022]$} & {$[0.022]$} & {$[0.022]$} & {$[0.016]$} & {$[0.021]$} & {$[0.011]$} \\
\hline \multicolumn{2}{|l|}{ totSales } & $\begin{array}{c}0.0353^{* * *} \\
{[0.0063]}\end{array}$ & & & & \\
\hline \multicolumn{2}{|l|}{$t f p$} & & $\begin{array}{c}0.0335^{* * *} \\
{[0.0086]}\end{array}$ & & & \\
\hline Obs & 1741 & 1741 & 1740 & 1741 & 1741 & 1741 \\
\hline$R^{2}$ & 0.16 & 0.16 & 0.16 & 0.15 & 0.11 & 0.077 \\
\hline $\begin{array}{l}\text { Notes: Linear P } \\
\text { dard errors are } \\
\text { labour productiv } \\
D_{\text {ift }} \text { : firm has in } \\
\text { firm has intra-fir } \\
\text { intensity, capInt } \\
\text { wageEmp: wage } \\
D_{\text {training }} \text { : firm } \\
\text { statement holds. }\end{array}$ & $\begin{array}{l}\text { ability estim } \\
\text { ered at the } \\
\text { o a avoid mut } \\
\text { firm import } \\
\text { nports (dum } \\
\text { pital intensi }\end{array}$ & $\begin{array}{l}\text { ns with host- } \\
\text { level. In co } \\
\text { inearity. In } \\
\text { exports, or } \\
D_{\text {iffimex: }} \text { : } \\
\text { umEmp: fir }\end{array}$ & $\begin{array}{l}\text { try, parent- } \\
\text { (2) total e } \\
\text { in (3) labou } \\
\text { (dummy), } \\
\text { as both int } \\
\text { e (total nur }\end{array}$ & $\begin{array}{l}\text { ion and ind } \\
\text { yment is re } \\
\text { ductivity is } \\
x \text { : firm has } \\
\text { m imports } \\
\text { of employee } \\
\text { tal factor p }\end{array}$ & $\begin{array}{l}\text { dummies in } \\
1 \text { by total sa } \\
\text { ed by total } \\
\text { firm exports } \\
\text { cports (dum } \\
\text { «mEmp: fir } \\
\text { tivity, } \text { inpI } \\
\text { Dummies }\end{array}$ & $\begin{array}{l}\text { olumns. St } \\
\text { while droppi } \\
\text { r productivi } \\
\text { mmy), } D_{i f i} \\
\text { skillint: sl } \\
\text { e (total sale } \\
\text { nput intensi }\end{array}$ \\
\hline
\end{tabular}


Table B11: Main characteristics (dummies for parent located in HI, non-SSA LMI, SSA countries)

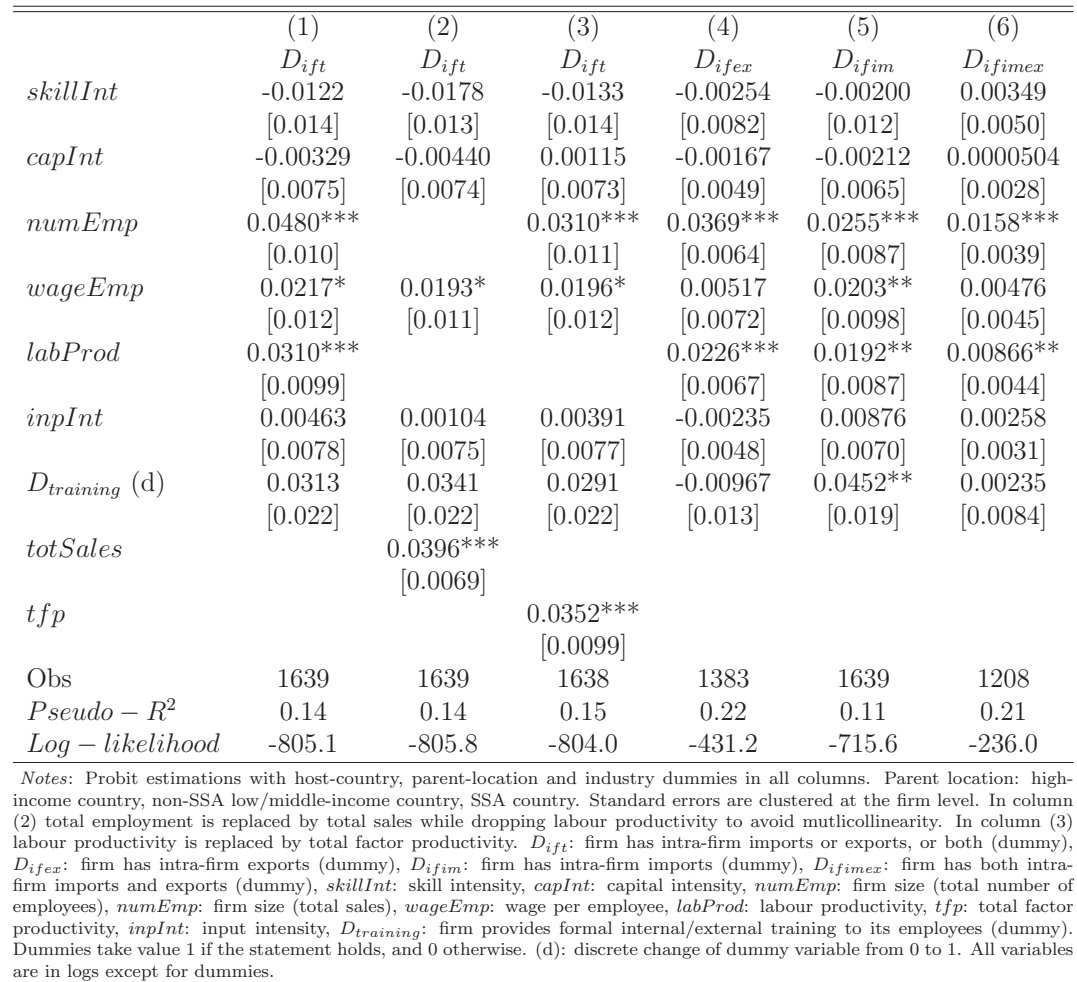


Table B12: Main characteristics (dummies for pairs of host countries and industries)

\begin{tabular}{|c|c|c|c|c|c|c|}
\hline & (1) & (2) & (3) & (4) & (5) & $(6)$ \\
\hline & $D_{i f t}$ & $D_{i f t}$ & $D_{i f t}$ & $D_{\text {ifex }}$ & $D_{\text {ifim }}$ & $D_{\text {ifimex }}$ \\
\hline \multirow[t]{2}{*}{ skillInt } & -0.0278 & -0.0370 & -0.0316 & 0.00154 & -0.0170 & 0.0105 \\
\hline & {$[0.025]$} & {$[0.024]$} & {$[0.025]$} & {$[0.026]$} & {$[0.023]$} & {$[0.020]$} \\
\hline \multirow[t]{2}{*}{ capInt } & -0.00270 & -0.00470 & 0.00452 & 0.00516 & 0.000319 & 0.00681 \\
\hline & {$[0.013]$} & {$[0.012]$} & {$[0.012]$} & {$[0.015]$} & {$[0.012]$} & {$[0.012]$} \\
\hline numEmp & $\begin{array}{c}0.0764^{* * *} \\
{[0.018]}\end{array}$ & & $\begin{array}{c}0.0456^{* *} \\
{[0.019]}\end{array}$ & $\begin{array}{c}0.100^{* * *} \\
{[0.020]}\end{array}$ & $\begin{array}{c}0.0380^{* *} \\
{[0.016]}\end{array}$ & $\begin{array}{c}0.0684^{* * *} \\
{[0.015]}\end{array}$ \\
\hline \multirow[t]{2}{*}{ wageEmp } & 0.0186 & 0.0149 & 0.0147 & -0.00766 & $0.0307^{*}$ & 0.0243 \\
\hline & {$[0.019]$} & {$[0.019]$} & {$[0.019]$} & {$[0.023]$} & {$[0.018]$} & {$[0.016]$} \\
\hline labProd & $\begin{array}{c}0.0512^{* * *} \\
{[0.017]}\end{array}$ & & & $\begin{array}{l}0.0355^{*} \\
{[0.021]}\end{array}$ & $\begin{array}{c}0.0375^{* *} \\
{[0.017]}\end{array}$ & $\begin{array}{l}0.0171 \\
{[0.019]}\end{array}$ \\
\hline \multirow[t]{2}{*}{ inpInt } & 0.0141 & 0.00899 & 0.0113 & 0.0183 & 0.00999 & 0.0130 \\
\hline & {$[0.012]$} & {$[0.012]$} & {$[0.012]$} & {$[0.016]$} & {$[0.012]$} & {$[0.012]$} \\
\hline$D_{\text {training }}(\mathrm{d})$ & $\begin{array}{l}0.0228 \\
{[0.036]}\end{array}$ & $\begin{array}{l}0.0259 \\
{[0.036]}\end{array}$ & $\begin{array}{l}0.0156 \\
{[0.036]}\end{array}$ & $\begin{array}{l}-0.0550 \\
{[0.039]}\end{array}$ & $\begin{array}{c}0.0690^{* *} \\
{[0.034]}\end{array}$ & $\begin{array}{l}-0.0149 \\
{[0.032]}\end{array}$ \\
\hline totSales & & $\begin{array}{c}0.0634^{* * *} \\
{[0.013]}\end{array}$ & & & & \\
\hline$t f p$ & & & $\begin{array}{c}0.0619^{* * *} \\
{[0.017]}\end{array}$ & & & \\
\hline Obs & 977 & 977 & 976 & 573 & 924 & 363 \\
\hline Pseudo $-R^{2}$ & 0.18 & 0.18 & 0.18 & 0.25 & 0.18 & 0.30 \\
\hline Log-likelihood & -522.1 & -522.6 & -519.3 & -251.2 & -452.4 & -116.2 \\
\hline
\end{tabular}


Table B13: Production capacity under-utilisation

\begin{tabular}{|c|c|c|c|c|c|c|c|}
\hline 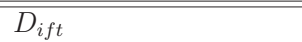 & $\overline{(1)}$ & $\overline{(2)}$ & (3) & $(4)$ & $(5)$ & (6) & $\overline{(7)}$ \\
\hline skillInt & -0.0156 & -0.0150 & -0.0156 & -0.0153 & -0.0151 & -0.0153 & -0.0136 \\
\hline & {$[0.014]$} & {$[0.014]$} & {$[0.014]$} & {$[0.014]$} & {$[0.014]$} & {$[0.014]$} & [0.014] \\
\hline capInt & -0.00579 & -0.00581 & -0.00563 & -0.00589 & -0.00592 & -0.00582 & -0.00609 \\
\hline & {$[0.0077]$} & {$[0.0077]$} & {$[0.0077]$} & {$[0.0077]$} & {$[0.0077]$} & {$[0.0077]$} & {$[0.0077]$} \\
\hline numEmp & $0.0474^{* * *}$ & $0.0476 * * *$ & $0.0478^{* * *}$ & $0.0480^{* * *}$ & $0.0479 * * *$ & $0.0476^{* * *}$ & $0.0471^{* * *}$ \\
\hline & {$[0.010]$} & {$[0.010]$} & {$[0.010]$} & {$[0.010]$} & {$[0.010]$} & {$[0.010]$} & {$[0.010]$} \\
\hline wageEmp & 0.0169 & 0.0172 & 0.0177 & 0.0170 & 0.0172 & 0.0170 & 0.0152 \\
\hline & {$[0.012]$} & {$[0.012]$} & {$[0.012]$} & {$[0.012]$} & {$[0.012]$} & {$[0.012]$} & {$[0.012]$} \\
\hline labProd & $\begin{array}{c}0.0330^{* * *} \\
{[0.0099]}\end{array}$ & $\begin{array}{c}0.0334^{* * *} \\
{[0.0099]}\end{array}$ & $\begin{array}{c}0.0334^{* * *} \\
{[0.0099]}\end{array}$ & $\begin{array}{c}0.0334^{* * *} \\
{[0.0099]}\end{array}$ & $\begin{array}{c}0.0333^{* * *} \\
{[0.0099]}\end{array}$ & $\begin{array}{c}0.0332^{* * *} \\
{[0.0099]}\end{array}$ & $\begin{array}{c}0.0332^{* * *} \\
{[0.0099]}\end{array}$ \\
\hline inpInt & 0.00458 & 0.00422 & 0.00412 & 0.00440 & 0.00434 & 0.00442 & 0.00440 \\
\hline & {$[0.0080]$} & {$[0.0080]$} & {$[0.0080]$} & {$[0.0080]$} & {$[0.0080]$} & {$[0.0080]$} & [0.0080] \\
\hline$D_{\text {training }}(\mathrm{d})$ & $\begin{array}{l}0.0206 \\
{[0.023]}\end{array}$ & $\begin{array}{l}0.0216 \\
{[0.023]}\end{array}$ & $\begin{array}{l}0.0198 \\
{[0.023]}\end{array}$ & $\begin{array}{l}0.0224 \\
{[0.023]}\end{array}$ & $\begin{array}{l}0.0217 \\
{[0.023]}\end{array}$ & $\begin{array}{l}0.0221 \\
{[0.023]}\end{array}$ & $\begin{array}{l}0.0237 \\
{[0.023]}\end{array}$ \\
\hline$D_{\text {capUnderLowDem }}(\mathrm{d})$ & $\begin{array}{l}-0.0239 \\
{[0.024]}\end{array}$ & & & & & & \\
\hline$D_{\text {capUnderUnrelSupply }}(\mathrm{d})$ & & $\begin{array}{l}0.0300 \\
{[0.037]}\end{array}$ & & & & & \\
\hline$D_{\text {capUnderLackSkill }}(\mathrm{d})$ & & & $\begin{array}{l}0.0785 \\
{[0.070]}\end{array}$ & & & & \\
\hline$D_{\text {capUnderLackWC }}(\mathrm{d})$ & & & & $\begin{array}{l}0.0263 \\
{[0.060]}\end{array}$ & & & \\
\hline$D_{\text {capUnderLabMarReg }}(\mathrm{d})$ & & & & & $\begin{array}{c}-0.0304 \\
{[0.073]}\end{array}$ & & \\
\hline$D_{\text {capUnderLackTech }}(\mathrm{d})$ & & & & & & $\begin{array}{c}-0.00794 \\
{[0.054]}\end{array}$ & \\
\hline$D_{\text {capUnderNo }}(\mathrm{d})$ & & & & & & & $\begin{array}{c}0.0676^{*} \\
{[0.036]}\end{array}$ \\
\hline Obs & 1581 & 1581 & 1581 & 1581 & 1581 & 1581 & 1581 \\
\hline Pseudo $-R^{2}$ & 0.21 & 0.21 & 0.21 & 0.21 & 0.21 & 0.20 & 0.21 \\
\hline Log-likelihood & -729.6 & -729.6 & -729.3 & -729.9 & -729.9 & -730.0 & -728.0 \\
\hline
\end{tabular}


Table B14: Performance before the crisis

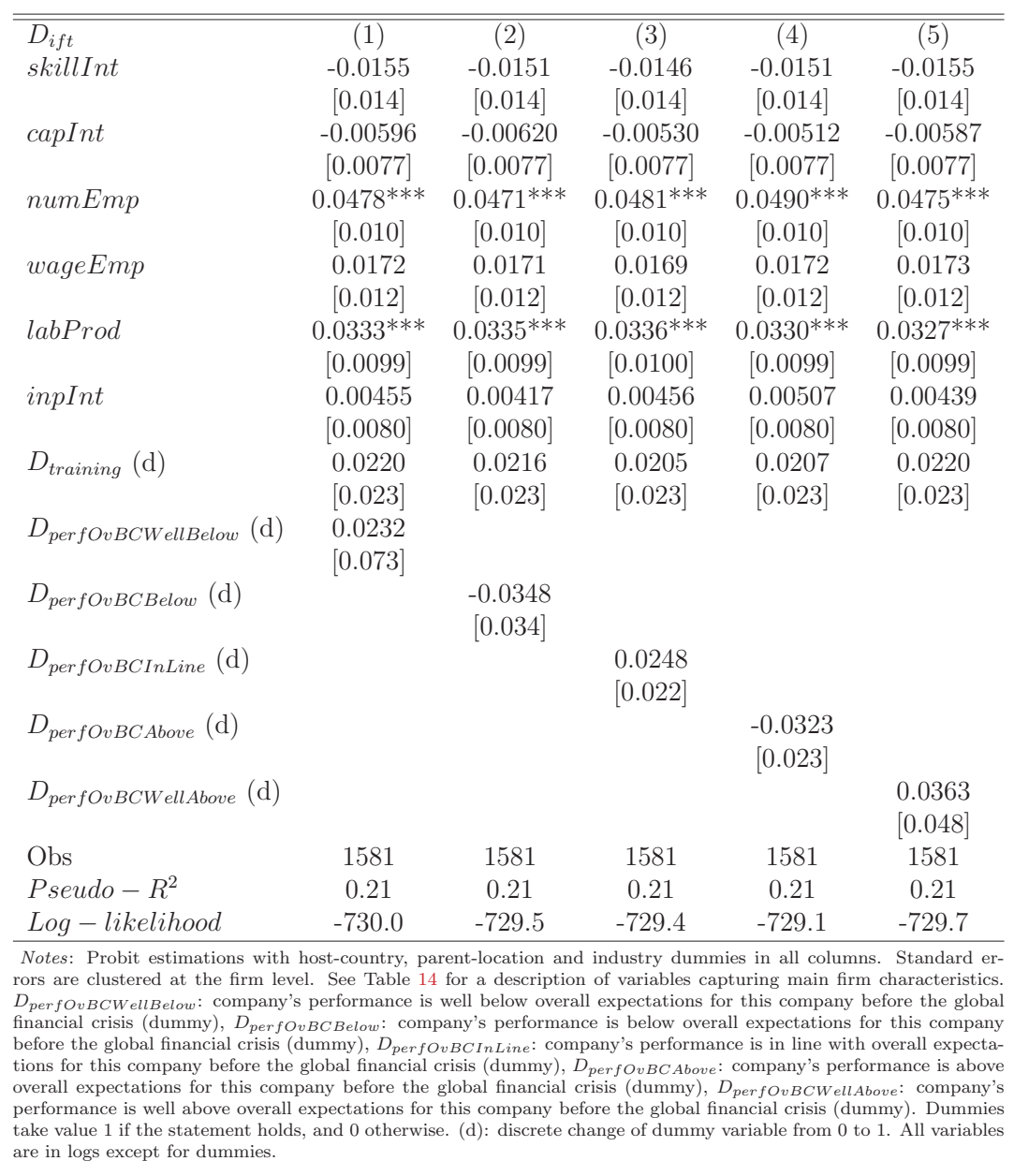


Table B15: Performance after the crisis

\begin{tabular}{|c|c|c|c|c|c|}
\hline 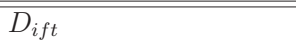 & $\overline{(11)}$ & $\overline{(2)}$ & 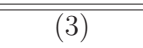 & (4) & 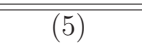 \\
\hline skillInt & $\begin{array}{r}-0.0171 \\
{[0.014]}\end{array}$ & $\begin{array}{r}-0.0155 \\
{[0.014]}\end{array}$ & $\begin{array}{r}-0.0153 \\
{[0.014]}\end{array}$ & -0.0154 & -0.0159 \\
\hline capInt & $\begin{array}{l}{[0.014]} \\
-0.00565 \\
{[0.0077]}\end{array}$ & $\begin{array}{l}{[0.014]} \\
-0.00567 \\
{[0.0077]}\end{array}$ & $\begin{array}{c}{[0.014]} \\
-0.00583 \\
{[0.0077]}\end{array}$ & $\begin{array}{c}{[0.014]} \\
-0.00582 \\
{[0.0077]}\end{array}$ & $\begin{array}{l}{[0.0058]} \\
-0.00581 \\
{[0.0077]}\end{array}$ \\
\hline numEmp & $\begin{array}{c}0.0456 * * * \\
{[0.010]}\end{array}$ & $\begin{array}{c}0.0478^{* * *} \\
{[0.010]}\end{array}$ & $\begin{array}{c}0.0475 * * * \\
{[0.010]}\end{array}$ & $\begin{array}{c}0.0478^{* * *} \\
{[0.010]}\end{array}$ & $\begin{array}{c}0.0476^{* * *} \\
{[0.010]}\end{array}$ \\
\hline wageEmp & $\begin{array}{l}0.0169 \\
{[0.012]}\end{array}$ & $\begin{array}{l}0.0172 \\
{[0.012]}\end{array}$ & $\begin{array}{l}0.0171 \\
{[0.012]}\end{array}$ & $\begin{array}{l}0.0172 \\
{[0.012]}\end{array}$ & $\begin{array}{l}0.0168 \\
{[0.012]}\end{array}$ \\
\hline labProd & $\begin{array}{c}0.0330^{* * *} * \\
{[0.0100]}\end{array}$ & $\begin{array}{c}0.0333^{* * *} \\
{[0.0099]}\end{array}$ & $\begin{array}{c}0.0333^{* * *} * \\
{[0.0099]}\end{array}$ & $\begin{array}{c}0.0335^{* * *} \\
{[0.0099]}\end{array}$ & $\begin{array}{c}0.0328 * * * \\
{[0.0099]}\end{array}$ \\
\hline inpInt & $\begin{array}{l}0.00433 \\
{[0.0080]}\end{array}$ & $\begin{array}{l}0.00441 \\
{[0.0080]}\end{array}$ & $\begin{array}{l}0.00438 \\
{[0.0080]}\end{array}$ & $\begin{array}{l}0.00434 \\
{[0.0080]}\end{array}$ & $\begin{array}{l}0.00463 \\
{[0.0080]}\end{array}$ \\
\hline$D_{\text {training }}(\mathrm{d})$ & $\begin{array}{l}0.0212 \\
{[0.023]}\end{array}$ & $\begin{array}{l}0.0213 \\
{[0.023]}\end{array}$ & $\begin{array}{l}0.0219 \\
{[0.023]}\end{array}$ & $\begin{array}{l}0.0211 \\
{[0.023]}\end{array}$ & $\begin{array}{l}0.0210 \\
{[0.023]}\end{array}$ \\
\hline$D_{\text {perfovACWellBelow }}(\mathrm{d})$ & $\begin{array}{c}-0.0797^{*} \\
{[0.043]}\end{array}$ & & & & \\
\hline$D_{\text {perfOvACBelow }}(\mathrm{d})$ & & $\begin{array}{l}0.0129 \\
{[0.027]}\end{array}$ & & & \\
\hline$D_{\text {perfOvACInLine }}(\mathrm{d})$ & & & $\begin{array}{l}0.00370 \\
{[0.022]}\end{array}$ & & \\
\hline$D_{\text {perfOvaCAbove }}(\mathrm{d})$ & & & & $\begin{array}{c}-0.0135 \\
{[0.025]}\end{array}$ & \\
\hline$D_{\text {perfOvACWellAbove }}(\mathrm{d})$ & & & & & $\begin{array}{l}0.0653 \\
{[0.071]}\end{array}$ \\
\hline Obs & 1581 & 1581 & 1581 & 1581 & 1581 \\
\hline Pseudo- $R^{2}$ & 0.21 & 0.21 & 0.21 & 0.21 & 0.21 \\
\hline Log-likelihood & -728.6 & -729.9 & -730.0 & -729.9 & -729.6 \\
\hline $\begin{array}{l}\text { tes: Probit estimations wi } \\
\text { are clustered at the firm } \\
\text { erfovACW ellBelow: compar } \\
\text { ancial crisis (dummy), } D_{\text {perf }} \\
\text { the global financial crisis (d } \\
\text { this company after the glob } \\
\text { ectations for this company a } \\
\text { vell above revised expectatio } \\
\text { statement holds, and } 0 \text { oth } \\
\text { ept for dummies. }\end{array}$ & $\begin{array}{l}\text { elow: cor } \\
\text { D perfo } \\
\text { icial crisi } \\
\text { eglobal fi } \\
\text { this comp }\end{array}$ & $\begin{array}{l}\text { location } \\
\text { a descrip } \\
\text { below re } \\
\text { performa } \\
n e: \text { comp } \\
\text { y) } D_{\text {per }} \\
\text { risis (du } \\
\text { r the glo }\end{array}$ & $\begin{array}{l}\text { ustry du } \\
\text { variables } \\
\text { ppectatio } \\
\text { elow rev } \\
\text { erforman } \\
\text { bove: col } \\
\text { perfor } f(x) \\
\text { cial cris }\end{array}$ & $\begin{array}{l}\text { in all colu } \\
\text { ing main } \\
\text { his compa } \\
\text { ectations f } \\
\text { line with r } \\
\text { performa } \\
\text { Above: com } \\
\text { my). Dum }\end{array}$ & $\begin{array}{l}\text { Standard er- } \\
\text { aracteristics. } \\
\text { er the global } \\
\text { company af- } \\
\text { expectations } \\
\text { above revised } \\
\text { performance } \\
\text { ake value } 1 \text { if } \\
\text { es are in logs }\end{array}$ \\
\hline
\end{tabular}


Table B16: Financial crisis effect: change in capacity utilisation

\begin{tabular}{|c|c|c|c|}
\hline$\overline{D_{i f t}}$ & $\overline{(1)}$ & $(2)$ & $(3)$ \\
\hline skillInt & $\begin{array}{l}-0.0151 \\
{[0.014]}\end{array}$ & $\begin{array}{l}-0.0147 \\
{[0.014]}\end{array}$ & $\begin{array}{l}-0.0151 \\
{[0.014]}\end{array}$ \\
\hline capInt & $\begin{array}{c}-0.00600 \\
{[0.0077]}\end{array}$ & $\begin{array}{c}-0.00586 \\
{[0.0077]}\end{array}$ & $\begin{array}{c}-0.00640 \\
{[0.0077]}\end{array}$ \\
\hline numEmp & $\begin{array}{c}0.0479 * * * \\
{[0.010]}\end{array}$ & $\begin{array}{c}0.0479^{* * *} \\
{[0.010]}\end{array}$ & $\begin{array}{c}0.0475 * * * \\
{[0.010]}\end{array}$ \\
\hline wageEmp & $\begin{array}{l}0.0172 \\
{[0.012]}\end{array}$ & $\begin{array}{l}0.0174 \\
{[0.012]}\end{array}$ & $\begin{array}{l}0.0170 \\
{[0.012]}\end{array}$ \\
\hline labProd & $\begin{array}{c}0.0334^{* * *} \\
{[0.0099]}\end{array}$ & $\begin{array}{c}0.0337^{* * *} \\
{[0.0099]}\end{array}$ & $\begin{array}{c}0.0331^{* * *} \\
{[0.0100]}\end{array}$ \\
\hline inpInt & $\begin{array}{l}0.00463 \\
{[0.0080]}\end{array}$ & $\begin{array}{l}0.00406 \\
{[0.0080]}\end{array}$ & $\begin{array}{l}0.00499 \\
{[0.0080]}\end{array}$ \\
\hline$D_{\text {training }}(\mathrm{d})$ & $\begin{array}{l}0.0222 \\
{[0.023]}\end{array}$ & $\begin{array}{l}0.0221 \\
{[0.023]}\end{array}$ & $\begin{array}{l}0.0222 \\
{[0.023]}\end{array}$ \\
\hline$D_{\text {capUtilNoChange }}(\mathrm{d})$ & $\begin{array}{l}-0.0233 \\
{[0.025]}\end{array}$ & & \\
\hline$D_{\text {capUtilDec }}(\mathrm{d})$ & & $\begin{array}{l}0.0242 \\
{[0.025]}\end{array}$ & \\
\hline$D_{\text {capUtilInc }}(\mathrm{d})$ & & & $\begin{array}{l}0.0559 \\
{[0.049]}\end{array}$ \\
\hline Obs & 1581 & 1581 & 1581 \\
\hline Pseudo $-R^{2}$ & 0.21 & 0.21 & 0.21 \\
\hline Log-likelihood & -729.6 & -729.5 & -729.3 \\
\hline $\begin{array}{l}\text { Notes: Probit estimations } \\
\text { mies in all columns. St } \\
\text { Table } 14 \text { for a descriptio } \\
D_{\text {caputtilNochange: no ch }} \\
\text { crisis (dummy), } D_{\text {capUtil }} \\
\text { financial crisis (dummy), } \\
\text { global financial crisis (dum } \\
0 \text { otherwise. (d): discrete } \\
\text { are in logs except for dumb }\end{array}$ & count & & dustry \\
\hline
\end{tabular}


Table B17: Financial crisis effect: change in capacity utilisation with higher mean values

\begin{tabular}{|c|c|c|c|}
\hline$D_{i f t}$ & (1) & (2) & (3) \\
\hline \multirow[t]{2}{*}{ skillInt } & -0.0151 & -0.0151 & -0.0147 \\
\hline & {$[0.014]$} & {$[0.014]$} & {$[0.014]$} \\
\hline \multirow[t]{2}{*}{ capInt } & -0.00600 & -0.00640 & -0.00586 \\
\hline & [0.0077] & {$[0.0077]$} & [0.0077] \\
\hline \multirow[t]{2}{*}{ numEmp } & $0.0479 * * *$ & $0.0475 * * *$ & $0.0479 * * *$ \\
\hline & {$[0.010]$} & {$[0.010]$} & {$[0.010]$} \\
\hline \multirow[t]{2}{*}{ wageEmp } & 0.0172 & 0.0170 & 0.0174 \\
\hline & {$[0.012]$} & {$[0.012]$} & {$[0.012]$} \\
\hline \multirow[t]{2}{*}{ labProd } & $0.0334^{* * *}$ & $0.0331^{* * *}$ & $0.0337^{* * *}$ \\
\hline & [0.0099] & [0.0100] & [0.0099] \\
\hline \multirow[t]{2}{*}{ inpInt } & 0.00463 & 0.00499 & 0.00406 \\
\hline & [0.0080] & [0.0080] & [0.0080] \\
\hline \multirow[t]{2}{*}{$D_{\text {training }}(\mathrm{d})$} & 0.0222 & 0.0222 & 0.0221 \\
\hline & {$[0.023]$} & {$[0.023]$} & {$[0.023]$} \\
\hline \multirow[t]{2}{*}{$D_{\text {capUtilNoChangeHM }}$ (d) } & -0.0233 & & \\
\hline & [0.025] & & \\
\hline \multirow[t]{2}{*}{$D_{\text {capUtilDecHM }}(\mathrm{d})$} & & 0.0559 & \\
\hline & & {$[0.049]$} & \\
\hline \multirow[t]{2}{*}{$D_{\text {capUtilIncHM }}(\mathrm{d})$} & & & 0.0242 \\
\hline & & & {$[0.025]$} \\
\hline Obs & 1581 & 1581 & 1581 \\
\hline Pseudo $-R^{2}$ & 0.21 & 0.21 & 0.21 \\
\hline Log-likelihood & -729.6 & -729.3 & -729.5 \\
\hline \multicolumn{4}{|c|}{ 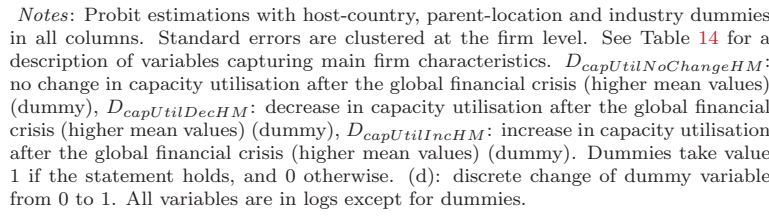 } \\
\hline
\end{tabular}


Table B18: Financial crisis effect: change in capacity utilisation with $10 \%$ tolerance

\begin{tabular}{|c|c|c|c|}
\hline 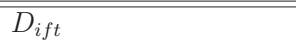 & (1) & 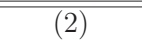 & 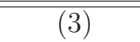 \\
\hline \multirow[t]{2}{*}{ skillInt } & -0.0153 & -0.0150 & -0.0153 \\
\hline & {$[0.014]$} & {$[0.014]$} & {$[0.014]$} \\
\hline \multirow[t]{2}{*}{ capInt } & -0.00580 & -0.00588 & -0.00599 \\
\hline & {$[0.0077]$} & {$[0.0077]$} & {$[0.0077]$} \\
\hline numEmp & $\begin{array}{c}0.0476^{* * *} \\
{[0.010]}\end{array}$ & $\begin{array}{c}0.0478^{* * *} \\
{[0.010]}\end{array}$ & $\begin{array}{c}0.0476^{* * *} \\
{[0.010]}\end{array}$ \\
\hline wageEmp & $\begin{array}{l}0.0170 \\
{[0.012]}\end{array}$ & $\begin{array}{l}0.0173 \\
{[0.012]}\end{array}$ & $\begin{array}{l}0.0171 \\
{[0.012]}\end{array}$ \\
\hline labProd & $\begin{array}{c}0.0332^{* * *} * \\
{[0.0099]}\end{array}$ & $\begin{array}{c}0.0335^{* * *} * \\
{[0.0099]}\end{array}$ & $\begin{array}{c}0.0331^{* * * *} \\
{[0.0099]}\end{array}$ \\
\hline inpInt & $\begin{array}{l}0.00442 \\
{[0.0080]}\end{array}$ & $\begin{array}{l}0.00421 \\
{[0.0080]}\end{array}$ & $\begin{array}{l}0.00459 \\
{[0.0080]}\end{array}$ \\
\hline$D_{\text {training }}(\mathrm{d})$ & $\begin{array}{l}0.0219 \\
{[0.023]}\end{array}$ & $\begin{array}{l}0.0221 \\
{[0.023]}\end{array}$ & $\begin{array}{l}0.0218 \\
{[0.023]}\end{array}$ \\
\hline$D_{\text {capUtilNoChange10T }}(\mathrm{d})$ & $\begin{array}{c}0.000141 \\
{[0.025]}\end{array}$ & & \\
\hline$D_{\text {capUtilDec10T }}(\mathrm{d})$ & & $\begin{array}{l}0.0165 \\
{[0.025]}\end{array}$ & \\
\hline$D_{\text {capUtilInc10T }}(\mathrm{d})$ & & & $\begin{array}{l}0.0218 \\
{[0.057]}\end{array}$ \\
\hline Obs & 1581 & 1581 & 1581 \\
\hline Pseudo $-R^{2}$ & 0.20 & 0.21 & 0.21 \\
\hline Log-likelihood & -730.0 & -729.8 & -730.0 \\
\hline $\begin{array}{l}\text { Notes: Probit estimations with } \\
\text { in all columns. Standard errors } \\
\text { description of variables capturin } \\
\text { no change in capacity utilisati } \\
\text { (cummy), DapUtilDec10T: decr } \\
\text { crisis }(10 \% \text { tolerance) (dummy), } \\
\text { the global financial crisis }(10 \% \\
\text { tatement holds, and } 0 \text { otherwis } \\
\text { t. All variables are in logs exce }\end{array}$ & try, & $\begin{array}{l}\text { cation and } \\
\text { m level. } \\
\text { stics. } D_{C a} \\
\text { incial cris } \\
\text { ion after } \\
\text { se in capac } \\
\text { ummies }\end{array}$ & $\begin{array}{l}\text { try dummies } \\
\text { able } 14 \text { for a } \\
\text { ochange } 10 T: \\
\% \text { tolerance) } \\
\text { obal financial } \\
\text { ilisation after } \\
\text { value } 1 \text { if the }\end{array}$ \\
\hline
\end{tabular}


Table B19: Financial crisis effect: change in capacity utilisation with $20 \%$ tolerance

\begin{tabular}{|c|c|c|c|}
\hline $\bar{D}_{\text {ift }}$ & (1) & (2) & (3) \\
\hline skillInt & $\begin{array}{c}-0.0155 \\
{[0.014]}\end{array}$ & $\begin{array}{l}-0.0151 \\
{[0.014]}\end{array}$ & $\begin{array}{c}-0.0152 \\
{[0.014]}\end{array}$ \\
\hline capInt & $\begin{array}{c}-0.00582 \\
{[0.0077]}\end{array}$ & $\begin{array}{c}-0.00594 \\
{[0.0077]}\end{array}$ & $\begin{array}{c}-0.00593 \\
{[0.0077]}\end{array}$ \\
\hline numEmp & $\begin{array}{c}0.0479 * * * \\
{[0.010]}\end{array}$ & $\begin{array}{c}0.0483^{* * *} \\
{[0.010]}\end{array}$ & $\begin{array}{c}0.0476^{* * *} \\
{[0.010]}\end{array}$ \\
\hline wageEmp & $\begin{array}{l}0.0174 \\
{[0.012]}\end{array}$ & $\begin{array}{l}0.0177 \\
{[0.012]}\end{array}$ & $\begin{array}{l}0.0173 \\
{[0.012]}\end{array}$ \\
\hline labProd & $\begin{array}{c}0.0331^{* * *} \\
{[0.0099]}\end{array}$ & $\begin{array}{c}0.0334^{* * *} \\
{[0.0099]}\end{array}$ & $\begin{array}{c}0.0330^{* * *} \\
{[0.0099]}\end{array}$ \\
\hline inpInt & $\begin{array}{l}0.00468 \\
{[0.0080]}\end{array}$ & $\begin{array}{l}0.00449 \\
{[0.0080]}\end{array}$ & $\begin{array}{l}0.00447 \\
{[0.0080]}\end{array}$ \\
\hline$D_{\text {training }}(\mathrm{d})$ & $\begin{array}{l}0.0218 \\
{[0.023]}\end{array}$ & $\begin{array}{l}0.0222 \\
{[0.023]}\end{array}$ & $\begin{array}{l}0.0214 \\
{[0.023]}\end{array}$ \\
\hline$D_{\text {capUtilNoChange } 20 T}(\mathrm{~d})$ & $\begin{array}{c}-0.0162 \\
{[0.026]}\end{array}$ & & \\
\hline$D_{\text {capUtilDec } 20 T}(\mathrm{~d})$ & & $\begin{array}{l}0.0379 \\
{[0.028]}\end{array}$ & \\
\hline$D_{\text {capUtilInc } 20 T}(\mathrm{~d})$ & & & $\begin{array}{l}0.0397 \\
{[0.080]}\end{array}$ \\
\hline Obs & 1581 & 1581 & 1581 \\
\hline Pseudo- $R^{2}$ & 0.21 & 0.21 & 0.21 \\
\hline Log-likelihood & -729.8 & -729.1 & -729.9 \\
\hline $\begin{array}{l}\text { Notes: Probit estimations with } \\
\text { in all columns. Standard errors } \\
\text { description of variables capturin } \\
\text { no change in capacity utilisati } \\
\text { (cummy), DapUtilDec20T: decr } \\
\text { crisis (20\% tolerance) (dummy), } \\
\text { the global financial crisis (20\% } \\
\text { tatement holds, and } 0 \text { otherwis } \\
\text { t. All variables are in logs exce }\end{array}$ & $\begin{array}{l}\mathrm{n} \text { firm cha } \\
\text { er the glot } \\
\text { a capacity } \\
\text { tillnc20T: } \\
\text { nce) (dum } \\
\text { discrete c } \\
\text { dummies. }\end{array}$ & $\begin{array}{l}\text { cation an } \\
\text { irm level. } \\
\text { istics. } D \text {, } \\
\text { ancial cr } \\
\text { tion after } \\
\text { ise in cape } \\
\text { Dummies } \\
\text { of dumm }\end{array}$ & $\begin{array}{l}\text { stry dummies } \\
\text { able } 14 \text { for a } \\
\text { voChangencoT: } \\
\% \text { tolerance) } \\
\text { obal financial } \\
\text { ilisation after } \\
\text { ralue } 1 \text { if the } \\
\text { ble from } 0 \text { to }\end{array}$ \\
\hline
\end{tabular}


Table B20: Financial crisis effect: change in capacity utilisation with $30 \%$ tolerance

\begin{tabular}{|c|c|c|c|}
\hline \multirow{3}{*}{$\begin{array}{l}D_{\text {ift }} \\
\text { skillInt }\end{array}$} & (1) & (2) & $(3)$ \\
\hline & -0.0149 & -0.0153 & -0.0152 \\
\hline & {$[0.014]$} & {$[0.014]$} & {$[0.014]$} \\
\hline \multirow[t]{2}{*}{ capInt } & -0.00579 & -0.00583 & -0.00577 \\
\hline & {$[0.0077]$} & {$[0.0077]$} & {$[0.0077]$} \\
\hline numEmp & $\begin{array}{c}0.0473^{* * *} \\
{[0.010]}\end{array}$ & $\begin{array}{c}0.0476^{* * *} \\
{[0.010]}\end{array}$ & $\begin{array}{c}0.0475^{* * *} \\
{[0.010]}\end{array}$ \\
\hline wage Emp & $\begin{array}{l}0.0169 \\
{[0.012]}\end{array}$ & $\begin{array}{l}0.0171 \\
{[0.012]}\end{array}$ & $\begin{array}{l}0.0174 \\
{[0.012]}\end{array}$ \\
\hline labProd & $\begin{array}{c}0.0334^{* * *} \\
{[0.0099]}\end{array}$ & $\begin{array}{c}0.0332 * * * \\
{[0.0099]}\end{array}$ & $\begin{array}{c}0.0331^{* * *} \\
{[0.0099]}\end{array}$ \\
\hline inpInt & $\begin{array}{l}0.00417 \\
{[0.0080]}\end{array}$ & $\begin{array}{l}0.00441 \\
{[0.0080]}\end{array}$ & $\begin{array}{l}0.00454 \\
{[0.0080]}\end{array}$ \\
\hline$D_{\text {training }}(\mathrm{d})$ & $\begin{array}{l}0.0214 \\
{[0.023]}\end{array}$ & $\begin{array}{l}0.0220 \\
{[0.023]}\end{array}$ & $\begin{array}{l}0.0209 \\
{[0.023]}\end{array}$ \\
\hline$D_{\text {capUtilNoChange } 30 T}$ (d) & $\begin{array}{l}0.0217 \\
{[0.030]}\end{array}$ & & \\
\hline$D_{\text {capUtilDec30T }}(\mathrm{d})$ & & $\begin{array}{c}0.00422 \\
{[0.036]}\end{array}$ & \\
\hline$D_{\text {capUtilInc } 30 T}(\mathrm{~d})$ & & & $\begin{array}{c}0.0908 \\
{[0.14]}\end{array}$ \\
\hline Obs & 1581 & 1581 & 1581 \\
\hline Pseudo $-R^{2}$ & 0.21 & 0.20 & 0.21 \\
\hline Log-likelihood & -729.8 & -730.0 & -729.7 \\
\hline
\end{tabular}

Notes: Probit estimations with host-country, parent-location and industry dummies in all columns. Standard errors are clustered at the firm level. See Table 14 for a description of variables capturing main firm characteristics. D capUtilNoChange30T: no change in capacity utilisation after the global financial crisis (30\% tolerance) (dummy), $D_{\text {capUtilDec30T: }}$ decrease in capacity utilisation after the global financial

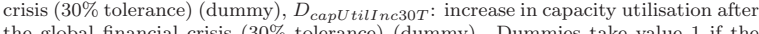
the global financial crisis ( $30 \%$ tolerance) (dummy). Dummies take value 1 if the statement holds, and 0 otherwise. (d): discrete change of dummy variable from 0 to All variables are in logs except for dummies. 
Table B21: Productivity and size premia of foreign affiliates with arms' length trade over domestic firms with arms' length trade (Manufacturing sector)

\begin{tabular}{|c|c|c|c|c|c|}
\hline \multicolumn{6}{|c|}{ Panel A: Foreign affiliates with arms' length trade } \\
\hline & (1) & $(2)$ & (3) & (4) & (5) \\
\hline & Productivity & Size & Productivity & Size & Productivity \\
\hline & $0.0875^{*}$ & $0.328^{* * *}$ & $0.212^{* * *}$ & $0.436^{* * *}$ & 0.0359 \\
\hline & {$[0.051]$} & {$[0.060]$} & {$[0.078]$} & {$[0.082]$} & {$[0.052]$} \\
\hline \multirow[t]{2}{*}{$D_{\text {fnotrade }}$} & 0.0207 & -0.0827 & 0.115 & -0.0704 & -0.0561 \\
\hline & {$[0.082]$} & [0.093] & {$[0.13]$} & {$[0.14]$} & {$[0.090]$} \\
\hline \multirow{2}{*}{$D_{\text {nofnotrade }}$} & $-0.236 * * *$ & $-0.613^{* * *}$ & $-0.219^{* * *}$ & $-0.886^{* * *}$ & $-0.200 * * *$ \\
\hline & {$[0.068]$} & {$[0.056]$} & {$[0.084]$} & {$[0.089]$} & {$[0.060]$} \\
\hline Obs & 2372 & 2381 & 2062 & 2372 & 2349 \\
\hline \multicolumn{6}{|c|}{ Panel B: Foreign affiliates with different arms' length trade flows } \\
\hline \multirow{4}{*}{$D_{\text {fimponly }}$} & $(1)$ & $(2)$ & $(3)$ & $(4)$ & $(5)$ \\
\hline & Productivity & Size & Productivity & Size & Productivity \\
\hline & 0.0911 & 0.0600 & $0.316^{* * *}$ & 0.149 & 0.0310 \\
\hline & {$[0.061]$} & {$[0.068]$} & {$[0.092]$} & [0.098] & {$[0.067]$} \\
\hline \multirow[t]{2}{*}{$D_{\text {fexponly }}$} & 0.0277 & 0.224 & $0.361 * *$ & 0.288 & $0.165^{*}$ \\
\hline & {$[0.13]$} & {$[0.14]$} & {$[0.14]$} & {$[0.20]$} & {$[0.100]$} \\
\hline \multirow[t]{2}{*}{$D_{\text {fimpexp }}$} & 0.101 & $0.712^{* * *}$ & 0.0247 & $0.856^{* * *}$ & 0.00181 \\
\hline & {$[0.078]$} & {$[0.087]$} & {$[0.12]$} & {$[0.12]$} & {$[0.075]$} \\
\hline \multirow[t]{2}{*}{$D_{\text {fnotrade }}$} & 0.0203 & -0.0772 & 0.113 & -0.0646 & -0.0553 \\
\hline & {$[0.082]$} & {$[0.093]$} & {$[0.13]$} & {$[0.14]$} & {$[0.090]$} \\
\hline \multirow[t]{2}{*}{$D_{\text {nofnotrade }}$} & $-0.236 * * *$ & $-0.614^{* * *}$ & $-0.211^{* *}$ & $-0.888^{* * *}$ & $-0.198 * * *$ \\
\hline & {$[0.068]$} & {$[0.056]$} & {$[0.084]$} & {$[0.089]$} & {$[0.060]$} \\
\hline Obs & 2372 & 2381 & 2062 & 2372 & 2349 \\
\hline \multicolumn{6}{|c|}{$\begin{array}{l}\text { Notes: OLS estimations with control variables in both panels and all columns: skill intensity, capital intensity, } \\
\text { input intensity, total employment, host-country, parent-location and industry dummies. Firm size regressions omit } \\
\text { the log of total employment as a covariate. Standard errors are clustered at the firm level. Productivity (column } 1) \text { : }\end{array}$} \\
\hline
\end{tabular}

Table B22: Productivity and size premia of foreign affiliates with trade, both intra-firm and arms' length trade and arms' length trade only (Manufacturing sector)

\begin{tabular}{|c|c|c|c|c|c|}
\hline \multicolumn{6}{|c|}{ Panel A: Foreign affiliates with trade } \\
\hline \multirow{4}{*}{$D_{\text {trade }}$} & (1) & $(2)$ & $(3)$ & (4) & $(5)$ \\
\hline & Productivity & Size & Productivity & Size & Productivity \\
\hline & 0.171 & $0.504^{* * *}$ & $0.331^{* *}$ & $0.695^{* * *}$ & $0.195^{*}$ \\
\hline & {$[0.11]$} & {$[0.11]$} & {$[0.16]$} & {$[0.16]$} & {$[0.12]$} \\
\hline Obs & 961 & 963 & 835 & 961 & 957 \\
\hline \multicolumn{6}{|c|}{ Panel B: Foreign affiliates with different trade flows } \\
\hline \multirow{4}{*}{$D_{\text {imponly }}$} & $(1)$ & $(2)$ & $(3)$ & $(4)$ & $(5)$ \\
\hline & Productivity & Size & Productivity & Size & Productivity \\
\hline & 0.109 & $0.249^{* *}$ & $0.307^{*}$ & $0.361^{* *}$ & 0.104 \\
\hline & {$[0.12]$} & {$[0.11]$} & {$[0.17]$} & {$[0.18]$} & {$[0.12]$} \\
\hline \multirow[t]{2}{*}{$D_{\text {exponly }}$} & 0.198 & $0.422^{* * *}$ & $0.463^{* *}$ & $0.647^{* * *}$ & $0.373^{* * *}$ \\
\hline & {$[0.16]$} & {$[0.14]$} & {$[0.21]$} & {$[0.21]$} & {$[0.14]$} \\
\hline \multirow[t]{2}{*}{$D_{\text {impexp }}$} & $0.243^{* *}$ & $0.795^{* * *}$ & $0.315^{*}$ & $1.060 * * *$ & $0.255^{* *}$ \\
\hline & {$[0.12]$} & {$[0.12]$} & {$[0.18]$} & {$[0.18]$} & {$[0.13]$} \\
\hline Obs & 961 & 963 & 835 & 961 & 957 \\
\hline \multicolumn{6}{|c|}{$\begin{array}{l}\text { Notes: OLS estimations with control variables in all panels and all columns: skill intensity, capital intensity, } \\
\text { input intensity, total employment, host-country, parent-location and industry dummies. Firm size regressions } \\
\text { omit the log of total employment as a covariate. Standard errors are clustered at the firm level. Productivity } \\
\text { (column 1): log of the ratio of total sales to total employment. Size (column 2): total employment. Produ- } \\
\text { tivity (column 3): log of the ratio of value added to total employment. Size (column 4): log of total sales. } \\
\text { Productivity (column 5): log of total factor productivity. Panel A: } D_{\text {trade }} \text { : firm has imports or exports, or } \\
\text { both (dummy). Panel B: } D_{\text {import }} \text { : firm has imports only (dummy), Dexport : firm has exports only (dummy), } \\
D_{\text {impexp }} \text { : firm has both imports and exports (dummy). Dummies take value } 1 \text { if statement holds, and } 0 \\
\text { otherwise. All variables are in logs except for dummies. }\end{array}$} \\
\hline
\end{tabular}

